KS. BOLESEAW KUMOR

\title{
PREPOZYTURA TARNOWSKA
}

OPRACOWANIE MATERIAŁÓW ZRÓDŁOWYCH DO ATLASU HISTORYCZNEGO KOŚCIOEA W POLSCE 


\section{PRZEDMOWA}

Praca niniejsza zgodnie z przyjętymi założeniami w rozprawie Archidiakonat saqdecki ${ }^{1}$ podaje schematyczny opis wszystkich instytucji o charakterze społeczno-kościelnym, istniejących $w$ granicach parafii łacińskich na terenie prepozytury tarnowskiej. Zagadnienie początku i rozwoju samej prepozytury, oficjałatu okręgowego i dekanatu tarnowskiego zostanie przedstawione w rozdziale wstępnym.

Zakres czasowy pracy sięga górnej granicy początków każdej $\mathrm{z}$ omawianych instytucji. W wypadku niektórych parafii będzie to w. XII. Dolną natomiast cezurę opracowania stanowi pierwszy rozbiór Polski (1772) i przejście prepozytury pod panowanie austriackie, a nade wszystko erekcja 13 III 1786 diecezji tarnowskiej ${ }^{2}$, odkąd na wspomnianym terenie zaczęło się formować zupełnie inne życie religijne, niż to miało miejsce $w$ przedrozbiorowym okresie diecezji krakowskiej. Trzeba jednakże zaznaczyć, że nie rzadko granica dolna została przesunięta do końca w. XVIII, a nawet dalej, atoli przesunięcia te dotyczą takich instytucji jak kościoły, klasztory, kaplice, kolegia, prebendy, altarie, szpitale, szkoły, Iudność parafii itp. W żadnym natomiast wypadku nie dotyczy to organizacji terytorialnej (prepozytura, oficjałat, dekanat, parafie) ze względu na tak zwaną regulację józefińską (1784). Odnośnie do bractw kościelnych należy zaznaczyć, że dolna ich granice stanowi r. 1783, kiedy to dekret ces. Józefa II (22 V 1783) zniósł wszystkie tego rodzaju instytucje, a w ich miejsce polecał tworzyć ,bractwa czynnej miłości bliźniego" 3 . Dolną natomiast cezure dla tzw. beneficjów prostych (kolegia wikariuszy, mansjonarzy, psałterzystów, prepozytury szpitalne, altarie, prebendy) ustanowił dekret tegoż cesarza z 28 II 1782, tworzący fundusz religijny, na który przeznaczono dobra i kapitały zniesionych klasztorów oraz wspomnianych beneficjów ${ }^{4}$.

W zakres rzeczowy opracowania weszly przede wszystkim instytucje Kościoła rzymsko-katolickiego, omówione szczegółowo niżej, a nadto instytucje kościołów protestanckich i religii mojżeszowej, ale w ramach parafii lacińskich. Instytucji Kościoła wschodniego, zarówno katolickiego jak i prawosławnego, w granicach prepozytury tarnowskiej nie było żadnych. Za-

$1 \mathrm{Ks}$. B. K $\mathrm{K}$ m $\mathrm{r}$ Archıdiakonat sądeckı. Opracowanie materiałów źródłowych do Atlasu historycznego Kościola w Polsce. Arch. Bibliot. kośc. T. 8: 1964 s. 271-304; t. 9: 1964 S. $93-286$.

2 Ks. B. K u m or Dzieje polityczno-geograficzne diecezji tarnowskiej. Lublin 1958 (Katolicki Uniwersytet Lubelski. Rozprawy Doktorskie, Magisterskie i Seminaryjne. Wydziat Teologiczny. T. 8) s. 36.

3 Por. E. Tom e k: Kirchengeschichte Ósterreichs. Th. 3. Innsbruck 1959 s. $469 . \quad-$ W. M. Plö chl: Geschichte des Kirchenrechts. Bd 3: Das katholische Kirchenrecht der Neuzeit. Th. 1. Wien 1959 s. 481 . - E. W 1 nter: Der Josefinismus und seine Geschichte. Brün 1943 s. 244.

4 E. Tom ek, jw. s. 386. - w. P. Plö h l, jw. s. 309. - E. Winter. jw. s. 174. 
kres terytorialny pracy obejmuje tylko prepozyturę tarnowską i to w granicach wykreślonych przez synod diecezjalny krakowski z r. $1711^{5}$.

Podstawa źródłowa Prepozytury została oparta nade wszystko na źródłach archiwów kościelnych (Archiwum Kurii Metropolitalnej w Krakowie; Archiwum Diecezjalne w Tarnowie; Archiwum Kapituły Katedralnej w Tarnowie; poszczególne archiwa parafialne) i państwowych (Wojew. Archiwum Państwowe w Krakowie; Muzeum miasta Tarnowa; Zakład Narodowy im. Ossolińskich we Wrocławiu). Do ważniejszych zespołów i serii archiwalnych należały wizytacje kościelne (1565-1814), księgi czynności biskupów (XV-XVIII w.), księgi czynności oficjałów generalnych i okręgowych (XVXVIII w.), księgi beneficjów retaksowanych, księgi brackie, dyplomy pergaminowe (dotyczące najczęściej bractw i cechów), kopiarze i inwentarze kolegiackie, parafialne i klasztorne, materiał aktowy itp.

Do wykorzystanych źródeł drukowanych należą m. in. rejestry świętopietrza $i$ dziesięciny papieskiej z lat 1325-1562, wydane przez. J. Ptaśnika i ks. T. Grommickiego, księgi beneficjów diecezji krakowskiej, opracowane przez J. Dlugosza ( $\mathrm{XV}$ w.), materiały dokumentowe, zawarte w kodeksach dyplomatycznych 1 innych publikacjach, rejestry poborowe, synodalne wykazy parafii itd.

Zebrane źródła podzielono na dwie grupy: 1) „Źródła przekrojowe” to te, które odnoszą się do każdej parafii i powtarzają się co kilka, względnie kilkanaście lat, np. rejestry świętopietrza, księgi beneficjów Długosza, księgi beneficjów retaksowanych, rejestry poborowe, akta wizytacyjne itp. Odnolowano je na początku każdego opisu schematycznego parafii. W wypadku przekrojowych informacji źródeł tych nie cytowano juz $w$ przypisach. 2) W rubryce „Inne źródła” zamieszczano te przekazy rękopiśmienne, które nie zostały wymienione $w$,źródłach przekrojowych”. Były to najczęściej archiwalia diecezjalne tarnowskie, poszczególnych parafii, czy też zaczerpnięte $z$ archiwów państwowych. Wykorzystane opracowania najczęściej zostały umieszczone w przypisach. Główniejsze z nich zamieszczono w rubryce „Ważniejsze opracowania”.

Schemat opisu każdej parafii, obejmujący 14 elementów, jest identyczny $\mathrm{z}$ zastosowanym w Archidiakonacie sadeck ${ }^{6}{ }^{6}$. Oto jego elementy składowe: A. Dzieje instytucji. Patronat. B. Obszar parafii. C. Liczba ludności. D. Swiątynja parafialna. E. Inne świątynie. F. Szpital i kościół szpitalny. G. Organizacje wiernych: bractwa, cechy. H. Szkoły, liczba uczniów. J. Pielgrzymki. K. Misje. L. Kolegiaty i kolegia. M. Prebendy i altarie. N. Inne (np. laskami słynące obrazy) ${ }^{7}$. Cyfry lacińskie oznaczają: I - instytucje Kościoła katolickiego; V - instytucje kościołów protestanckich; VI - instytucje religii mojżeszowej.

Całość pracy składa się $\mathrm{z}$ dwóch rozdziałów; pierwszy omawia organizacje prepozytury wyższego rzędu, jak: początki, granice i rozwój terytorialny prepozytury, oficjałatu $i$ dekanatu tarnowskiego do r. 1772 czyli do pierwszego rozbioru Polski, a właściwie do r. 1786 tj. do utworzenia die-

5 Synodus dioecesana ab ill. rev. d. Casımiro a Eubna Eubieński, ep. Crac. celebrata Cracoviae 1711. Cracoviae 1711 s. 15.

6 Por. ks. B. K u m or: Archidiakonat s. $273 \mathrm{n}$.

7 Por, Z. Sułowskl: Z zycia Instytutu Geografil Historycznej Kościola w Polsce. Wydawnictwo "Polonia Christiana". Rocz-l human. T. 9: 1960 z. 4 s. 5-12. - Zob. B. K u mo r: Archidiakonat s. $273 \mathrm{n}$. 
cezji tarnowskiej. Rozdział ten poprzedza wylkaz skrótów, używanych w niniejszym opracowaniu.

Rozdział drugi, stanowiący istotną część rozprawy, obejmuje schematyczny opis parafii w porządku alfabetycznym, a w ich granicach — także instytucji religijnych. Całość pracy zawiera 23 parafie, istniejące od XI do XVIII w. w granicach prepozytury, z których 2 zupełnie zanikły (Tarnów św. Marcin; Tarnów - s. Mariae in castro), a 5 przez dłuższy lub krótszy okres czasu istniało w formie "wikarii wieczystej" (Wierzchosławice, Skrzyszów, Łękawica, Zalasowa, Poręba Radlna). Jeden z kościołów parafialnych (Tarnów - parafia Narodzenia NMP) został w r. 1400 wyniesiony do godności kolegiaty, która przetrwała cały omawiany okres jako największa z kolegiat diecezji krakowskiej po wschodniej stronie Wisły.

Odnośnie „obszaru parafii’ nalezy stwierdzić, że największą terytorialnie parafią pod koniec XVI w. (1581/96) był Tarnów, obejmujacy, oprócz miasta 15 wsi; w połowie XVIII w. najwięlzszą była parafia Lisia Góra. W granicach tej parafii w r. 1748 wymieniono aż 20 wsi. W następnej kolejności pod koniec XVI w. idą parafie: Jurków, Lisia Góra (12 wsi), Zassów (10), Góra Zbylitowska i Tuchów (9), Pleśna, Jodłówka (7), Dąbrowa, Poręba Radlna, Wierzchosławice i Ryglice (6), Piotrkowice (5), Skrzyszów i Zdziarzec (4), Eękawica (2) i trzy parafie jednowioskowe (Jastrząbka, Szynwałd, Zalasowa).

Najludniejszą parafią poza Tarnowem, w polowie XVIII w. (1754) okazała się Lisia Góra (3400), a następnie Dąbrowa Tarnowska (3000), Zassów (2433) i Jurków (2000); najuboższe natomiast w ludność były parafie: Jastrząbka (200), Piotrkowice (340) i Łękawica (400).

$\mathrm{Na} 19$ kościołów parafialnych w r. 1596 były tylko dwa murowane (Tarnów i Łękawica), jeden częściowo murowany (Góra Zbylitowska), pozostałe zaś 16 parafii posiadało kościoły drewniane. Do r. 1748 wybudowano dwa dalsze kościoły murowane (Lisia Góra i Tuchów).

W r. 1748 , na 21 parafii, tylko 9 posiadało kościoły filialne i kaplice mszalne. Na czoło wysunął się pod tym względem Tarnów (9), a w dalszej kolejności szły: Tuchów (7), Dąbrowa (5), Góra Zbylitowska i Jurków (3), Pleśna, Piotrkowice, Skrzyszów i Zassów (po 1). Daleko lepiej przedstawiała się sieć szpitalnictwa parafialnegọ. Poza dwiema (Pleśna i Zalasowa) wiszystkie parafie posiadały własne szpitale.

Spośród bractw kościelnych, istniejących przy poszczególnych kościołach parafialnych dekanatu, należy wymienić następujące: Różańca św., Ubogich, Literackie NMP, Aniołów Stróżów, Trójcy Przenajśw., Sw. Jana Nepomucena, św. Józefa Obl. NMP, św. Eazarza, Niepokalanego Poczęcia NMP, Opieki św. Józefa, Szkaplerza św., św. Anny, Bożego Ciała, św. Franciszka, św. Antoniego z Padwy i M. B. Pocieszenia. Nie posiadały żadnych bractw parafie: Jodłówka Szczepanowska, Pleśna, Radgoszcz, Zalasowa, Zdziarzec.

Szkolnictwo parafialne pod koniec XVI i na początku XVII w. objęlo wszystkie parafie. Sytuacja zmieniła się na gorsze w połowie XVIII w. Na 21 parafii tylko odnośnie dziesięciu są wtenczas przekazy zródłowe o istnieniu szkoły parafialnej (Dąbrowa, Jurków, Lisia Góra, Ryglice, Skrzyszów, Szynwald, Tarnów, Tuchów i Zassów). Oprócz tego w Tarnowie, przy kolegiacie istniała kolonia akademicka, a przy klasztorze bernardyńskim studium filozoficzne. 
Przekazy o pielgrzymkach, z okazji wielkich odpustów, odnotowano tylko w dwóch wypadkach (Tarnów i Tuchów); „łaskami słynące obrazy" wspomniano w Piotrkowicach, Ryglicach, Tuchowie i Zassowie. O misjach nie napotkano żadnej wzmianki.

Kolegia duchownych, oparte o własny statut, istniały tylko przy kolegiacie tarnowskiej. Były to kolegia: prałatów i kanonilków (kapituła większa), wikariuszów (kapituła mniejsza), mansjonarzy i psał.terzystów. Prebendy i altarie były instytucjami dość częstymi. Najwięcej posiadała ich kolegiata tarnowska (14). Nie posiadały ich parafie: Jodłówka, Łękawica, Pleśna, Poręba Radlna, Radgoszcz, Zalasowa i Zdziarzec.

$\mathrm{Z}$ instytucji innych wyznań chrześcijańskich i religii mojżeszowej na terenie dekanatu istniały, krócej lub dłużej, w omawianym okresie 2 zbory protestanckie (Góra Zbylitowska i Jodłówka), 2 synagogi żydowskie (Dąbrowa i Tarnów) oraz 1 szkoła protestancka (Szczepanowice).

$\mathrm{Na}$ tym miejscu pragnę serdecznie podziękować Dyrekcjom archiwów oraz bibliotek państwowych i kościelnych za udostępnienie mi zbiorów a Redakcji Archiwów za umieszczenie Prepozytury na łamach swego półrocznika.

\section{BIBLIOGRAFIA ZAEACZNIKOWA I SKRÓTY}

AAdm.

ADT

AEp

AGZ

AKapMIK

AKapSand.

AKapT

AKMK

AOffic.

APar.

APBern.

ASang.

BAV

Bibl. Ossol.

SDIMP

CDPol.

CDT
- Acta administratoria dioecesis Cracoviensis. (Archiwum Kurii Metropolitalnej w Krakowie).

- Archiwum Diecezjalne w Tannowie.

- Acta episcopalia dioecesis Cracoviensis. (Archiwum Kuriu Metropolitalnej w Krakowie).

- Akta grodzkie i ziemskie z czasów Rzeczypospolitej Polskiej $z$ Archiwum tak zwanego Bernardyńskiego we Lwowie... Wyd. O. Pietruski, L. Tatomir, X. Liske i in. T. 1-25. Lwów 1868-1935.

- Archiwum Kapituły Metropolitalnej w Krakowie.

- Archiwum Kapituły Katedralnej w Sandomierzu.

- Archiwum Kapituły Katedralnej w Tarnowie.

- Archiwum Kurii Metropolitalnej w Krakowie.

- Acta Officialatus generalis dioecesis Cracoviensis. (Archiwum Kurii Metropolitalnej w Krakowie).

- Archiwum parafialne.

- Archiwum Prowincji OO. Bernardynów w Krakowie.

- Archiwum Książąt Lubartowiczów-Sanguszków w Sławucie. Wyd. E. L. Radzimiński, P. Skobielski, B. Gorc z a k. T. 2, 5. Lwów 1888, 1897.

- Bibliotheca Apostolica Vaticana.

- Biblioteka Zakładu Narodowego im. Ossolińskich we Wroclawiu.

-. Codex diplomaticus Poloniae Minoris 1178-1457. Ed. F. Pi ekosiński T. 1-4. Kraków 1876-1905. (Monumenta medii aevi historica. T. 3, 9-10, 17).

- Codex diplomaticus Poloniae... T. 3. Ed. J. B a rt os z ewi cz. Varsaviae 1858.

- Codex diplomaticus monasterii Tinecensis 1105-1506. Ed. W. K ętrzyński, S. S molk a. Lwów 1875.

Elenchus omnium - Elenchus omnium parochiarum erigendam novam dioecesim parochiarum 1785 Tarnoviensem constituentium 1785. W: Processus inquisitionis super statu ecclesiae Tarnoviensis, nunc primum aucto- 
ritate apostolica in cathedralem erigendae, et super qualitatibus rev. anı Joannis Duwal, praeposit, ecclesiae collegiatae Voinicensis et vicarii generalis dioecesis Cracoviensis in parte Austriaca ad eprscopatum Tarnoviensem dicta auctoritate promovendi et nominati 1785. Bíbliotheca Apostolica Vaticana. Vol. 187 k. $303-314 \mathrm{v}$

Gromnicki: Świę- - Ks. T. Grom ni cki: Swiętopietrze w Polsce. Kraków 1908. topietrze

Hirschiberg: Stosuniki osadnicze

Katalog inwentarzy

KDKK

Kot: Szkolnictwo

Krasiński: Zarys

Krasinski: Zarys -

Krzepela: Księga - J. K r ze pela: Księga rozsiedlenia rodów ziemiańskich rozsiedlenia

Kumor: Archidia- konat

Kumor: Dzieje

Kumor: Falsysyfikaty

Kumor: Powstanie i rozwój sieci

Kumor: Zamik i afiliacja

LBD

LR 1513

LR 1527

LR 1529

A. Hirsch ber g: Stosunki osadnicze w dobrach klasztoru tynieckıego w początkach jego istnienia. Lwów 1925.

- Katalog inwentarzy dóbr ziemskich XVI-XVIII wieku sporządzony na podstawie ksiąg grodzkich i ziemskich. Oprac. pod red. W. M a ciejewskiej H. Karczowa, W. Maciejewska, R. Piechota. Warszawa 1959.

- Kodeks dyplomatyczny katedry krakowskiej św. Waclawa. Wyd. F. Piekosiński. T. 1-2. Kraków 1874-1882. (Monumenta medii aevi historica. T. 1, 8).

- S. K ot: Szkolnictwo parafialne w Małopolsce XVI-XVIII w. Lwów 1912. (Odb. z Muzeum).

W. K r asiński: Zarys dziejów powstania i upadku reformacji w Polsce. Wyd. J. Bursche. T. 1-2. Warszawa $1903-1905$ w dobie Jagiellońskiej. Cz. 1: Malopolska. T. 1. Kraków 1915 Ks. B. K u m or: Archidiakonat sądecki. Opracowanie materiałów źródłowych do Ațlasu historycznego Kościoła w Polsce. Arch. Bibliot. kośc. T. 8: 1964 s. 271-304; t. 9: 1964 s. $93-286$

- Ks. B. K u mor: Dzieje polityczno-geograficzne diecezji tarnowskiej. Lublin 1958. (Katolicki Uniwersytet Lubelski. Rozprawy Doktorskie, Magisterskie i Seminaryjne. Wydziat Teologiczny. T. 8).

- Ks. B. K u m o r: Nieznane falsy fikaty S. Morawskiego. Małop. Studia hist. R. 2: 1959 z. 2/3 s. 114-121.

- Ks. B. K u mor: Powstanie i rozwój sieci parafialnej w Małopolsce Południowej do końca XVI w Prawo kanon. R. 5: 1962, $\mathrm{nr} 3 / 4$ s. $175-231$ : R. 6: 1963. $\mathrm{nr}$ 1/4 s. 441-534.

- Ks. B. Ku mor: Zanik i afiliacja parafii w archidiakonacie sądeckim, wojnickim i prepozyturze tarnowskiej (1326-1782). Rocz-i teol.-kanon. T. 9: 1964, z. 4 s. 87-134.

- J. Długosz: Liber beneficiorum dioecesis Cracoviensis. Cur. A. Przeździ e cki. T. 1-3. Cracoviae 1863-1864. (W: J. Dlugosz: Opera omnia. T. 7-9).

- Regestrum contributionis per unum fertonem a marca argenti ad clerum a. D. 1513. (Archiwum Kapituły Metropolitalnej w Krakowie).

- Regestrum contributionis personalis vicariorum perpetuorum, mansionariorum, psalteristarum, aliorumque omnium et singulorum presbiterorum, tam cathedralis quam parochialium ecclesiarum Cracoviae ac ceterorum decanatuum a. 1527. (Archiwum Kapituly Metropolitalnej w Krakowie).

- Liber benleficiorum retaxationum ex commissione r.d. Petri Tomicki - ep. Crac. ad cognoscendum verum valorem proventuum omnium ecclesiarum beneficiorum ecclesiasticorum in dioecesi Cracoviensi consistentium a. D. 1529 
LR 1539

conscriptus. (Archiwum Kapituły Metropolitalnej w Krakowie).

- Regestrum contributionis duplae iuxta taxam antiquam episcopatus et omnium beneficiorum dioecesis Cracoviensis ad an. 1539. (Archiwum Kapituły Metropolitalnej w Krakowie).

LR 1561

- Liber beneficiorum retaxationum a. 1561. (Archiwum Kapituły Metropolitainej w Kralkowie).

LR 1577

- Liber beneficiorum retaxationum a. 1577. (Archiwum Kapituły Metropolitalnej w Krakowie).

Eadogórski Studia - T. Eładogórski: Studia nad zaludnieniem Polski XIV w. Wroclaw 1958.

Merczyng: Zbory - [H. M erczyng] H. M.: Zbory i senatorowie protestanccy w dawnej Rzeczypospolitej. Warszawa 1904.

iMPV - Monumenta Poloniae Vaticana. T. 1-3. Ed. J. Ptaśnik. Cracoviae 1913-1914.

MRPS - T. Wi e r z bow ski: Matricularum Regni Poloniae summaria. P. 1-5. Warszawa 1905-1909.

Niwiński: Archi- - M. Niwiński: Archiwum konsystorza biskupiego w Tarwum nowie. Whocławek 1937. (Odb. z Aten. kapt. T. 40).

Officialia Branicki - Acta rev. d. Gasparis Braniczki praepositi perpetuique officialis Tarnoviensis - - ab an. 1599-1602. (Archiwum Kapituły Katedralnej w Tarnowie).

Officialia Kazimierski

Officialia Ziemięcki

Rej. pob. 1508

- Acta rev. d. Christophori $\mathrm{K}$ a zi mi e r s i praepositi perpetuique officialis Tarnoviensis $-\longrightarrow$ ab an. D. 1585-1599. (Archiwum Kapituly Katedralnej w Tarnowie).

- Acta perpetui officialatus Tarnoviensis a. D. 1602 sub felici eidem praesidentia adm. rev. d. Alberti $\mathrm{Ziemieczki}$, praepositi ac perpetui officialis Tarnoviensis. (Archiwum Kapituły Katedralnej w Tarnowie).

- [Spis poborowy województwa sandomierskiego 1508]. W: Źródta dziejowe. Wyd. A. P a wińs ki. T. 15. Warszawa 1886 s. $456-490$.

Rej. pob. 1536 - [Spis poborowy powiatu pilzneńskiego 1536]. Tamże s. 491556.

Rej. pob. 1581

- [Spis poborowy powiatu pilzneńskiego 1581]. W: Zródta dziejowe. Wyd. A. P a wi ńs ki. T. 14. Warszawa 1886 s. 241-269.

Rej. pob. 1629

Rej .pob. 1680

- Rejestr poborowy województwa krakowskiego z roku 1629. Oprac. W. Dom in i in. pod red. S. Inglota. Wrocław 1956.

- Rejestr poborowy województwa krakowskiego z roku 1680 wraz $\mathrm{z}$ aneksem miast według rejestru $\mathrm{z}$ roku 1655. Oprac. E. Trzyna i S. Zy g a pod red. S. In g l a ta. Wrocław 1959.

Słow. geogr.

- Słownik geograficzny Królestwa polskiego i krajów przyległych. Red. B. Chlebowski, F. Sulimierski i W. W a lew ski. T. 1-15. Warszawa 1880-1902.

Smoleń: Inwen$\operatorname{tarz}$

- Ks. W. Smoleń: Inwentarz kultu maryjnego w diecezji tarnowskiej. Arch. Bibliot. kośc. T. 1: 1959 z. 1 s. 81-133; †. 1: 1960 z. 2 s. $100-130$; t. $2: 1961$ z. $1 / 2$ s. $237-281$; t. $4: 1962$ s. $331-342$.

Starowolski 1655 - S. Starowolski: Vitae antistitum Cracoviensium. Cracoviae 1655.

Syr. 1621

- Reformationes generales ad clerum et populum dioecesis Cracoviensis pertinentes ab. ill. et rev. d. Martino Sz y s zk ows ki ep. Crac. in synodo dioecesana sancitae 1621. Cracoviae 1621 . 
Syn. 1711

WAP Kraków
WEP

Wiz. 1565

Wiz. ext. 1595

Wiz. int. 1595

W7iz. 1596

Wiz. 1597

Wiz. 1637

Wiz. 1664

Wíz. 1665

Wiz. 1669

Wiz. 1725

Wiz. 1748
- Synodus dioecesana ab ill. rev. d. Casimiro a Eubna Eubi eński ep. Crac. celebrata Cracoviae 1711. Cracoviae 1711.

- Wojewódzkie Archiwum Państwowe w Krakowie.

-. Wielka encyklopedia powszechna PWN. T. 1-5. Warszawa $1962-1965$.

- Liber visitationis ecclesiarum parochialium in civitate ac dioecesi Cracoviensi existentium auctoritate ill. ac rev. d. Philippi Padniewski ep. Crac. a. D. 1565 inchoatae. (Archiwum Kapituly Metropolitalnej w Krakowie. $\mathrm{Nr} 1$ ).

- Acta visitationis exterioris decanatuum Pilznensis, Ropcicensis, Biecensis, Mielcensis, Jaslensis et Zmigrodensis ad archidiaconatum Sandecensem pertinentium per Christophorum Kazimirski a. D. 1595 expeditae. (Archiwum Kapituły Metropolitalnej w Krakowie. $\mathrm{Nr}$ 2).

- Acta visitationis interioris decanatuum Pilznensis, Ropcicensis, Biecensis, Mielcensis, Jaslensis et Zmigrodensis in archidiaconatu Sandecensi iacentium per Christophorum $\mathrm{Kazi}$ mirski a. D. 1595 expeditae. (Archiwum Kapituly Metropolitalnej w Krakowie. $\mathrm{Nr} 4$ ).

- Acta visitationis exterioris decanatuum Tarnoviensis, Dobcicensis, Woynicensis, Opatovicensis, Lypnicensis et Wielicensis ad archidiaconatum Cracoviensem pertinentium per Christophorum Kazimirski a. 1596 expeditae. (Archiwum Kapituły Metropolitalnej w Krakowie. Nr 7).

- Visitatio ecclesiae collegiatae Tarnoviensis a. D. 1597 die $5 \mathrm{XI}$ expeditae. (Archiwum Kapituły Metropolitalnej w Krakowie. $\mathrm{Nr} 9$ s. $273-315)$.

- Visitatio tam exterior, quam interior ecclesiarum parochialium in decanatu Tarnoviensi existentium ex mandato r. d. Jacobi $\mathrm{Zadzik}$ ep. Crac. per v. d. Andream de Szczekarzewice Tarlo praepositum Tarnoviensem - - a. D. 1637 facta. (Archiwum Kapituły Metropolitalnej w Krakowie. $\mathrm{Nr} 43)$.

- Acta visitationis externae decanatus Tarnoviensis in a. D. 1664 per $\mathrm{r}$. d. Joannem M or a wi e cki scholasticum Tarnoviensem - - expeditae. (Archiwum Kapituly Metropolitalne w Krakowie. $\mathrm{Nr}$ 47).

- Visitationum ecclesiarum in decanatu Tarnoviensi - - [reformatio] 1665. (Archiwum Kapituly Metropolitalnej w Krakowie. $\mathrm{Nr} 48$ ).

- Visitatio externa - - decanatus Tarnoviensis per Nicolaum Oborski ep. Laodicensem, suffraganeum Crac. a. D. 1669. (Archiwum Kapituły Metropolitalnej w Krakowie. Nr 49).

- Ecclesia collegiata simul et parochialis Tarnoviensis visitata per ill. et rev. d. d. Constantinum $\mathrm{Sz}$ a $\mathrm{n}$ i a w ski ep. Crac. a. D. 1725. W: Róźne wizytacje 1725-1742 k. 61-74, 240-246'.

- Acta visitationis decanatuum Tarnoviensis et Voynicensis ex speciali delegatione cels. ill. et rev. d. d. Andreae Stanislai Kostka in Załuskie $\mathrm{Zazuski}$ - ep. Crac. per ill. et rev. Antonium de Beldow $\mathrm{B}$ e $ł \mathrm{~d}$ ow ski, primicerium et judicem delegatum Tarnoviensem - - praepositum in Przecław expeditae 1748 anno. (Archiwum Kurii Mretropolitalnej w Krakowie, Nr 47). 
Zbiór dokumen- - Zbiór dokumentów katedry i diecezji krakowskiej. Cz. I: tów katedry 1063-1415. Wyd. S. K u r ás. Lublin 1965. (Towarzystwo Naukowe Katolickiego Uniwersytetu Lubelskiego. Materiaty do Dziejów Koścıoła $w$ Polsce. T. 1).

W S T E P

\section{PREPOZYTURA, OFICJAEAT I DEKANAT TARNOWSKI}

\section{POWSTANIE, OBSZAR I GRANICE PREPOZYTURY TARNOWSKIEJ}

Charakterystycznym zjawiskiem przedrozbiorowej diecezji krakowskiej, na tle biskupstw polskich, był jej podział administracyjny, obok archidiakonatów, na prepozytury i dekanaty jako wyzsze jednostki organizacji wewnętrzno-terytorialnej. Najstarszy przekrój administracji diecezji krakowskiej z. r. 1326 wymienia 5 archidiakonatów (krakowski, lubelski, radomski, sandomierski i zawichojski) oraz dwie prepozytury (wiślicka i kielecką) ${ }^{1}$. Ostatni przekrój administracyjny całej diecezji z okresu przedrozbiorowego (1711) wymienia 6 archidiakonatów (krakowski, sandomierski, zawichojski, sądecki, lubelski, pilecki), 4 prepozytury (wiślicka, kielecka, tarnowska, pilecka) oraz dekanat kielecki ${ }^{2}$.

Prepozytury, jako jednostki terytorialnej organizacji wewnętrzno-diecezjalnej, występują tylko w biskupstwie krakowskim ${ }^{3}$. Jednakże okręgi prepozyturalne nie były czymś pośrednim między dekanatami a archidiakonatami, czy też ,podporządkowane archidiakonatowi”, jak to pisał Z. Kaczmarczyk ; stanowily one równorzędne archidiakonatom jednostki administracyjne. Nazwa prepozytury została zapożyczona od prepozyta kapituły kolegiackiej, który podobnie jak archidiakon posiadał $\mathrm{m}$. in. prawo wizytowania kościołów podległego mu okręgu. Poczatki tej instytucji w diecezji krakowskiej według jednych sięgają w. XII ${ }^{5}$, wedlug innych początków XIV stulecia ${ }^{6}$. Były one rezultatem usprawniania zarządu diecezją.

Geneza prepozytury tarnowskiej jest nieco inna. Na jej powstaniu nie zaważyły względy administracji kościelnej. Sam bowiem Tarnów, jak i dekanat tarnowski, jest zbyt blisko polozony od Krakowa, siedziby archidia-

1 MPV I s. 120 (archıd. krak.), 151 (prep. wiśl.), 158 (archid. zawich.), 163 (archıd. sand.), 168 (prep. klel.), 169 (arch1d. radom.), 171 (archid. lubel.). - Por. 壬 a ogórski: Studia s. $193-210$.

2 Syn. 1711 s. 7-16. - Dnia 1 XIf 1751 bp krak. A. S. Załuski utworzył nadto archidiakonat wojnıcki $\mathrm{z}$ wyłączonych $\mathrm{z}$ archıdiakonatu krakowskıego dekanatów wojnıckiego 1 lipmekıego, Zob. ks. B. K u m or. Organıacja archidiakonalna w Małopolsce Poludnowej. Prawo kanon. R. 2: $1959 \mathrm{nr}$ 1/2 s. 417. - J. Sz y m a ń k i: Powstane archidiakonatu wojnickiego i jego granice. Rocz. teol.-kanon. T. 5: 1958 [wyd. 1959] z. 4 s. 83-102.

3 T. Siln 1 ck 1: Organizacja archidiakonatu w Polsce. Lwów 1927 (Studia nad Historta Prawa Polskiego. T. 10. Z. 2) s. 115. - Ks. B. K u mor, Jw. s. 407. - E. W iśn i ow s i: Rozwój slecı parafialnej $w$ prepozyturze wiślickiej w średnıowıeczu. Warszawa 1965 s. 26.

4 Z. Ka czma rczy k: Monarchia Kazımierza Wielkiego. T. 2. Organizacja Kościola, sztuka i nauka. Poznań 1946 s. 73.

5 Ks. B. $\mathrm{K} \mathrm{u} \mathrm{m}$ or Organizacja archidiakonalna s. $407 \mathrm{n}$.

6 E. W 1 śn 10 W k k , jw. s. 31, 
konatu stołecznego. Główną przyczyną, która zadecydowała o powołaniu do życia prepozytury tarnowskiej, była centralistyczna polityka wielkiej własności ziemskiej, skupiającej w swych rękach duzy kompleks dóbr ziemskich wokół Tarnowa?. Kiedy w dniu 17 IV 1400 biskup krakowski Piotr Wysz utworzył, na prośbę Jana Tarnowskiego, wojewody sandomierskiego, kolegiatę przy kościele Narodzenia NMP w Tarnowie ${ }^{8}$, prepozyt jej otrzymał szerokie uprawnienia jurysdykcyjne kosztem archidiakona krakowskiego. Oprócz zarządu kolegiatą i jej duszpasterstwem biskup Wysz zlecił mu instalowanie prałatów, kanoników oraz ich wikariuszy, instytuowanie oraz usuwanie wikariuszy i altarzystów, kierowane służbą Bożą, wreszcie sądownictwo nad całym duchowieństwem kolegiaty $w$ sprawach cywilnych nie przekraczających 6 fl. pol. grzywny. Nadto biskup wyjął prepozyta spod wladzy archidiakona krakowskiego i uczynił go zależnym bezpośrednio od ordynariusza . Przywilej te nie tworzyły jeszcze prepozytury jako okręgu administracyjnego, ale dawały mccne fundamenty pod wyjęcie kolegiaty tarnowskiej spod władzy archidiakona krakowskiego.

Jeszcze ten sam Jan Tarnowski uzyskał od następnego ordynariusza krakowskiego, biskupa Wojciecha Jastrzębca, nowe przywileje dla kolegiaty tarnowskiej. W dniu $9 \mathrm{~V} 1416$ tenże ordynariusz zwiększył zakres kompetencji sądowniczej prepozyta tarnowskiego nad duchowieństwem kolegiaty w sprawach cywilnych do 10 grzywien, a nadto, za zgodą archidiakona krakowskiego, wyłączył 6 parafii dekanatu tarnowskiego: Skrzyszów, Szynwałd, Zalasowa, Poręba Radlna, Lisia Góra i Łękawica z jego archidiakonatu i poddał je prawu wizytacji prepozyta tarnowskiego ${ }^{10}$. W ten sposób powstał nowy okręg administracyjny w diecezji krakowskiej - prepozytura tarnowska. Biskup nie tworzył nowego archidiakonatu, ponieważ kapituła tarnowska nie posiadała jeszcze prałatury archidiakona. Kiedy w $1694 \mathrm{r}$. została ona utworzona, otrzymała przywileje czysto honorowe, a nie jurysdykcyjne. Wszystkie parafie nowego okregu prepozyturalnego wchodziły w skład wielkiej własności ziemskiej Tarnowskich; do nich też należał patronat i prawo prezenty nad wymienionymi kościołami. Pozostałe parafie dekanatu tarnowskiego, prawdopodobnie około 24, należały nadal do archidiakonatu krakowskiego ${ }^{11}$.

Dalszy rozwój terytorialny prepozytury przypada na wiek XVI i łączy się jak najbardziej $z$ tendencjami centralistycznymi własności ziemskiej Tarnowskich. W dniu 20 II 1481 Jan Amor Tarnowski zakupił od Stanisława Wlodkowicza z Jaryczowa i Anny, żony Jakuba z Felsztyna, wsie Wierzchosławice, Gosławice, Ostrów i Komorów wraz z prawem patronatu i prezenty do parafii Wierzchosławice ${ }^{12}$. Przez drugie małżeństwo - z Barbarą Zawiszanką $\mathrm{z}$ Rożnowa tenże Tarnowski pozyskał dla swej fortuny wsie: Wiewiórkę, Borowe, Jaźwiny, Mokre, Zassów, Nagoszyn, Korzeniów i Wolicę wraz $\mathrm{z}$ prawami patronackimi parafii Zassów ${ }^{13}$. W r. 1508 był on już

7 I.BD I s. $604 \mathrm{nn}$. — Rej. pob. 1536 s. $545 \mathrm{nn}$. - Rej. pob. 1531 s. 253 nn.

8 Por. Tarnów - parafia Narodzenia NMP.

- ASang. II nr 80 s. 94-97. - Por. F. H e rzig: Katedra, niegdyś kolegiata w Tarnowie. Tarnów 1900 s. 14.

10 ASang. Ir $\operatorname{nr} 106 \mathrm{~s} .126-127$.

11 KS. B. K u m or: Organizacja archidiakonalna $s .410$.

12 Asang. Ir nr $132-183$ s. $229-232 \mathrm{v}$.

13 Rej. pob. 1508 s. 466 . - Por. W D w or za c z k: Genealogia. Tablice. Warszawa 
$w$ posiadaniu parafii Zdziarzec, prawdopodobnie $\mathrm{z}$ patronatem ${ }^{14}$. To tez skupienie własności ziemskiej i praw patronackich wspomnianych trzech parafii (Wierzchosławice, Zassów, Zdziarzec) stało się przyczyna rozrostu terytorialnego prepozytury. Na prośbę Jana Tarnowskiego, kasztelana krakowskiego, biskup krakowski Piotr Gamrat, dokumentem z 12 V 1542, powięlkszył władzę sądownicza prepozyta tarnowskiego do 80 grzywien i spraw testamentowych do 30 grzywien $w$ całej prepozyturze, do której przyłączył trzy dalsze parafie: Wierzchosławice, Zassów i Zdziarzec ${ }^{15}$. Zarządzenie Gamrata potwierdził jego następca, biskup Samuel Maciejowski ${ }^{16}$.

Pod względem przynależności dekanalnej prepozytura tarnowska mieściła się w trzech dekanatach: 6 parafii - Lisia Góra, Łękawica, Poręba Radlna, Skrzyszów, Szynwałd i Zalasowa należało do dekanatu tarnowskiego, 1 parafia (Wierzchosławice) - do wojnickiego oraz dwie parafie (Zassów i Zdziarzec) — do pilzneńskiego ${ }^{17}$. Pod kọniec XVI stulecia kardynał Jerzy Radziwiłł włączył do prepozytury nowopowstała parafię w Jastrząbce Starej (własność ziemska $\mathrm{i}$ patronat Tarnowskich-Ostrogskich), wyjętą $\mathrm{z}$ okręgu parafialnego w Zassowie ${ }^{18}$. Wykreślone przez kard. Radziwiłła nowe granice dekanatu tarnowskiego objęły 17 parafii; $10 \mathrm{z}$ nich tworzyło okręg administracyjny prepozytury tarnowskiej, 7 zaś dalszych (Jurków, Góra Zbylitowska, Jodłówka, Pleśna, Piotrkowice, Tuchów i Ryglice) należało wprawdzie do dekanatu tarnowskiego, ale podlegały jurysdykcji archidiakona krakowskiego ${ }^{19}$.

W r. 1616 biskup krakowski Piotr Tylicki rozciągnął jurysdykcję prepozyta tarnowskiego na pozostałe 7 parafii tegoż dekanatu ${ }^{\mathbf{2 0}}$. Odtąd granice prepozytury pokrywały się z granicami dekanatu tarnowskiego. Tym razem rozrost terytorialny prepozytury był spowodowany względami administracji kościelnej, a nie, jak dotąd bywało, prośbami właścicieli Tarnowa.

Dalsze, nieznaczne poszerzenie granic prepozytury nastąpiło w drugiej połowie XVII w. Dnia 11 XII 1686 biskup krakowski Jan Małachowski przyłączył do niej nowowydzieloną z okręgów parafialnych w Dąbrowie Tarnowskiej (dek. opatowiecki, prep. wiślicka) i Lisiej Górze (prep. tarn.) parafię Luszowice ${ }^{21}$. Wreszcie w dniach 6-8 X 1711 biskup krakowski Kazimierz Eubieński włączył do prepozytury dwie dalsze parafie: Dąbrowę Tarnowska i Radgoszcz ${ }^{22}$. W r. 1759 biskup krakowski Ignacy Kajetan Soltyk potwier-

1959 tabl, 95. - E. Traj dos: Treści ideowe nagrobka Barbary z Roźnowa w katedrze tarnowskiej. Arch. Bibliot. kośc. T. 9; 1964 s. 47.

14 Rej. pob. 1508 s. 468. - Por. Wiz. 1596.

15 Asang. V nr 314 s. $333-343$

16 Tamże nr 341 s. 375 .

$17 \mathrm{Ks}$. B. K u m o r: Organizacja archidiakonalna s. 411.

18 Tamže s. 412. - Por. parafia Jastrząbka Stara.

10 Wiz. 1596 k. 17. Sequuntur parochiales ecclesiae in eodem decanatu [Tarnoviensi], quae non subiacent jurisdictioni seu officio praepositi Tarnoviensis. - Por. ks. B. K umor Rozwój sieci dekanalnej $w$ południowej części diecezji krakowskiej do r. 1772. Rocz-i teol.-kanon. T. 9: 1962 z. 1 s. $90 \mathrm{nn}$.

$20 \mathrm{Ks}, \mathrm{B} . \mathrm{K} \mathrm{u} \mathrm{mor}$ Organizacja archidiakonalna s. 412 . - F H e r zig, jw. s. 15.

21 AEp. Vol. 69 (1685-1689) k. 703-726, 796-798. - ADT: Fasc. Luszowice (Dokum. z. 11 XII 1686 - kopia): dictam novam ecclesiam parochialem Luszovicensem jurisdictioni praepositurae et officialatus perpetui Tarnoviensis subiecit. - F. Herzig (Katedra s. 15) podaje, ze stało sie to 31 III 1686.

22 Syn. 1711 s, 15, - Por, F, Herzig, jw. s. 15 , 
dził jeszcze raz prawa i granice prepozytury jako odrębnego okręgu administracyjnego ${ }^{\mathbf{2 3}}$.

W przeddzień pierwszego rozbioru Polski (1772) prepozytura tarnowska obejmowała 21 parafii $w$ granicach jednego dekanatu. Dla porównania podam, że w r. 1711 prepozytura wiślicka dzieliła się na 3 dekanaty (pacanowski, kijski, sokoliński) i posiadała lącznic 54 parafie; prepozytura kielecka 2 dekanaty (bodzentyński, kunowski) i 39 parafii; prepozytura pilecka 43 parafie w dekanatach lelowskim, jędrzejowskim, bytomskim i kijskim ${ }^{24}$.

Po pierwszym rozbiorze Polski organizacja terytorialna diecezji krakowskiej $z$ podziałem na archidiakonaty i prepozytury w części "galicyjskiej" biskupstwa przestała istnieć. Przygotowany w r. 1785 przez ks. Bochniewicza Spis wszystkich parafii majacych należeć do diecezji tarnowskiej nie zna podziału na archidiakonaty i prepozytury ${ }^{25}$, podobnie jak bulla erekcyjna tegoż biskupstwa wydana 13 III 1786 przez papieża Piusa VI ${ }^{26}$.

Uposażenie prepozyta stanowiło w większości beneficjum kościoła parafialnego Narodzenia NMP w Tarnowie przed wyniesieniem do godności kolegiaty. Nalezały doń: wieś Dąbrowka (Infułacka); folwark na przedmieściu Tarnowa wynoszący 1/2 łana frankońskiego; dziesięciny snopowe z 5-ciu łanów kmiecych w Dąbrówce, z 6-ciu łanów w Grabówce, z 2-ch łanów w Rzędzinie i Gumniskach; pastwiska w widłach rzecznych Dunajca i Białej; a nadto meszne $z$ Gumnisk, Krzyża, Klikowej $i$ inne pomniejsze dochody ${ }^{27}$. Prawo prezenty i patronatu do prepozytury przyslugiwało Tarnowskim oraz ich sukcesorom ${ }^{28}$.

\section{POWSTANIE, ROZWOJ I ZNIESIENIE OKRĘGOWEGO OFICJAEATU TARNOWSKIEGO}

Obok kolegiaty i siedziby prepozytury ad instar archidiaconatus Tarnów był również siedzibą oficjała okręgowego. Odnośnie początków oficjałatu tarnowskiego istnieją dwie różne hipotezy. Ks. J. Rzepa przyjmuje, że podwaliny prawne pod istnienie oficjałatu położył $12 \mathrm{~V} 1542$ biskup krakowski Piotr Gamrat, kiedy to zlecił prepozytowi tarnowskiemu $\mathrm{m}$. in. agendy sądownicze do 80 grzywien i testamentowe do 30 grzywien na obszarze całej prepozytury tarnowskiej ${ }^{1}$. Bp W. Wójcik, w oparciu o zachowane akta konsystorza tarnowskiego $\mathrm{z}$ lat $1535-1575$, umieszcza date powstania tego oficjałatu „między 1535 i, zdaje się, najwyżej 1500 r." ${ }^{2}$. Nie jest pozbawiona także pewnego prawdopodobieństwa hipoteza, że początki oficjałatu tarnow-

23 F. H e r zig, Jw. s. $15 \mathrm{n}$.

24 Syn. 1711 s. $12,16$.

25 Elenchus omnium parochiarum 1785.

$20 \mathrm{~K} \mathrm{u}$ m or: Dzieje s. $111-127 \mathrm{nr} 5$.

27 LBD I s. 606-609. - Por. F. H e rzig, fw. s. 16 n. - Ks. B. K u m or: Organizacja archidiakonalna s. 413.

28 ASang. II nr 80 s. 94-97.

1 ASang. V nr 314 s. 338 nn. - Por. ks. J. $\mathbf{R z}$ ep. Organizacja terytorialna sądownıctwa koścıelnego $w$ diecezji krakowskiej do pierwszego rozbioru Polski. Rocz- teol.-kanon. T. 4: 1957 z. 3 s. 100.

$2 \mathrm{Bp}$ W. Wófcik: Oficjalat okręgowy w Tarnowie w latach 1535-1575. Prawo kanon. R. 2: 1959 nr $1 / 2$ s. 386. 
skiego wiążą się z dokumentem biskupa krakowskiego Wojciecha Jastrzębca z $9 \mathrm{~V}$ 1416, mocą którego została powołana do życia prepozytura tarnowska ${ }^{3}$.

Obowiązki oficjała okręgowego pełnił z reguły prepozyt kapituły kolegiackiej ${ }^{4}$, chociaz $\mathrm{W}$ XVI w zdarzały się pewne wyjątki ${ }^{5}$. W zakres jego kompetencji wchodzily sprawy sporne, karne, notarialne $\mathrm{i}$ instytucje na beneficja kościelne ${ }^{6}$.

Terytorium oficjałatu pokrywało się najprawdopodobniej z granicami prepozytury tarnowskiej i poszerzało się wraz z jej wzrostem. Tak więc w r. 1542 oficjałat obejmował 10 parafii: Tarnów, Lisia Góra, Eękawica, Poręba Radlna, Skrzyszów, Szynwałd, Wierzchosławice, Zalasowa, Zassów i Zdziarzec. Pod koniec XVI w. przybyła parafia Jastrzabka ${ }^{7}$. W r. 1616 biskup krakowski Jakub Zadzik poddał jurysdykcji oficjała dalsze 7 parafii w dekanacie tarnowskim. W r. 1686 biskup Jan Małachowski włączył parafię Luszowice, a biskup Kazimierz Eubieński w r. 1711 - Dąbrowę Tarnowską i Radgoszcz ${ }^{8}$. Wszystkie te parafie $w$ kolejności lat byly poddawane przez biskupów krakowskich jurisdictioni seu officii praepositi Tarnoviensis.

Nieco innego zdania jest bp W. Wójcik. Przyjmuje on, że „teren oficjalatu tarnowskiego $\mathrm{w}$ latach 1535-1575 mieścił się w granicach prepozytury tej samej nazwy $\mathbf{i}$ obejmowal obszar tych parafii, które należały do niej w XVIII w." ". Wynikałoby $z$ tego, że już od XVI w. terytorium oficjałatu było ustalone i do r. 1772 nie podlegało żadnym zmianom. Źódła XVII-wieczne informują wprawdzie o istnieniu oficjałatu, ale nie podaja jego granic ${ }^{10}$.

Wydatnego powiększenia obszaru oficjałatu dokonał w r. 1773 biskup Ignacy Kajetan Sołtyk, w związku z reorganizacją "galicyjskiej" części diecezji krakowskiej. Do oficjałatu, który obejmował tylko dekanat tarnowski (21 parafii), wcielił on jeszcze 3 dekanaty: wojnicki, miechociński i rudnicki, oraz te części dekanatów witowskiego, opatowieckiego i urzędowskiego na prawym brzegu Wisły, które na skutek pierwszego rozbioru Polski zostały odcięte kordonem granicznym od Krakowa. W sumie $w$ oficjałacie znalazło się 54 parafii ${ }^{11}$. Dnia 1 II $1774 \mathrm{r}$. tenże biskup przekazał oficjałowi tarnowskiemu, ks. S. M. Swieykowskiemu, jurysdykcje nad wspomnianymi parafiami, a nadto nad dekanatem mieleckim (14 parafii). W obawie atoli przed nadmiernym wzrostem władzy oficjała tarnowskiego zastrzegł się biskup, że dekanaty te przyłącza do oficjałatu tarnowskiego w tym celu, ,aby dyspozycje dla terytoriów tychże okregów, czy to przez gubernium polityczne, czy też od naszego ordynariatu wydawane, latwiej byly rozsyłane po kościolach,

3 Por. pod prepozytura (p. 1).

4 Ks. J. $\mathrm{Rz}$ e p a, Jw. S. 101.

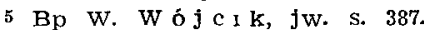

6 Tamze s. $388 \mathrm{n}$.

7 Por. wyzej, p. 2 (prepozytura).

8 Tamze.

9 Bp W Wój cik, jw. s. 386.

10 Syn. 1621 s. 18. - S t a r o w ols k 1: 1655 k. B.

11 AKMK. Prothocollum correspondentiae Cels. Prineipis Dni loci Ordinarii cum Excelso Gubernio Leopoliens1 annis 1773-1774. Vol. I s. 73. - Por. J. Rze pa: Konsystorz generalny w Tarnowie (1781-1785). Nasza Przesztość [T.] 7: 1958 s. 141. - Ks. W. Chotkowski: Historıa polityczna Kościoła w Galicji za rządów Marii Teresy. T. 2. Kraków 1909 S. 18 . 
ponieważ te właśnie dekanaty blizsze są Tarnowa" ${ }^{12}$. W rzeczywistości władza wspomnianego oficjała na przyłączonych terenach posiadała taki sam zakres, jak w oficjałacie tarnowskim ${ }^{13}$.

Ulegając presji rządu austriackiego, tenże biskup Sołtyk utworzył 27 II 1781 dla ,galicyjskiej" czéści diecezji krakowskiej oficjałat generalny w Tarnowie. Równocześnie zniósł on dotychczasowy tarnowski oficjałat okręgowy ${ }^{14}$. W dniu 13 III 1786 papież Pius VI, bullą In suprema beati Petri cathedra erygował diecezję tarnowską ${ }^{15}$, a 10 VI 1787 biskup tarnowski Florian Amand Janowski, na polecenie Gubernium Lwowskiego, zniósł po. zostałe oficjałaty okręgowe, istniejące w granicach nowo utworzonej diecezji ${ }^{16}$.

\section{DEKANAT TARNOWSKI}

Odnośnie do początków dekanatu tarnowskiego istnieją dwie różne hipotezy; pierwsza z nich, podpisanego, głosi, że początki jego, być może, sięgają końca XII w. Łącznie $z$ nim miały być utworzone dekanaty sądecki i jasielski ${ }^{1}$. Inna hipoteza, reprezentowana przez J. Szymańskiego, przyjmuje, że w XIII w. istnial dekanat wojnicki, a nie tarnowski; dekanat tarnowski miał powstać dopiero w latach $1470-1513^{2}$.

Wydaje się jednak, że przekazy źródłowe przemawiają za Tarnowem. Informujące zazwyczaj poprawnie wykazy dziesięciny papieskiej z lat 13251342 wymieniają aż 8 razy decanatus de Tarnow ${ }^{3}$, natomiast ani razu dekanatu wojnickiego; sam zaś Wojnicz 5 razy jest wyraźnie wymieniony w granicach dekanatu tarnowskiego ${ }^{4}$. Cecha charakterystyczną wykazów świętopietrza odnośnie organizacji dekanalnej jest częsta zmienność jej siedziby i nazwy, co zapewne nie odpowiada rzeczywistości. Wykazy świętopietrza $z$ lat 1346 - 1358, informujące bardzo często chaotycznie o organizacji dekanalnej, wymieniają sześciokrotnie dekanat tarnowski ${ }^{5}$, raz dekanat „tarnowski, który obecnie nazywa się wojnickim" (decanatus de Tarnov nunc est de Woynicz) ${ }^{6}$, dwukrotnie "dekanat tarnowski czyli górski" (decanatus de Tarnov vel de Góra) ${ }^{7}, 15$ razy ,dekanat wojnicki" ${ }^{8}$, który 5 razy poprawiono

\footnotetext{
12 Ks. W. Chotk owski, jw. s. 18. - Ks. J. Rzepa, jw. S. 142. - K u mor: Archidiakonat s. 293.

18 Ks. J. R z e p a, jw. S. 142.

$14 \mathrm{Kumor}$ : Dzieje s. 27. - Ks. J. Rzepa: Konsystorz s. 152, 161. - Ks. W. Chotkow s ki, jw. s. 14 .

15 Ku m or: Dzieje s. $36,111-127$.

16 Ks. J. Rz e pa, Jw. s. 169.

1 Ks. B. Kumor Początkı organızacji dekanalnej na ziemiach polskich. Rocz- \{ teol.kanon. T, 7, 1961 z. 2 s. 89-101.

2 J. Szy mań sk 1: Dekanat wojnickı w śwletle niektórych uwag o organizacji dekanalnej $\mathrm{w}$ diecezji krakowskıej w XIII-XVI w. Rocz-2 teol.-kanon. T. 8: 1961 2. 1 s. $75-35$.

3 MPV I s. $135 \mathrm{nn.,} 207 \mathrm{nn} ., 295,303$ n., 353, 355, 382, 394.

4 MPV I s. $136,207,303,382,394$.

5 MPV II s. 176, 183, 185, 188, 421, 424.

6 MPV II s. 337.

7 MPV II S. 428, 436.

8 MPV II S. 178, 180, 194, 203, 212, 222, 232, 241, 250, 258, 266, 274, 282, 289, 390.
} 
na „dekanat górski” i ośmiokrotnie ,dekanat górski" ๑. Rzecz godna uwagi, ze dekanat tarnowski występuje w początkowych i końcowych latach tych wykazów. Co więcej, podczas gdy wykazy świętopietrza z lat 1352, 1354 i 1355 nazywają omawiany dekanat "wojnickim" ${ }^{10}$, to wykazy dziesięciny papieskiej z tych samych lat dają mu nazwę „tarnowskiego", a w jednym wypadku „tarnowskiego lub górskiego" ${ }^{11}$.

Za wcześniejszą erekcją dekanatu tarnowskiego i wyłączeniem zeń dekanatu wojnickiego przemawia równicż enklawa terytorialna złożona $z$ trzech parafii (Gosprzydowa, Poręba Spytkowska i Tymowa), położonych na pograniczu dekanatu wojnickiego i lipnickiego. Parafie te jeszcze w XIV wieku zaliczane były do dekanatu tarnowskiego, a następnie także w latach 1513 , 1527, $1561 \mathrm{i} 1577^{12}$. Wykazy $\mathrm{z}$ lat $1513,1527,1529,1539,1561,1577^{13}$ zamieszczają parafie Tymowa i Gosprzydowa w dekanacie lipnickim i tak zapewne było wówczas. Ale zaliczenie, chociażby pomyłkowe, wspomnianych trzech parafii do tak odległego dekanatu tarnowskiego, a nie do najbliższego wojnickiego, świadczy o dawniejszej tradycji przynależności dekanalnej wspomnianych parafii, na której oparł się autor cytowanych wykazów ${ }^{14}$. Takiej „pomyłki" nie zrobiono w stosunku do dekanatu wojnickiego ${ }^{15}$. Co więcej, parafia Poręba Spytkowska we wszystkich przekazach umieszczana jest w dekanacie tarnowskim, a rzekoma jej przynależność w r. 1570 do dekanatu lipnickiego nie ma poparcia źródłowego ${ }^{16}$. Również zebrane elementy, które miały warunkować wybór Tarnowa, czy Wojnicza na siedzibę dekanatu ${ }^{17}$ nie przesądzają zagadnienia na niekorzyść Tarnowa. Wszak w XIII stuleciu kasztelański Biecz miał zapewne więcej podobnych elementów od cysterskiego Jasła, a jednakże siedziba dekanatu nie była w Bieczu tylko w Jaśle ${ }^{18}$. Zreszta również Tarnów posiadał ważne agendy administracyjne, kiedy tu do $1510 \mathrm{r}$. była siedziba powiatu, a nie w Wojniczu ${ }^{19}$. Wzmianki o istnieniu dekanatu wojnickiego w r. 1462 i $1470^{20}$ potwierdzają w pewnym sensie opinię podpisanego, że dekanat ten został erygowany przez kardynała Zbig-

8 MPV II S. 222, 232, 241, 250, 258, 297, 394, 411

10 MPV II S. 250, 266, 274.

11 MPV II S. 421, 424, 428, 436.

$12 \operatorname{LR} 1513$ k. 22', 23. LR 1527 k. $46^{\prime}, 48 .-$ LR 1561 k. 34 n. - LR 1577 k. 85.

$13 \operatorname{LR} 1513$ k. 17. - LR 1527 k. 37 n. - LR 1529 s. 30,150 . - LR 1539 k. 19. - LR 1561 k. 30. - LR 1577 k. $32 \mathrm{n}$.

14 Powoływanie sie przez J. Szymańskiego (Dekanat wojnicki s. 83) na akta wizytacyjne z r. 1570, jakoby wówczas obydwie parafie należały do dekanatu lipnicklego, niczego w tym wypadku nie potwierdza, ponıewaz ks. Glemma podzıal dekanalny diecezji krakowsklej zaczerpnął z wizytacji kardynała Radzlwilla (1595/96), a nle biskupa Padn1ewskıego. Por. ks. T, Gle m ma: Wizytacje diecezji krakowskiej z lat 1510-1570. Nasza Przesztość. [T.] 1: 1948 s. 70 przyp. 79, 85.

15 W r. 1542 wladza prepozyta tarnowskiego nie byla rozciagnięta na reszte parafii wchodzących $w$ skład dekanatu tarnowskiego, anı tez dekanat tarnowski nie pokrywał się z prepozyturą tarnowską, jak to pisze J. Szymańskı (Dekanat wojnickı s. 92). Do dekanatu tarnowskıego $w$ r. 1539 nalezalo 14 parafii, a tylko $7 \mathrm{z}$ nıch tworzyło prepozyture tarnowską, podczas gdy 3 dalsze: Wierzchosławıce, Zassów 1 Zdzıarzec, wchodzące od r. 1542 w skład prepozytury, należały do dekanatu wojnickiego (Wierzchosław1ce) 1 pilzneńskiego (Zassów, Zdziarzec). - Por. wyzej p. 1.

16 J. Sz y m ańs ki, Jw. s. 83, - Por. przyp. 14.

17 J. $\mathrm{sz} \mathrm{y} \mathrm{m}$ a ń ski, jw. s. 83 nn.

1s Por. ks. B. K u mor' Początki organizacji dekanalnej s. 93.

19 ReJ. pob. 1581 s. 258 przyp. 1.

20 J. Sz y m a n sk 1, Jw. s, 88 , 
niewa Oleśnickiego $(\dagger 1455)^{21}$. Trzeba atoli stwierdzić, ze ten sam teren $i$ te same parafie zaliczane są w latach 1346-1358 raz do dekanatu tarnowskiego, drugi do wojnickiego czy górskiego.

Poniższy wykaz ilustruje rozwój icrytorialny dekanatu tarnowskiego w latach 1325-1754.

\section{Dekanat tarnowski w latach $1325-1358$}

1325/27 - Tarnów, Wojnicz, Wierzchosławice, Jurków, Tuchów, Opatkowice, Tymowa, Gosprzydowa, Gno.jnik, Biesiadki, Uszew, Jasień, Dębno, Radlów, Góra (Zbyl.), Czchów, Gwoździec, Szczepanów, Poręba ${ }^{22}$ oraz Ples̉na i Iwikowa ${ }^{23}$.

1325/28 - Tarnów, Wojnicz, Wierzchosławice, Jurków, Opatkowice, Tymowa, Gosprzydowa, Gnojnik, Biesiadki, Uszew, Pleśna, Jasień, Dębno, Rađłów, Góra (Zbyl.), Czchów, Gwoździec, Szczepanów, Poręba ${ }^{\mathbf{2 4} .}$

1334 Jasień, Szczepanów ${ }^{25}$.

1336 - Tarnów, Wojnicz, Wierzchosławice, Jurków, Tuchów, Opatkowice, Tymowa, Gosprzyđowa, Gnojnik, Biesiadki, Uszew, Paleśnica, Jasień, Dębno, Radłów, Góra (Zbyl.), Czchów, Gwoździec, Poręba ${ }^{20}$.

1337 - Tarnów, Wojnicz, Jurków, Tuchów, Opatkowıce, Tymowa, Gosprzydowa, Biesiadki, Uszew, Jasień, Radłów, Góra, Czchów, Gwoździec, Poręba ${ }^{2 \overline{ }}$.

1339/40 - Tarnów (dek. tarn.) ${ }^{28}$.

1344 - Poręba (dek. tarn.) ${ }^{24}$.

1340 - Tarnów, Tuchów, Gosprzydowa, Biesiadki, Uszew, Pleśna, Dębno, Gwoździec, Szczepanów (dek. tarn.) ${ }^{30}$.

1346/47 - Tarnów, Wojnicz, Wierzchosławice, Jurków, Tuchów, Opatkowice, Tymowa, Gosprzydowa, Gnojrik, Biesiadki, Uszew, Pleśna, Jasień, Dębno, Radłów, Góra, Czchów, Gwoździec, Szczepanów, Poręba, Złota (dek. wojn.) ${ }^{31}$.

1348 - Dodano nadto: Gromnik i Paleśnica = Libertas Pelcze (dek. wojn.) ${ }^{32}$.

1349 - W stosunku do wykazu z r. 1348 dodano tylko Siemiechów (dek, wojn.) ${ }^{83}$.

1350 - Tarnów, Wierzchosławice, Jurków, Tuchów, Opatkowice, Tymowa, Gosprzyđowa, Gnojnik, Biesiadki, Uszew, Pleśna, Jasień, Dębno, Rađłów, Góra, Czchów, Gromnik, Gwoździec, Szczepanów, Poręba, Złota, Siemiechów, Szynwałd, Radina (dek. wojn.) ${ }^{34}$.

1351 - W stosunku do wykazu z r. 1350 wymieniono jeszcze Wojnicz i Ryglice (dek. wojn.) ${ }^{35}$.

1352 - W stosunku do r. 1351 wymieniono nadto: Nowy Tarnów, Skrzyszów, Eękawica; brak natomiast: Dębno, Szczepanów (dek. wojn.) ${ }^{36}$.

1358 - Tarnów, Wojnicz, Tuchów, Wierzchosławice, Jurków, Tarnów-Nowe Miasto, Opatkowice, Tymowa, Gosprzydowa, Gnojnik, Biesiadki, Uszew, Pleśna, Jasień, Radłów, Góra, Czchów, Gromnik, Gwoździec, Poręba Spytkowska, Złota, Siemiechów, Szynwald, Ryglice, Radlna, Skrzyszów, 毛官awica (dek. wojn.) ${ }^{37}$.

$1354-W$ stosunku do r. 1353 nie wymieniono: Siemiechów i Ryglice (dek. wojn.) ${ }^{38}$.

1355 - W stosunku do r. 1353 brak: Tymowa, Ryglice, Siemiechów, wymieniono zaś Szczepanów (dek. wojn.) ${ }^{39}$.

1356 - Tarnów, Wojnicz, Wierzchoslawice, Jurków, Tuchów, Tarnów miasto,

21 Ks. B. K u mor Rozwój siecı dekanalnej s. $85 \mathrm{nn}$.

22 MPV I s. 135-138, 207-210. 23 MPV I s. 209, 210, 24 MPV I s. 295, 305 n. 25 MPV I S. 353, 355. 26 MPV I s. 282 n. 27 MPV I s. 394. 28 MPV II s. 176 (dek. tarn.), 178, 180 (dek. wojn.), 183 (dek. tarn.). 29 MPV II s. 185.30 MPV II s. 188.31 MPV II s. $194,203$. 32 MPV II s. $212 \mathrm{n}$. 38 Tamze s. $222 \mathrm{n} .34$ Tamze s. 232.35 Tamze s. 241.36 Tamze s. 250. 37 Tamże s. $258 \mathrm{n}$. 38 Tamże s. 266 . 39 Tamże s. 274.40 Tamże s. 282. 41 Tamże 
Opatkowice, Gosprzydowa, Gnojnik, Biesiadki, Uszew, Pleśna, Jasień, Radłów, Góra, Czchów, Gromnik, Gwoździec, Poręba Spytkowska, Złota, Radlna, Skrzyszów, Eękawica, Szynwałd (dek. wojn.) ${ }^{40}$.

1357 - $W$ stosunku do r. 1356 wymieniono jeszcze Szczepanów (dek. wojn.) ${ }^{41}$.

1358 - W stosunku do r. 1356 brak parafii: Gosprzydowa, Góra, Gromnik, Poręba Spyt., wymieniono natomiast Ryglice (dek. gór.) ${ }^{42}$.

1350/51 - Tarnów, Wojnicz, Wierzchosławice, Jurków, Tuchów, Opatkowice, Tymowa, Gosprzydowa, Gromnik, Gnojnik, Biesiadki, Uszew, Pleśna, Jasień, Dębno, Loniowa, Radłów, Góra, Czchów, Gwoźdzıec, Szczepanów, Poręba, Iwkowa, Złoła, Skrzyszów, Szynwałd, Tarnów miasto, Eękawica (delr. $\operatorname{tarn}$.-wojn.) 43 .

1350/51 - Wojnicz (dek. wojn.) ${ }^{44}$.

1354/55 - W stosunku do r. 1350/51 brak parafii: Wojnicz, Tuchów, Iwkowa (dek. gór.) ${ }^{45}$.

1355 - W stosunku do r. 1350/51 brak parafii: Tymowa, Dębno, Góra, Szczepanów, Iwkowa (dek. gór.) ${ }^{46}$.

1352 - Wojnicz, Tuchów, Ryglice, Góra, Skrzyszów (dek. tarn.) ${ }^{4}$ i.

1355 - Ryglice, Góra (dek. tarn.) 48.

1354 - Dębno, Szczepanów, Skrzyszów, Tarnów-zamek (dek. tarn.-gór.) ${ }^{49}$.

1355 - Tymowa, Dębno, Szczepanów, Iwkowa, Skrzyszów, Tarnów-zamek (dek. tarn.-górn.) ${ }^{50}$.

Przekroju przynależności dekanalnej z lat 1373-1374 nie podajemy, ponieważ zamieszczony przez ks. T. Gromnickiego wykaz parafii dekanatu tarnowskiego odpowiada XVI stuleciu, a nie XIV ${ }^{51}$. Podobnie wykaz Długosza, jak to powiedziano na innym miejscu ${ }^{52}$, jest błędny i nie odpowiada ówczesnej rzeczywistości. Do dekanatu tarnowskiego czyli tuchowskiego zalicza on bowiem nastẹpujące parafie: Tarnów, Wojnicz, Stanchów (?), Cieklin (k. Jasła!), Paleśnica, Lanckorona (k. Wadowic!), Chronów, Lisia Góra, Poręba, Wierzchosławice, Zemboczyn (?), Skrzyszów, Iwkowa ${ }^{\overline{3} 3}$. Prawidłowy podział administracyjny diecezji krakowskiej podają dopiero przekroje od XVI stulecia -- księgi beneficjów retaksowanych.

\section{Dekanat tarnowski w latach 1513-1577}

1513 Tarnów, Tymowa, Gosprzydowa, Góra, Jurków, Lisia Góra, Skrzyszów, Eękawica, Zalasowa, Piotrkowice, Ryglice, Tuchów, Poręba, Poręba Radlna, Poręba Spytkowska ${ }^{54}$

1539 - Tarnów, Jurków, Góra, Lisia Góra, Skrzyszów, Szynwałd, Eękawica, Zalasowa, Piotrkowice, Ryglice, Tuchów, Poręba Spytk., Poręba Radlna ${ }^{55}$.

1561 - Tarnów, Góra, Jurków, Lisia Góra, Skrzyszów, Szynwałd, Zalasowa, Piotrkowice, Ryglice, „Poremba Palczonis”, Poręba Spytk., Poręba Radlna, Tymowa, Gosprzydowa ${ }^{56}$.

1577 - W stosunku do r. 1561 wymieniono jeszcze parafię Dąbrowa ${ }^{57}$.

Całkowicie pewne granice dekanalne podają wizytacje i synody diecezji krakowskiej z lat 1596-1754.

s. $289 \mathrm{n}$. 42 Tamze s. 297. 43 Tamze s. 337-339. 44 Tamze $\mathrm{s} . \quad 330.45$ Tamze s. $394 \mathrm{n}$. 46 Tamze s. 411.47 Tamze s. 421.48 Tamze $s .424 .40$ Tamze s. 428 . 50 Tamże s. 436.

51 Ks. Gromnickı (Swiętopietrze s. 366-369) wymienia parafie: 'Tarnów miasto, Tarnowiec, Tuchów, Zalasowa, Jurków, Ryglice, Poręba Radlna (Spytkowska!), Eękawica, Skrzyszów, Góra (Zbylit.), Szynwałd, Lısıa Góra, Radlna.

52 Ks. B. K u mor: Rozwój sieci dekanalnej s. 86.

53 LBD II S. $305-309$.

54 LR 1513 k. 22-23. - LR 1527 k. 45--48 (brak „Poręba RadIna”, ale jest „Poręba”).

55 LR 1539 k. $21^{\prime}-22 . \quad 56$ LR 1561 k. $33^{\prime}-34^{\prime}$. 57 LR 1577 k. $83-85$. 
Dekanat tarnowski w latach $1596-1754$

1596 - Tarnów, Lisia Góra, Zdziarzec, Jastrząbka, Zassów, Skrzyszów, Szynwałd. 1621 Zalasowa, Eękawica, Poręba Radlna.

1637 Wierzchosławice, Jurków.

1655 Góra, Jodłówka (Szczepanowska).

1644 Pleśna, Piotrkawice.

1655 Tuchów.

1669 Ry.glice 58.

1748 Dąbrowa, Radgaszcz, Luszowice ${ }^{50}$.

W takich granicach przetrwał dekanat do pierwszego rozbioru Polski, kiedy to obejmowal 21 parafii ${ }^{60}$. W dniu 16 IV 1784. Gubernium Lwowskie wydało rozporządzenie o nowym rozgraniczeniu dekanatów. Dnia $16 \mathrm{~V} 1784$ oficjal generalny i nominat na tworzące się biskupstwo tarnowskie, ks. Jan Duwall wprowadził $\mathrm{w}$ życie zarządzenia gubernialne ${ }^{61}$. Zniesiono wówczas m. in. dekanat tarnowski, a parafie należące doń przydzielono do dekanatu pilzneńskiego i radomyskiego. Ten też podział został przytoczony w bulli erekcyjnej dla diecezji tarnowskiej z 13 III $1786^{62}$.

\section{DEKANAT TARNOWSKI}

PARAFIA DABROWA TARNOWSKA (miasto)

Żródła przekrojowe: MPV I i II (1325-1358); Gromnicki: Swiętopietrze s. 372 n. (1328-1374), LBD I s. $11,15,405,406$; II s. $431-432,437,439$; Rej. pob. 1508 s. 487 ; LR 1513 k. 63'; LR 1527 k. 147; Rej. pob. 1536 s. 496-497; LR 1539

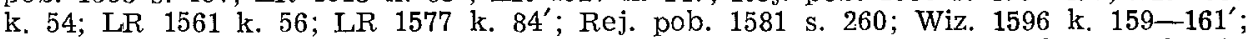
Wiz. 1610 s. $38-39$; Wiz. 1618 k. 109-110; Syn. 1621 s. 29; Starowolski 1655 k. C Wiz. 1664 s. $330^{\prime}-331^{\prime}$; Wiz. 1711 k. $145^{\prime}-147$; Syn. 1711 s. 15 ; Wiz. 1748 k. $104-123$.

Inne źr ódła: ADT: 1. Fasc. Dąbrowa Tarnowska (oryg. i kop. XVII-XX w.); 2. Specyfikacyja wszelkich realności i praw do kościoła parafialnego p. w. Wszystkich Swiętych obrządku łacińskiego w mieście Dąbrowy - - 1804 r. - Arch. Par. w Dąbrowie Tarnowskiej: 1. Liber documentorum ecclesiae ac beneficii parochialis Dąbroviensis. T. 1-3; 2. Dokumenty luźne (oryg. i kop. od XVII-XIX w.).

Ważniejsze opracowania: P. Gleń: Uposażenie parafii Dąbrowa Tarnowska od XIII do XIX wieku. Lublin 1964. Maszynopis W Zakładzie Historii KUL. - W. Demetry ki e w i z: Sprawozdanie z wycieczki w powiecie dąbrowskim, tarnowskim i bocheńskim. Teka konserwatorów Galicji Zachodniej. T. 1. Kraków 1900 s. 371 . - S m o le ń: Inwentarz. T. 1 z. 2 s. 100-101.

I A. Osada wzmiankowana pierwszy raz w r. $1325^{1}$. W r. 1698 wieś otrzymała prawa miejskie 2. Parafia, fundacji Ligęzów h. Półkozic, powstała pod

58 Wiz. 1596 k. $1-24^{\prime}$. - Sygn. 1621 s. 28. - Wiz, 1637 k. 371-377. - St a r o w o 1 s k 1

1655 k. $\mathrm{E}_{3}{ }^{\prime}$. - - Wiz. 1664 k. 470-556. - Wiz. 1665 s. 1-21. - Wiz. 1669 k. $1-28$.

59 Syn. 1711 s. 15. - Wiz. 1754 k. $1-135$.

$60 \mathrm{Ks}$. W. Chotkow k1, Jw. T. 1 s. 406 . Ks. B. K u mor, jw. s. 97.

61 Ks. J. R z e pa. Konsystorz generalny s. 169.

62 Por. Ku mor. Dzleje s. $116 \mathrm{n}$.

1 MPV I s. 157.

2 WEP II S. 835. 
koniec w. XIII ${ }^{3}$; pierwsza wzmianka z r. $1325^{4}$. W latach $1776-1779$ kościỏł został wyniesiony do godności prepozytury ${ }^{5}$.

Patronat: szlachecki ${ }^{6}$.

I B. Okręg parafialny ${ }^{7}$ za czasów Długosza obejmował: Dąbrowę, Brnik, Gruszów, Zdżary. W r. 1536 wspomniano nadto Radgoszcz, ale bez Gruszowa. W r. 1581 wymienione zostały: Dąbrowa, Nieczajna, Brnik, Wola Dąbrowska *, Żdżary, Szarwark, Radgoszcz i Ligęzów*. W r. 1596, oprócz wymienionych, występują: Gruszów i Luszowice. W r. 1618 dochodzi jeszcze Kaczówka. Przed r. 1686 przybyły nowe wsie: Smyków i Świerze ${ }^{8}$. 11 XII 1686 bp krak. Jan Machałowski, na prośbę Zygmunta z Tęczyna Tarły, starosty pilzneńskiego wyłączył wsie Luszowice, Smyków i Świerże i przydzielił do nowoutworzonej parafii Luszowice ${ }^{9}$. 11 II 1662 bp sufr. krak. Mikołaj Oborski wyłączył Radgoszcz jako „wikarię wieczystą" z własnym okręgiem parafialnym ${ }^{10}$. W r. 1748 wymieniono miasto Dąbrowę oraz wsie: Brnik, Bucze, Gruszów, Kaczówka, Żdżar, Nieczajna, Wola Dąbrowska *, Szarwark i „Kombów” *.

I C. W połowie XIV w. ludność parafii szacuje się na 450 osób ${ }^{11}$. W r. 1748 przystąpiło do komunii wielkanocnej około 3000 osób.

I D. Kościół parafialny, wspomniany przez Długosza, był w r. 1596 drewniany. W r. 1612, „po rozebraniu dawnego, małego kościoła", nową świątynię wybudował Mikołaj Ligęza z Bobrku, kasztelan żarnowiecki. 17 VIII 1614 konsekrował ją bp bakowski Walerian Lubieniecki ${ }^{12}$. W r. 1776 , „po rozpadnięciu się dawnego kościoła”, wybudowano ,nowy, z kostkowego, sosnowego drzewa, na fundamentach murowanych" staraniem parafian i hr. Potockiego ${ }^{13}$; konsekrował go w r. 1824 bp tarnowski G. T. Ziegler ${ }^{14}$.

Wezwanie: Wszyscy Swięci ${ }^{15}$.

I $\mathbf{E}_{1}$. Dąbrowa T. Kaplica drewniana, „obszerna", p. w. św. Jerzego M., została wybudowana na gruncie kościelnym przed r. 1614. 17 IX 1614 poświęcił ja bp bakowski W. Lubieniecki ${ }^{16}$. W r. 1748 potrzebowała naprawy, ale nabożeństwa w niej odprawiano. Wzmianka w r. 1711.

I $\mathrm{E}_{2}$. Dąbrowa T. Kaplica ,czyli oratorium", poświęcona, wybudowana przez Michała Lubomirskiego († 1714), podstolego koronnego ${ }^{17}$. W r. 1748 posiadała przywilej odprawiania mszy św.

I $\mathrm{E}_{3}$. Dąbrowa T. Kaplica murowana $\mathrm{w}$ pałacu Lubomirskich istniała W $1748 \mathrm{r}$.

3 P. G 1 e ń, jw. s. 13 n.

4 W dokumencie dla opactwa tynieckıego i mogilskıego z 18 IV 1329 wystepuje "Gosvynus plebanus de Dambroua". - Zob. Zbiór dokumentow katedry nr 33 s. 45-47.

5 ADT Specyfikacja 1804 S. 2 (praepositus ecclesiae Dạboviensis). - Por. Schematismus dioec. Tarnoviensis pro anno 1863 s. 34

6 LBD II s. 431. - Wiz. 1596-1748. - Por. P. G 1 e ń, jw. s. 13 nn.

7 Przekroje: LBD. - Rej. pob. 1536 i $1581 .$. - Wiz. 1596, 1618, 1748.

8 ADT: Fasc. Luszowice (kopıa dokumentu fundacyjnego par. Luszowice $z$ 11 XII 1686).

- Tamże.

10 ADT Fasc. Radgoszcz (kopia dokum, erekcyjnego).

11 王 a d og ór s k 1 : Studia s. 208.

12 Wiz. 1618 s. 109.

13 ADT. Specyfikacyja 1804 s. 1.

14 Schematismus dioec. Tarnov. 1863 s. 22

15 LBD. - Wiz. 1596-1748. - BAV: Elenchus omnium parochiarum $1785 \mathrm{nr} 33$. - AD'T: ST ecvfikacyja 1804 s. 1.

16) Wiz. 1748 s. 113

17 Tamże. 
I $\mathbf{E}_{4}$. Radgoszcz. Kościół filialny p. w. św. Kazimierza (zob. Radgoszcz).

I E. Szarwark. Kaplica czyli ,oratorium", murowana, „na folwarku", została wybudowana przez Antoniego Morskiego "dla własnych potrzeb" przed r. 1748 (,noviter erectum").

I F. Dąbrowa T. Szpital ,dla 18 ubogich" wybudował w r. 1607 Mikołaj Spytek Ligęza, właściciel miasta ${ }^{18} .27$ VIII 1619 zapisał on na rzecz szpitala 1500 fl. pol. ${ }^{19}$. 30 IV 1631 M. S. Ligęza, kasztelan sądecki pomnożył uposażenie szpitala ${ }^{20}$. W r. 1804 był ,szpital cały z cegły na glinie murowany" ${ }^{21}$. Wzmianki w latach 1618, 1711, 1748.

I $\mathrm{G}_{1}$. Dąbrowa T. Bractwo Ubogich erygował bp krak. P. Tomicki ( $\left.\uparrow 1537\right)$; zanikło ono przed r. $1596^{22}$.

I $G_{2}$. Dąbrowa T. Bractwo Różańca św., wraz z kapelanią, erygował 4 VI 1663 bp sufr. krak. Mikołaj Oborski ${ }^{23}$. Inne wzmianki w latach 1711, 1748, 1762, $1779^{24}$. (Por. I $\mathrm{M}_{2}$ ).

I H. Dąbrowa T. Szkoła parafialna istniała w r. 1596. W r. 1636 wizytator polecił ,wikarym i kierownikowi szkoły w niedziele i święta, przynajmniej przez godzinę, wykładać ludowi i chłopcom katechizm - - w języku rodzimym" ${ }^{25}$. W r. 1748 ,kierownik szkoły nie posiada własnego domu, tylko łącznie z organistą". Inne wzmianki w r. $1618^{26}$.

I $\mathrm{M}_{1}$. Dąbrowa T. Prebenda (altaria), nieznanego wezwania, została ufundowana przed r. 1513 („Altare novum”) ${ }^{27}$. Wzmianka w r. 1513.

I $\mathrm{M}_{2}$. Dąbrowa T. Prebendę przy ołtarzu M. B. Różańcowej, dla kapelana bractwa Rózańca św., ufundował Jerzy hr. Lubomirski, marszałek koronny dnia $9 \times 1662$, przeznaczając na ten cel 4000 fl. pol. $12 \times 1662$ fundację zatwierdził król Jan Kazimierz. Erekcji prebendy dokonał 4 VI 1663 bp sufr. krak. M. Oborski ${ }^{28}$. 23 XII 1762 i 10 XI 1779 nastąpiły dalsze zapisy na rzecz prebendy ${ }^{29}$. Inne wzmianki w latach $1711,1748$.

Patronat: szlachecki ${ }^{30}$.

I D. Dąbrowa T. Synagogę wybudowali żydzi w r. $1697^{31}$. Wzmianka W r. $1767^{32}$.

\section{PARAFIA GOR A Z BYLITOWSKA (wieś)}

Źródła przekrojowe: MPV I i II (1325-1358. J. Ptaśnik (MPV II s. 520) błędnie utożsamil ją z Lisią Górą k. Tarnowa); Gromnicki: Świętopietrze s. $366 \mathrm{n}$. (1328-1374, 1551-1559); LBD I s. $13,264,421,422,606,612$; II s. 114 ; LR 1513 k. 22';

18 Wiz. 1618.

10 Wiz. 1711-1748. - ADT: Fasc, Dąbrowa Tarn. (kop1a).

20 ADT: Fasc. Dąbrowa Tarn. (kopla).

21 Specyfikacja 1804 S. 2.

22 Wiz. 1596.

23 AKMK: AOffic. Vol. 141 s. $427-437$.

24 ADT Fasc. Dąbrowa Tarn. (kopıa dokum. z 1762, 1779).

25 K o t: Szkolnictwo, s. $308 \mathrm{n}$.

26 Por. $\mathrm{K} \circ \mathrm{t}$ : Szkolnictwo s. $308 \mathrm{n}$.

27 LR 1513 k. 64.

28 Zob. przyp. 23.

20 ADT: Fasc. Dąbrowa Tarn. (kople dokum.).

30 Zob. przyp. 23.

31 Wiz. 1748 s. 113: Synagoga Judeorum coepit esse - - ab an. 1697.

32 Archiw. Paraf. w Pliźnie: Prothocollum 2-dum dispositionum - - ab an. $1780 \mathrm{~s}$. 137 (regest dokum. z 1767 r.). 
LR 1527 k. $46^{\prime}$, LR 1529 s. 75; Rej. pob. 1536 s. 498-499; LR 1539 k. 22; LR 1561

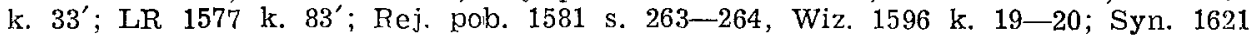
s. 18; Wiz. 1637 k. 377 ; Starowolski 1655 k. Es'; Wiz. 1664 s. 508-512, 546-549; Wiz. 1665 s. 17-18; Wiz. 1669 k. 25-27'; Syn. 1711 s. 15, Wiz. 1748 k. 96-103:

I nne źródła: ADT: 1. Fasc. Zbylitowska Góra (or. i kop. XVI-XX w.). 2. Fundationes praebendariorum Sacrat. Rosarii BMV et Ssmi Nominis Jesu in ecclesia parochiali Gorensi ( $\mathrm{z}$ XVII w.). - Archiw. Par. w Zbylitowskiej Górze: Prothocollum omnium dispositionum - - ab an. 1783-1826. - WAP Kraków: Castrensia Cracoviensia. Relationes 139a s. 2173-2181 (Inwentarz dóbr ziemskich w Zbylit. Górze z r. 1725).

I A. Parafia powstała prawdopodobnie w drugiej polowie XIII w. jako fundacja rycerska ${ }^{1}$; pierwsza wzmianka w r. $1325^{2}$.

Patronat: szlachecki ${ }^{3}$.

I B. Okręg parafialny za czasów Dlugosza obejmował miejscowości: Góre Zbylitowską, Sieciechowice, Swierczków, Komorów, Dąbrowę, Koszyce. W r. 1536 wymieniono nadto: Zgłobice, Koszyce Wielkie i Koszyce Małe, Wolę Swierczkowska * i Chyszów; Komorów natomiast zaliczono do parafii Wierzchosławice ${ }^{4}$. W r. 1581 występuje: Góra Zbylit., Koszyce Wielkie i Koszyce Małe, Chyszów, Swierczków, Zgłobice i Dąbrówka. Wiz. 1596 r. wymienia nadto Plewęcin i Kępę. W r. 1665 przekazy źródłowe wymieniaja jeszcze wieś "Ostrabowa" (późn. Wola Ostrębowska).

I C. Dla pierwszej polowy XIV w. ludność parafii szacuje się na 330 osób 5 . W r. $1664 \mathrm{w}$ poszczególnych wioskach parafialnych mieszkało łącznie 1019 osób; z czego w Zbylitowskiej Górze 132, Dąbrówce 96, Zgłobicach 167, Chyszowie 120, Sieciechowicach 44, Plewięcinie 30, Swierczkowie 131, Koszycach Małych 94, Koszycach Wielkich łącznie z folwarkiem 171 i „Ostrabowej” 34.

I D. Kościół parafialny w latach 1596-1748 był częściowo murowany (,in choro minori et sacristia), częściowo zaś drewniany (corpus ligneum), konsekrowany.

Wezwanie: Podwyzszenie św. Krzyża ${ }^{6}$.

I $\mathrm{E}_{1}$. Sieciechowice. Kaplica p. w. św. Anny, drewniana, konsekrowana, z. przywilejem mszy św., bez uposażenia, została wybudowana przed r. 1596. W r. 1665 „dach kaplicy potrzebował naprawy". Msze św. odprawiano trzy razy $w$ roku (wtorek po Wielkanocy i Zielonych Swiętach oraz 26 VII). W r. 1669 lkaplica ,była zaniedbana i zniszczona", dlatego wizytator kazał ja odnowić. W r. 1748 kaplica jest nazwana ,starodawną".

I $E_{2}$. Koszyce. Kaplica dworska „na folwarku”, z przywilejem mszy św., istniala w r. 1748 .

I F. Góra Zbylitowska. Szpital istniał w latach 1665-1669, ale ,potrzebował większej naprawy". W r. 1665 mieszkało w nim 11 ubogich, a w 1669 r. - 10. Inne wzmianki: 1748.

$1 \mathrm{Ku}$ mo r: Powstanie 1 rozwój sleci s. 523.

$2 \mathrm{~W}$ dokumencie z $13 \mathrm{~V}$ I276 wystepuje, ,Troianus rector ecclesiae de Gory" (KDPol. III nr 50 s. 113), ale nie wiadomo, czy przekaz odnosı się do zbylitowskiej Góry. Również w dokumencie z 2 I 1310 występuje ,Petrus plebanus de Gora" (MPV III nr 128 s. 105).

3 Wiz. 1596-1748.

4 Rej. pob. 1536 s. 552.

5 É a o gó r ski: Studia s. 201.

6 Wiz. 1596-1748. - Elenchus omnıum paroch1arum $1785 \mathrm{nr} 4$.

7 Wiz. 1596 k. $19^{\prime}$. 
I $G_{1}$. Góra Zbylit. Bractwo NMP (Literackie ?) i św. Marii Magdaleny istniało przed r. $1550^{7}$; w r. 1596 zaznaczono, ze „od 40 lat przestało istnieć”.

I $G_{2}$. Góra Zbylit. Bractwo Różańca św. przy kościele parafialnym erygowal, wraz z kapelania, 23 VI $1636^{8}$, bp krak. J. Zadzik, uroczystego wprowadzenia dokonali dominikanıe krakowscy $12 \mathrm{X} 1639$ r.". (Por. $\mathrm{MI}_{2}$ ). Inne wzmianki: $1665,1669,1748,1783^{10}$.

I G $_{3}$. Góra Zbylit. Trzeci Zakon św. Franciszka zaprowadzono przy kościele paraf. przed r. $1783^{11}$.

I H. Góra Zbylit. Szkoła parafialna w r. 1596 była „w lichym domu”, postawionym niegdyś dla wikarego. W r. 1665 kierownik szkoły „nie ma gorliwości około wprawiania młodziezy w nauki i śpiew”. W r. 1669 ,budynek szkolny potrzebuje naprawy". Inne wzmianki w r. $1637^{12}$.

I $\mathrm{M}_{1}$. Góra Zbylit. Prebenda p. w. św. Jana Chrzciciela została ufundowana 8 I 1539 i 2 VI 1540 przez Jakuba Rokosza, miejscowego dzierżawce, który na ten cel zapisał ,folwark i rolę" w Koszycach ${ }^{13} .14$ I 1667 Mikołaj Jordan z Zakliczyna, „dla powiększenia uposazenia prebendy", legował na jej cel 2000 fl. pol., co potwierdził 10 XII 1668 bp sufr. krak. Mikołaj Oborski ${ }^{14}$. Inne wzmianki: $1590^{1 \breve{s}}, 1596,1637,1665,1669,1748$.

I $\mathrm{M}_{2}$. Góra Zbylit. Prebendę przy ołtarzu M. B. Rózańcowej dla promotora bractwa Różańca św. ufundował ks. Aleksander Marcin Szaradzki, proboszcz wadowicki, przeznaczając (14 II 1636) na jej uposazenie $2000 \mathrm{fl}$. pol. ${ }^{16}$. Erekcji prebendy dokonał 23 VI 1636 bp krak. Jakub Zadzilk ${ }^{17}$. Inne wzmianki: 1665, $1669,1748,1783^{18}$. (Por. I $\mathrm{G}_{2}$ ).

Patronat: miejscowy proboszcz i Zbylitowscy ${ }^{19}$.

I $\mathrm{M}_{3}$. Góra Zbylit. Prebendę przy ołtarzu Najśw. Imienia Jezus ufundował 9 VII 1643 Aleksander Marcin Szaradzki, proboszcz wadowicki, przeznaczając na ten cel 2000 fl. pol., zabezpieczonych na 4 zagrodach we wsi Zgłobice. 26 II 1644 erygował ją bp krak. Piotr Gembicki ${ }^{20}$. Inne wzmianki: 1665, $1669,1748$.

Patronat: rada miasta Tarnowa ${ }^{21}$.

I $\mathrm{M}_{4}$. Góra Zbylit. Altarię p. w. bł. Jana Kantego zamierzał ufundować 5 IX 1754 kanon. krak. Mikołaj Lipski ${ }^{22}$. Nie wiadomo, czy fundacja została zrealizowana.

\footnotetext{
8 Fundationes prebendarıorum s. $1-3$

9 Tamże s. $13-14$.

10 Prothocollum 1783 pod $12 \times 1783$.

11 Tamze.

12 Por. Kot: Szlsolnictwo s. 318.
}

13 ADT. Fasc. Góra Zbylit. (insert dokum. z r. $1540 \mathrm{w}$ dokum. z 10 XII 1668). - AOffic. Vol. 145 s. 1208 (reg. dokum. z 2 VI 1540). --. Wiz. 1748 s. 98 (reg. dokum. z 8 I 1539 i 2 VI 1540). 14 AOffic. Vol. 145 (1667-1668) s. 1206-1216. - ADT: Fase. Góra Zbylit. (kopra).

is AKap'T: Officıalia Kazımerskl s. 47 (Institutio h. Felicis ad praebendam in Gora).

16 Zob. przyp. 13-14.

17 Fundationes praebendariorum s. 1-8.

18 Prothocollum 1783 (pod datą $z 12 \times 1783$ ).

19 Tamze. - Wiz. 1665 s. 548.

20 Fundationes praebendariorum s. 16--20. - AEp. Vol. 56 (2643-1644) k. 319-323. - ADT: Fasc. Góra zbylit. (kopie). - Fasc. Tarnów (Conscruptio erectionum, privilegıorum ac munimentorum Ecclesiae Collegiatae Tarnoviensis (z końca XVII w.) $n r$ 101 (reg.). - Wiz. 1665, 1748 (reg.).

21 Tamże.

22 W. Ketrzyński: Katalog rękopisów Biblioteki zakladu Narodowego im. Ossolińskich. T. 1. Lwów 1881 s. 110. 
V D. Góra Zbylit. Zbór ariański założył Fausto Sozzini († 1604) miał on istnieć przez pewien czas $\mathrm{w}$ XVII w. ${ }^{23}$.

\section{PARAFIA JASTRZĄBKA (wieś)}

Źródła przekrojowe: Rej. pob. 1581 s. 247 (par. Zassów); Wiz. 1596 k. $2^{\prime}-3^{\prime}$; Syn. 1621 s. 18; Wiz. 1637 k. 371'-372; Starowolski 1655 k. Es; Wiz. 1664 s. $475-477,526-527$; Wiz. 1665 s. 5-6; Wiz. 1669 k. $15^{\prime}-16^{\prime}$; Syn. 1711 s. 15; Wiz, 1748 k. $7-11$.

Inne źródła: ADT: 1. Fasc. Jastrząbka Stara (or. i kop. XVI-XX w.); 2. Status parochiae et ecclesiae parochialis Vetero-Jastrzębensis in visitatione decanali a. D. 1782 descriptus; 3. Summarium iurium et documentorum ecclesiae parochialis Vet. Jastrzębensis in visitatione decanali 1782 descriptus; 4. Status oeconomiae et proventuum ecclesiae parochialis Vet. Jastrzebensis a. D. 1782 descriptus; 5. Tabella ecclesiae parochialis in Jastrząbka tit. SS. Petri et Pauli (z XIX w.); APar. W Jastrząbce St.: Księga dokumentów parafii Jastrząbka Stara.

Ważniejsze opracowania: Smoleń: Inwentarz. T. 2 z. $1 / 2$ s. 248.

I A. Wieś została założona "na surowym korzeniu” ok. 1560 r. przez ks. Konstantego Ostrogskiego, wojew. kijowskiego ${ }^{1}$.

Placówka duszpasterska, wydzielona z parafii Zassów i uposażona ,lanem roli, wykarczowanej przez jednego z kmieci", powstała w r. $1563^{2}$. 28 VI 1581 parafię uposażył ks. Konstanty Ostrogski, wojew. kijowski ${ }^{3}$. $10 \mathrm{~V} 1595 \mathrm{r}$. ks. Elżbieta Ostrogska-Radziwiłłowa powiększyła uposażenie parafii ${ }^{4}$. Erekcji parafii dokonał 31 III 1599 kard. Jerzy Radziwiłł, bp krak. ${ }^{5}$.

Patronat: szlachecki ${ }^{6}$.

I B. Okręg parafialny obejmował w latach 1596-1782 tylko wieś Jastrząbkę Starą ${ }^{7}$.

I C. W r. 1637 do komunii wielkanocnej przystąpiło około 500 osób. W 1664 r. - 460, „wyjąwszy 23 inne osoby, które nie były do spowiedzi wielkanocnej". W r. 1748 ,tylko 200 osób”. W r. 1782 zamieszkiwało parafię 835 wiernych $^{8}$

I D. Kościól parafialny, drewniany, wybudowali w 1563 r. miejscowi chłopi ${ }^{9}$. Konserwacji kościola dokonał w 1587 r. abp lwow. J. D. Solikowski ${ }^{10}$. W latach 1596-1669 kościól był drewniany, konsekrowany. W r. 1748 wizytator zaznaczył, że ,jest starodawny i w nie najlepszym stanie". W r. 1789 kościół uległ pożarowi. Nową świątynię murowaną wybudował w latach

23 Schematismus dioec. Tarnov. 1863 s. 31 . - Schcmatismus dioec. Tarnov. 1875 s. 63. Słow. geogr. T. 14 s. 537.

1 Status parochiae 1782 s. 1.

2 Wiz. $1596 \mathrm{k}$. 3: Cum villa in nova radice locata fuit Jastrzębia, unus cmethonum laneum suum, suo opere elaboratum, pro ecclesia donavit; et vicini ejus suo sumptu ecclesiam aedificaverunt. kopia).

3 Wiz. 1596. - Status parochıe 1782 s. 1. - Księga dokumentów (đokum. z 28 vI 1531,

4 Summarium documentorum 1782 s. 1 (reg.).

5 AEp. Vol. 32 (1592-1596) k. 363-364.

6 Wiz. 1596-1748. - Status 1782 s. 1.

7 Przekroje: 1596, 1637, 1665, 1748, 1782 (Status 1782 S. 1).

8 Status parochrae 1782 s. 1.

$\theta$ Zob. przyp. 2.

10 Wiz. 1748. - Status parochiae 1782 s. 1. 
1791-1794 miejscowy właściciel Grzymała Siedlecki; konsekrował ją 25 VI 1825 bp tarnowski G. T. Ziegler ${ }^{11}$.

Wezwanie: św. Krzyż ${ }^{12}$. Nowy kościół, konsekrowany w r. 1825: św. Piotr i Pawel ap. ${ }^{\mathbf{3}}$.

I F. Jastrząbka St. Szpital został wybudowany przed r. 1665 przez chłopów i przez nich udotowany ,trzema stadiami roli". $28 \mathrm{~V} 1725$ legowano na rzecz szpitala $1000 \mathrm{fl}$. pol. ${ }^{14}$ a w 1746 r. $-2000^{15}$. W r. 1748 zaznaczono, że „szpïtal został zniszczony przez poprzedniego proboszcza”. W r. 1779 wybudowano nowy szpital ${ }^{16}$. W r. 1665 mieszkało $w$ nim 4 ubogich a w 1782 r. -5 .

I G. Jastrząbka St. Bractwo św. Aniołów Stróżów przy kościele paraf. zaprowadzono w r. $1695^{17} ; 18$ X 1718 zostało ono zatwierdzone przez oficjała tarnowskiego, ks. S. Jaroszyńskiego ${ }^{18}$. W r. 1727 bractwo otrzymało własnego kapelana ${ }^{1 "}$. Inne wzmianki: 1748, 1782. (Por. I M).

I H. Jastrząbka St. Szkoła parafialna w r. 1596 była ,w stanie niezbyt dobrym". W r. 1665 wizytator zauważył, że ,kierownik nie ma żadnej pilności około wprawiania młodzieży tak w nauki, jako też $w$ śpiewanie - budynek szkolny w stanie dobrym". Inne wzmianki: $1637^{20}$.

I M. Jastrząbka St. Prebendę dla promotora bractwa św. Aniolów Stróżów ufundowal w 1727 r. Kazimierz Siedlecki, podstoli przemyski, zapisując na ten cel $2000 \mathrm{fl}$. pol. ${ }^{21}$.

Patronat: szlachecki ${ }^{22}$.

PARAFIA JOD

Źródła przekrojowe: LBD I s. 13, 14, 15, 16; II s. 308; Rej. pob. 1508 s. 466; LR $1513 \mathrm{k} .21^{\prime}$; LR 1527 k. $44^{\prime}$; LR 1529 s. 68; Rej. pob. 1536 s. 545-546; LR 1539 k. 21; LR 1561 k. 98'; LR 1577 k. 87'; Rej. pob. 1581 s. 263; Wiz. 1596 k. 20-20'; Syn. 1621 s. 28; Wiz. 1637 k. 376'; Starowolski 1655 k. Es; Wiz. 1664 k. 505-508, 544-546; Wiz. 1665 s. 15-16; Wiz. 1669 k. 27'-28; Syn. 1711 s. 15; Wiz. 1748 k. $70-73$.

In ne źród la: ADT: Fasc. Szczepanowice (or. i kop. XVIII-XIX w.). APar. $w$ Szczepanowicach: Inventarium beneficii parochialis in Jodłówka a. D. 1785. - WAP Kraków: Castrensia Cracoviensia. Relationes 68 s. 614-623 (Inwentarz dóbr ziemskich Szczepanowice z r. 1642).

I A. Wieś wzmiankowana w r. $1398^{`}$. Parafia, fundacji szlacheckiej, powstała $\mathrm{w}$ drugiej połowie $\mathrm{w}$ XIV; pierwsza $\mathrm{w}$ zmianka $\mathrm{w}$ r. $1470^{2}$. W latach 1570-1596 parafia nie posiadała katolickiego duszpasterza. Około r. 1596

11 Tabella ecclesiae parochialis s. 1. - Księga dokumentów.

12 Wiz. 1596-1748. - Status parochiae 1782 s. 1. - Elenchus omnium parochiarum $1785 \mathrm{nr} 17$.

13 Zob. przyp. 11.

14 Status oeconomiae 1782 s. 2 (reg.).

15 Summarium jurium et documentorum a. D. 1782 s. 2.

16 Tamze.

17 Summarım jurium et documentorum a. D. 1782 s. 1

18 Status parochiae 1782 s. 1.

10 ADT: Fasc. Jastrząbka Stara (kopıa).

20 Por. K ot: Szkolnictwo s. 314.

21 Zob. przyp. 19.

22. Tamze.

1 Krzepe 1 a. Księga rozsiedlenia s. 434.

$2 \mathrm{~K}$ u mor: Powstanie 1 rozwóf siecl s. 528. 
Wojciech Chrząstowski wykupił prawa prezenty i patronatu z rąk różnowierczej rodziny i przedstawił na probostwo kapłana katolickiego ${ }^{3}$.

Patronat: szlachecki ${ }^{4}$.

I B. Okręg parafialny za czasów Długosza obejmował wsie ${ }^{5}$ : Jodłówka, Błonie, Lubcza, Dąbrówka, Szczepanowice, Lubinia (późn. Lubinka), Złotka*. W r. 1536 wymieniono nadto: Żelazówkę*, Chrząstów* i „Tssep"*. W r.1581 Błonie zaliczono do par. Wojnicz; brak natomiast: Szczepanowic, Złotki*, Zelazówki*, Chrząstowa* i „Tssep"*. W r. 1665 i 1748 podano: Szczepanowice, Zlotka*, Chrząstów*, Lubcza, Wola Błońska, Błonie, Lubinka, Izep*, Jodłówka i Wola Szczepanowska. W r. 1748 brak Chrząstowa.

I C. W r. 1664 do komunii wielkanocnej przystąpiło w poszczególnych wsiach paraf: Szczeparıwice - 157 osób, Złotka - 73, Lubcza - 35, Chrząstów i Dąbrówka - 68, Jodłówka i Wola Szczepanowska - 70, Wola Błońska i Błonie — 140, Lubinka - 64, Izep - 30, łącznie 638 wiernych. W 1748 r. - 700 osób.

I D. Kościół wzmiankowany przez Długosza, był w r. 1570 ,starodawny, drewniany, konsekrowany, rozpadający się ze wszystkich stron" ". Przed r. 1596 „kościół, zaniedbany przez heretyków, rozpadł się zupelnie" ?. Nowy, Iównież drewniany, wybudowal ok. 1596 r. Wojciech Chrząstowski. 3 VII 1620 konsekracji świątyni dokonał bp sufr. krak. Tomasz Oborski ${ }^{8}$. W latach 1637-1669 kościół był drewniany i konsekrowany. W r. 1748 został on gruntownie odnowiony przez miejscowego proboszcza.

Wezwanie: św Mikołaj b. i w. ${ }^{9}$.

I F. Jodłówka. W r. 1748 zaznaczono, ze parafia nigdy nie posiadała szpitala.

I H. Jodłówka. Szkoła parafialna w r. 1596 ,nie posiadała własnego budynku". W r. 1665 ,kierownik szkoly _- nie ma żadnej gorliwości około ćwiczenia młodzieży w naukach i śpiewie" ${ }^{10}$.

V A. Szczepanowice. Parafię luterańską założyli po 1570 r. Chrząstowscy, właściciele Szczepanowic. Przetrwała ona do r. $1808^{11}$.

Patronat: szlachecki ${ }^{\mathbf{1 2}}$.

V D. Zbór ufundowała rodzina Chrząstowskich prawdopodobnie przed r. $1596^{13}$. W r. 1713 drewniany gmach zboru spłonął $i$, mimo zakazu biskupa krak. (1719), został odbudowany. Jeszcze w $1808 \mathrm{r}$ odbył się w nim synod luteranów galicyjskich pod przewodnictwem pastora Dębickiego. Zbór upadł po r. $1809^{14}$.

3 Wiz. 1596. - Por. Ku m or Zanik i afiliacja s. 129.

4 Wiz. 1596-1748, - Inventarum 1785 s. 5.

5 Przekroje: LBD, 1536, 1581, 1665, 1748.

B AKapMK: Regestrum omnium ecclesiarum parochialium in dioec. Cracoviensi consistentium a. D. 1570 k. 194.

7 Wiz. 1596 k. 20.

8 Inventarium 1785 s. 5 .

9 Regestrum 1570 k. 194. - Wiz. 1596-1748. - Inwentarium 1785 s. 5.

10 Por. Kot: Szkolnictwo s. $317 \mathrm{n}$.

11 Merczyng: Zbory s. 179 n., 200 n. - Krasiński: Zarys s. 174 n.

12 Tamze.

13 Ok. r. 1596 Wojcıech Chrząstowski wybudował kościół katolicki w Jodłówce. - Por. K u m or Zanik i afiliacja s. 129.

14 Merczyng: Zbory s. 179 n.. 200 n. - Krasıfiski: Zarys s. 174. 
V F. Szczepanowice. Szpital zamierzał wybudować w 1665 r. Stanisław Chrząstowski ${ }^{15}$. Nie wiadomo, czy fundaça nastąpiła.

V H. Szczepanowice. Szkoła luterańska, „dla kształcenia chłopców szlacheckich i synów Szkotów", istniała w r. $1665^{10}$. Już w r. 1600 działał tu ks. Jan Petrycy, minister zboru, który wydał dzieło przeciwko arianom pt. Odpowiedź na skrypt Przestroga zwany ${ }^{17}$.

\section{PARAFIA JURKÓW (EFG TARNOWSKI)， wieś}

żród ła przekrojowe: IMPV I I II (1325-1358); Gromnicki: Swiętopietrze s. 366 n. $(1328-1374,1551-1558)$, LBD I s. $12,13,423,610 ;$ II s. $135-136,272$; III s. 197; ReJ. pob. 1508 s. 466; LR 1513 k. 22'; LR 1527 k. $46^{\prime}$; LR 1529 s. 444; Rej. pob. 1536 s. $497-498$; LR 1561 k. $33^{\prime}$; LR 1577 k. 84; Rej. pob. 1581 s. 250; Wiz. 1596 k. $17-18^{\prime}$; Syn. 1621 s. 28; Wiz. 1637 k. $374^{\prime}$; Starowolski 1655 k. E3, Wiz. 1644 k. 515-518, 552-553; Wiz. 1665 s. 20-21. Wiz. 1669 k. 12-13; Syn. 1711 Syn. 15; Wiz. 1748 k. 65-69.

Inne źródła: ADT: 1. Fasc. Jurków (or. i kop. XVI-XIX w.); 2. Status parochiae et ecclesiae paroch. Jurkoviensis in visitatione decanali a. D. 1784 descriptus; 3. Specyfikacja wszelkich realności i praw do szpitala we wsi Jurków - a. D. 1803.

Ważniejsze opra cowania: Smoleń: Inwentarz. T. 2, z. 1/2, s. 256 n.

I A. Parafia, fundacji rycerskiej, powstała w drugiej połowie w. XIII; pierwsza wzmianka z r. $1325^{1}$. 2 II 1599 Stefan i Jan Kozierowscy powiększyli uposażenie parafii, z tego powodu, że część dotychczasowych posiadłości ziemskich zabrały wody Dunajca ${ }^{2}$. Rzekomy dokument fundacyjny parafii $\mathrm{z} 3 \mathrm{~V}$ 1320, wystawiony przez Wiesława Lubomirskiego, jest falsyfikatem ${ }^{3}$.

Patronat: szlachecki ${ }^{4}$.

I B. Okręg parafialny ${ }^{\check{3}}$ za czasów Długosza obejmował: Jurków, Ilikowice, Rosławice*, Siedlec, Niedomice, Lęki*, Biała Wielka, Biała Mała i Krzeszowice*. Jeszcze w r. 1381 wymieniono wieś „Rudno, położoną w granicach parafii Jurków" ". W latach 1536-1581 podano: Bobrowniki (Wielkie i Małe), Dobczyce oraz Rudno; brak natomiast Krzeszowic* i jedna jest tylko Biała. W r. 1596 wymienione zostały: Jurków, Siedlec, Łęki*, Rosławice*, Ilkowice, Niedomice, Rudno, Bobrowniki, Biała, Wola w Łęgu*, Pogwizdów i Targowisko. W r. 1665, oprócz powyższych, wyliczono: Filipówkę*, Bobrowniki Wielkie i Bobrowniki Małe; brak zaś Woli w Eęgu* i Targowiska. Wiz. z 1748 nie wymienia Rosławic, Niedomic, Białej, Łęgu, Pogwizdowa i Targowiska; dodaje natomiast: Glów i Krochów*. Wreszcie w r. 1782 do parafii należały: Jurków, Biała, Bobrowniki, Siedlec, Łęki*, Partyń, Rudno, Łęg, Ilkowice, Sanoka, Grudeń (późn. Grudek) i Niedomice.

15 Wiz. 1665 s. 16.

16 Wiz. 1665 s. 16: schola pro exercendo Iuventute ejusdem sectae - - minister - Kałaj fovetque multos nobilium et scotorum pueros in litterarum studiis exercendos.

17 J. 王 u k a s e w i cz: Dzıeje koścıołów wyznanı helweckıego w dawnej Małej Polsce. Pozıań 1853 s. 343 .

1 K u m or: Powstanıe i rozwój sicc1 s. 521.

2 Aкарт Officialia Branickı s. 94-94'. - ADT: Fasc. Jurków (kopia z XVIII w.).

3 K u m or: Falsyfikaty s. 117.

4 LBD. - Wiz. 1596-1748. - Status 1784 s. 1.

5 Przekroje: LBD, 1536, 1581, 1596, 1665, 1748, 1782.

6 CDT I nr 106 s. 160 , - CDPol, III nr 163 s. 324-325, 
I C. Ludnòść parafii $w$ połowie XIV w. szacuje się na 525 osób? W r. 1664 z poszczególnych wsi parafialnych przystąpiło do komunii wielkanocnej łącznie 1465 wiernych, z czego z Jurkowa - 47, Eęgu - 273, Pogwizdowa - 173, Filipówki — 44, Niedomic - 104, IIkowic - 120, Rudna 119, Białej - 45, Łęki - 65, Siedlca - 117, Bobrownik Małych - 172 , Bobrownik Wielkich - 136. W r. 1748 komunię wielkanocną przyjęło 2000 osób. W r. 1784 w całej parafii mieszkało 2447 osób, z których do komunii wielkanocnej przystąpiło $1858^{\circ}$.

I D. Kościół parafialny, drewniany, wzmiankowany w latach 1325-1355, do czașów Długosza był kilkakrotnie zabierany przez wylew Dunajca; ,parafianie byli zmuszeni przenieść go na miejsce bardziej odległe od Dunajca" *. W r. 1596 kościół był drewniany i konsekrowany. W r. 1636 świątynię znów przeniesiono na inne miejsce, ,ze względu na wylew Dunajca" ${ }^{10}$. W r. 1637 była ona drewniana i niekonsekrowana. Wiz. z lat 1665/69 znowu informuje, że „świątynia została przeniesiona $\mathrm{z}$ dawnego miejsca nad brzegiem Dunajca na miejsce bardziej bezpieczne i bardziej odległe". 6 X 1669 konsekrował ją bp sufr. krakowski Mikołaj Oborski ${ }^{11}$. W r. 1784 zaznaczono, że „kościół był przenoszony $\mathrm{z}$ miejsca na miejsce; $\mathrm{z}$ powodu starości jest częściowo próchniejący i potrzebuje gruntownego remontu" ${ }^{12}$.

Wezwanie: św. Mikołaj b. i w. ${ }^{13}$.

I $E_{1}$. Jurków. Kaplica p.w. św. Aniołów Stróżów istniała w r. 1748. Późniejszych wzmianek brak.

I $E_{2}$. Rudno. Kaplica p. w. św. Sebastiana m., wybudowana została ze składek parafian w r. $1740^{14}$. Inna wzmianka: 1748.

I $E_{3}$. Bobrowniki. Kaplica ,na folwarku”, wystawiona przed 1748 r. przez miejscowych właścicieli.

I $F_{1}$. Jurków. Szpital, bez uposażenia, istnial w r. 1665. Przed r. 1705 sami ubodzy zbudowali ,dom szpitalny" ${ }^{15} .7 \mathrm{~V} 1705$ Antoni ze Szczepanowa Szczepanowski i Teresa z Czyżowa zapisali na rzecz szpitala $2000 \mathrm{fl}$. pol. ${ }^{10}$. W r. 1803 zaznaczono, że ,szpital, stojący pod kościołem, jest zbudowany z. drzewa rżniętego" "17. 10 XII 1738 ks. M. Wodzicki, oficjał gen. diec. krak., zatwierdził zapis 25 tys. fl. pol. na szpital i bractwo Trójcy św., uczyniony w tymże roku przez Helenẹ Morsztyn, wdowę po Antonim, wojew. inflanckim ${ }^{18}$. Inne wzmianki: $1748,1784^{19}$.

W r. 1665 mieszkało w szpitalu 7 ubogich; w r. 1705 fundacja przeznaczona była na utrzymanie 8 ubogich ${ }^{20}$.

7 E a d ogó r s ki: Studia s. 201.

8 Status 1784 s. 1.

- LBD II s. 235: ecclesiam etiam parochialem, ligneam aliquoties iam [Dunayecz] devoravit, et compulsı sunt parochiani eam transferre in locum a fluvio Dunayecz remotiorem.

10 Wiz. 1637 k. 374.

11 Wiz. 1669 k. 12.

12 Status 1784 s. 1.

13 Wiz. 1596-1748. - AKapT: Officialia Branicki s. 94. (dokum. z 2 II 1599). - Status

1784 s. 1. - Elenchus omnium parochiarum $1785 \mathrm{nr} 21$.

14 Wiz. 1748 k. 67'.

15 ADT. Fasc. Jurków (kopra dokum. z 7 V 1705).

16 Tamże.

17 Specyfikacyja 1803 s. 1.

18 AOffic. Vol. 175 (1738-1739) s. 490-518.

19 Status 1784 s. 12

20 Zob. przyp. 16. - Por. Wiz. 1748. 
I $\mathrm{F}_{2}$. Rudno. Szpital drewniany przy kaplicy św. Sebastiana istniał w r. $1784^{21}$.

I $G_{1}$. Jurków. Bractwo św. Aniołów Stróżów, wraz z kapelanią, zostało ufundowane przez ks. Wawrzynca Lechowicza, proboszcza w Wadowicach; w r. 1659 erygował je o. Augustyn Kordecki, prowincjal paulinów w Polsce i na Sląsku; w r. 1661 zatwierdził je bp krak. A. Trzebicki ${ }^{22}$. Inne wzmianki: $1712,1719,1748,1784^{23}$. (Por. IM).

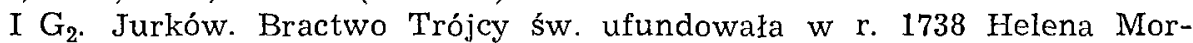
sztyn, wdowa po Antonim, wojew. inflanckim, erygował je 10 XII 1738 ks. M. Wodzicki, oficjał gen. diec. krak. ${ }^{24}$; 1 VI 1775 Dominik Potocki, starosta sokolnicki, zapisal na rzecz bractwa 3000 fl. pol. ${ }^{25}$. Inne wzmianki: $1784^{26}$.

I H. Jurków. Szkoła parafialna istniała w r. 1539 i $1586^{27}$. W r. 1596 „dom szkolny lichy"; wizytator poleca parafianom naprawić go. W r. 1637 zaznaczono, że ,szkoła została przeniesiona, wraz z kościołem, na bardziej odległe miejsce od Dunajca". W r. 1665 do szkoły uczęszczało 20 chłopców z parafii. W r. 1669 wizytator polecił proboszczowi, „by starał się zrujnowana szkołę według możliwości naprawić" ${ }^{28} .19$ X 1731 szkoła otrzymała niewielki legat pieniężny ${ }^{29}$. W r. 1748 była w stanie dobrym.

I M. Jurków. Prebendę dla promotora bractwa św. Aniołów Stróźów ufundował ok. 1659 r. ks. Wawrzyniec Lechowicz, zapisując na ten cel „pewną ilość ziemi”; erygował ją bp krak. A. Trzebicki w r. $1661{ }^{\mathbf{3 0}}$. 12 III 1712 Anna z Rajska, wdowa po K. Szembeku, legowała na rzecz prebendy 2000 fl. pol., zaś 29 XI 1713 Antoni Szczepanowski - 300 fl. pol. Fundację zatwierdził 10 XI 1719 bp sufr. i adm. diec. krak. Stanisław Hozjusz $^{31}$. Inne wzmianki: $1748,1784^{32}$.

Patronat: szlachecki ${ }^{33}$.

PARAFIA LISIA GÓRA (wieś)

Źródła przekrojowe: LBD I s. 12, 605, 609, 614; Rej. pob. 1508 s. 466; LR 1513 k. 22; LR 1527 k. 46'; LR 1529 s. 155; Rej. pob. 1536 s. 554-550; LR 1539 k. 22; Gromnicki: Swiętopietrze s. 368 n. (1551-1563); LR 1561 k. 33'; LR 1577 k. 84; Rej. pob. 1581 s. 261; Wiz. 1596 k. 1-2; Syn. 1621 s. 28; Wiz. 1637 k. 371-371'; Starowolski 1655 k. E $\mathbf{z}^{\prime}$; Wiz. 1664 k. 477-481, 554-556; Wiz. 1665 s. $21-23$; Wiz. 1669 k. $13-15$; Syn. 1711 s. 15 ; Wiz. 1748 k. $1-6$.

Inne źródła: ADT: 1. Fasc. Lisia Góra (or. i kop. XVI-XIX w.); 2. Consignatio documentorum necessariorum ad revindicanda avulsa beneficia Lisiogọrensi servientia ( $\mathrm{z}$ końca XVIII w.); 3. Inventarium ecclesiae parochialis Lisio-

21 Status 1784 S. 12.

22 Wiz, $1665,1748$.

23 ADT: Fasc. Jurków (dokum. z 1712 r., kopia). - AAdm. Vol. 24 (1719-1720) s. 368-376 (dokum. z 10 XI 1719). — Status 1784 s. 1.

24 AOffic. Vol. 175 (1738-1739) s. 490-518.

25 ADT Fasc. Jurków (kopia z XVIII w.). - Status 1784 s. 11.

28 Status 1784 s. 11.

27 AKapT: Officlalia Kazimierski s. 23.

28 Por. Kot: Szkolnictwo s. 319.

29 Wiz. 1748 (reg.).

30 Wiz. 1665 k. 553. - Wiz. 1748 k. 65'.

31 AAdm. Vol. 24 (1719-1720) s. 368-376. - ADT' Fasc. Jurków (kopia dokum. z 12 III 1712).

32 status 1784 s. 1.

33 Zob. przyp. 31. 
gorensis pro visitatione mense decembri a. D. 1739; 4. Status ecclesiae parochialis in Lisiagóra a. D. 1721; 5. Visitatio ecclesiae Lisiogorensis in a. D. 1749; 6. Opis sytuacyi kościoła Lisıogróskiego dn. 18 III 1760 r.; 7. Tabella ecclesiae paroch. S. Adalberti - comparata a. D. 1814.

Ważniejsze opracowania: Smoleń: Inwentarz. T. 4. s. 339 n.

I A. Parafia fundacji Lelewitów-Tarnowskich powstała w drugiej polowie w. XIV; pierwsza wzmianka w r. $1416^{1}$. 9 II 1638 bp krak. Jakub Zadzik powiększył uposażenie parafii przez przydzielenie jej dziesięcin $z$ nowolokowanych wsi ${ }^{2}$. Rzekomy dokument fundacyjny parafii z 8 IX 1362, wystawiony przez S. Miszkowskiego, jest falsyfikatem ${ }^{3}$.

Patronat: szlachecki ${ }^{4}$

I B. Okręg parafialny za czasów Długosza ${ }^{5}$ obejmował $\mathrm{m}$. in. wsie: Lisia Góra i Eukowa. W r. 1536 wymieniono nadto: Śmigno, Wola*, Pawezów, Krzyz, Żukowice, Luszowice, Dąbrowa (Dąbrówka), Bogumiłowice i Biadoliny. Trzy ostatnie wioski zostaly błędnie zaliczone do par. Lisia Góra. W r. 1581 w granicach parafii były: Lisia Góra, Łrukowa, Zukowice, Luszowice, Pawęzów, Wola Lisiogórska*, Smigno, Kobierzyn. W r. 1596 wymieniono jeszcze: Krzyż, Wymysłów, Wola Breńska i Brzeziny (późn. Brzozówka). W r. 1638 bp krak. J. Zadzik przyłaczył do parafii nowo założone wsie: Lipiny, Zaczarnie, Piaski i Breń ${ }^{6}$. W r. $1665 \mathrm{w}$ skład parafii wchodziło 13 wsi: Lisia Góra, Zukowice, Śmigno, Pawęzów, Lipiny, Zaczarnie, Kobierzyn, Łukowa, Wymysł, Wychylówka, Breń, Piaski i Krzyż. W r. 1683 Lipiny zostały włączone do nowoutworzonej parafii Luszowice (Zob. Luszowice I B.). W latach 1748/49 wymieniono nadto: Okręglik, Jodłówka „per medium”, Marszówka, Dębrza, Żukowice Stare i Nowe, Laski oraz Jastrząbka Nowa; brak natomiast Wychylówki. Podrobiony ok. 1770 r. dokument fundacyjny parafii wymienia w jej granicach wsie: Lisia Góra, Pawęzów, Zaczarnie, Śmigno, Jastrząbka (Nowa), Łukowa, Kobierzyn, Zukowice, Laski, Breń, Nowa Wies, Granice, Kaczówka, Jodłówka, Dębrza Partyńska i Wymysł?

I C. W r. 1637 przystąpiło do komunii wielkanocnej około 3000 osób. W r. 1664 z całej parafii przyjẹło komunię wielkanocną 2543 wiernych, przy czym ze wsi Lisia Góra - 638, Żukowice - 462, Śmigno - 186, Pawęzów - 164, Lipiny — 249, Zaczarnie - 290, Kobierzyn - 130, Eukowa - 186, Wymysł - 56, Wychylówka - 23, Breń - 87, Piaski - 38 i Krzyż — 34. W latach $1748 / 1749$ - 3400 osób z calej parafii. W r. 1814 w parafii mieszkały 5652 osoby nadające się do przyjęcia komunii św. i 1410 „, niezdatnych"; łącznie $7062^{8}$.

I D. Kościół parafialny, wzmiankowany przez Długosza, był w latach 1596-1669 drewniany i konsekrowany W r. 1712 został strawiony przez po-

1 Kumor (Powstanie i rozwój sieci s. 524) podaje, ze stalo się to przed r. 1350. - Por. T. La den berger: Zaludnıenıe Polskı na początku panowanıa Kazimierza Wielkiego. Lwów 1930 s. 67. - Wzmianka z 1 I 1381 (CDT I nr 106 s. 160) odnosi się do Góry Zbylitowskiej.

2 ADT: Fasc. Lisia Góra (kopia z XVIII. w.).

3 K u mor: Falsyfikaty s. 118.

4 Wiz. 1596-1749.

5 LBD, 1536, 1581, 1596, 1665, 1748, 1749.

6 ADT: Fase. Lisia Góra (kopia).

7 ADT: Fasc. Lisia Góra (kopıa z XVIII w.).

8 Tabella 1814 s. 1 . 
zar ${ }^{9}$. W latach 1716-1728, staraniem ks. Macieja Schabowicza i jego następcy ks. Jana Fabiankowskiego, został wybudowany kościół nowy $\mathrm{z}$ kamienia i cegły: 17 X 1734 konsekrował go bp sufr. krak. Michał Kunicki ${ }^{10}$. I IV 1747 kościół spalił się ponownie. Odbudował go w roku następnym ks. Józef Przytycki, kan. tarnowski i proboszcz w Lisiej Górze ${ }^{11}$.

Wezwanie: św. Wojciech b. i m. ${ }^{12}$. Nową świątynię wybudowaną $w$ latach 1716-1728, konsekrował bp M. Kunicki p. w. św. Wojciecha i Stanisława b. $\mathrm{i} \mathrm{m}^{13}$.

I F. Lisia Góra. Szpital w r. 1665 ,potrzebował w całości gruntownego remontu". Ok. 1721 r. nowy szpital wybudowal ks. Schabowicz ${ }^{14}$. W r. 1665 mieszkało w nim 7 ubogich. Innych wzmianek brak.

I G $G_{1}$. Lisia Góra. Bractwo Rózańca św. zostało zaprowadzone przed r. 1665 . $21 \mathrm{X}$ i 18 XII 1710 bractwo otrzymało uposazonego promotora ${ }^{15}$. Inne wzmianki: 1669, 1748, 1749, 1814 ${ }^{16}$. (Por. I M).

I G $\mathrm{G}_{2}$. Lisia Góra. Bractwo św. Nepomucena erygowal 8 III 1770 papiez Klemens XIV; 11 II 1771 zatwierdził je i obdarzył licznymi odpustami bp krak. Ignacy Kajetan Sołtyk ${ }^{17}$. 20 V 1776 tenże ordynariusz wznowił erekcję bractwa i potwierdził legaty na rzecz jego promotora ${ }^{18}$.

I H. Lisia Góra. Szkoła parafialna istniala w r. 1513 i $1586^{19}$. W r. 1596 „była w stanie lichym"; juizytator nakazał parafianom naprawić szkołę. Inne wzmianki: $1665^{20}$. Około 1770 r. szkołę i jej uposażenie opisuje rzekomy dokument fundacyjny parafii ${ }^{21}$.

I M. Lisia Góra. Prebenda dla promotora bractwa Różańca św. została ufundowana $21 \mathrm{X}$ i $18 \mathrm{XII}$ 1710. Promotorem miał być każdorazowy miejscowy proboszcz ${ }^{22}$. (Por. $I G_{1}$ ).

Patronat: szlachecki ${ }^{28}$.

\section{PARAFIA L USZOW ICE (wieś)}

Źrodła przekrojowe: Rej. pob. 1536 s. 555; Rej. pob. 1581 s. 261 (par. Lisia Góra); Syn. 1711 s. 15; Wiz. 1748 k. 129-135.

Inne źródła: ADT: 1. Fasc. Luszowice (or. i kop. XVII-XIX w.); 2. Inwentarz - - plebanii w Luszowicach - - mense augusto zrobiony - - $1814 \mathrm{i}$. $\mathrm{W}$ : Collectio inventariorum decanatus Radomyslensis (bez paginacji); 3 . Index chronologicus documentorum ecclesiae Luszovicensis ( $z$ konca XVIII w.).

I A. Wieś wymieniona po raz pierwszy w r. 1536. Placówka duszpasterska istniała około r. 1660; 10 III 1660 bp krak. Andrzej Trzebicki rozpo-

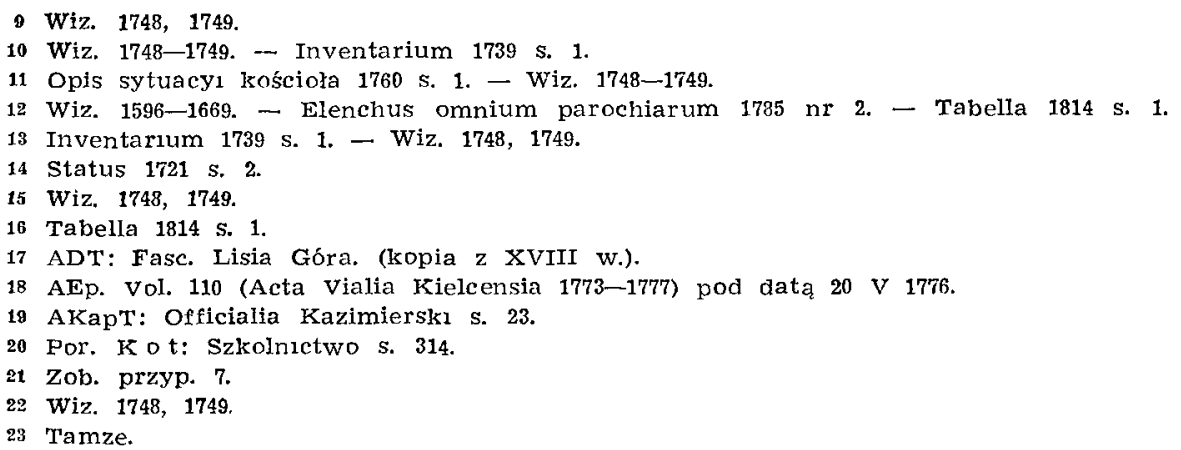


czą 1 proces $w$ sprawie utworzenia samodzielnej parafii ${ }^{1}$. 20 III 1683 Zygmunt Tarło, starosta pilzneński, uposażyl parafię, którą erygował 11 XII 1686 bp krak. Jan Małachowski ${ }^{2}$.

Patronat: szlachecki ${ }^{3}$.

I B. Okręg parafialny został wydzielony z parafii Dąbrowa i Lisia Góra; w r. 1686 obejmował on: Luszowice, Świerże, Lipiny i Smyków ${ }^{4}$. W r. 1748 wymienione zostały nadto: Stara Wieśs, Kąty*, Dębowiec i Jeziorki.

I C. W r. 1748 przystąpiło do komunii wielkanocnej 988 osób.

I D. Kościól parafialny, z drewnianym prezbiterium, wybudował w roku 1686 Zygmunt Tarło; budowy, z cegły i kamienia, dokończył przèd r. 1729 jego syn, Franciszek Tarło, kasztelan lubelski i starosta pilzneński. 26 X 1687 konsekracji kościoła dokonał bp krak. Jan Małachowski ${ }^{5}$.

Wezwanie: Św. Józef Obl. NMP, św. Zygmunt m. i św. Kazimierz w. św. Józef Obl. NMP (1785) ${ }^{7}$.

I F. Luszowice. Szpital przy kościele paraf. istniał w r. 1748; mieszkało W nim 6 ubogich.

I G. Luszowice. Bractwo św. Józefa istniało $w$ r. $1714^{8}$. 3 VII 1715 bp sufr. krak. M. Szembek erygowal kapelanię dla promotora bractwa ? Inne wzmianki: 1748. (Por. I M).

I M. Luszowice. Prebendę dla promotora bracłwa św. Józefa ufundował Franciszek Tarło, starosta pilzneński, legując na ten cel $2000 \mathrm{fl}$. pol. (14 XII 1714); kapelanię erygował 3 VII 1715 bp sufr. krak. Michał Szembek ${ }^{10}$. Inne wzmianki: 1748.

Patronat: szlachecki ${ }^{11}$.

\section{PARAFIA $€$ F}

Źrodła przekrojowe: MPV II (1350-1358); Gromnicki: Swiętopietrze s. 366 n. (1351-1374, 1551-1556, 1560-1562); LBD I s. 605, 609; II s. 280; Rej. pob. 1508 s. 466 ; LR 1513 k. 22'; LR 1527 k. 47'; LR 1529 s. 181 ; Rej. pob. 1536 s. 551; LR 1539 k. 22; LR 1561 k. 34; LR 1577 k. 84; Rej. pob. 1581 s. 264; Wiz. 1596 k. 12-14; Syn. 1621 s. 28; Wiz. 1637 k. $375^{\prime}-376$; Starowolski 1655 k. Es'; Wiz. 1664 k. 483-486, 529-531; Wiz. 1665 s. 7-8; Wiz. 1669 k. 21'-22; Syn. 1711 s. 15; Wiz. 1748 k. $45-49$.

In ne źródła: ADT: 1. Specyfikacja wszelkich realności i praw do kościola pt. Św. Mikołaja biskupa - - we wsi Eękawicy $1814 ; 2$. Conscriptio erectionum, privilegiorum ac munimentorum Ecclesiae Collegiatae Tarnoviensis ( $z$ końca XVIII w.); 3. Fasc. Eękawica (or. i kopie od XVII-XIX w.); 4. Tabella beneficii parochialis Eękawicensis in decanatu Pilsnensi a. D. 1784.

1 AEp. Vol. $60 \quad(1660-1661)$ K. $139-143$.

2 AEp. Vol. 69 (1685-1688) s. 708-726, 796-798, 1057-1058. - ADT: Fasc. Luszowice (kopie dokum. fund. $\mathrm{i}$ erekcyjnego $\mathrm{z}$ XVIII w.). - Inwentarz 1814 (kopie $\mathrm{z}$ XVIII w.). - Conscriptio $\mathrm{nr} 114$ (reg.).

3 Tamże.

4 Tamze.

5 Wiz. 1748. - ADT. Fasc, Luszowice (dokum, z 11 XII 1686).

6 Tamze.

7 Elenchus omnium parochiarum $\mathrm{nr} 34$.

8 AOffic. Vol. 166 (1714-1719) s. $75 \mathrm{n}$.

- ADT: Fasc. Luszowice (dokum. z 3 VI 1715 - or. pap.). - AOffic. Vol. 166 (1714-1719) 5. $356-374$.

10 Zob. przyp. 9.

11 Tamże. 
Ważniejsze opracowania: F. Herzig Katedra s. 53 n. - Kumor: Zanik i afiliacja s. $110 \mathrm{n}$.

I A. 11 V 1344 Kazimierz Wielki, na prośbę Spycimira, kasztelana krak., zezwolił $\mathrm{m}$. in. na przeniesienie wsi na prawo niemieckie ${ }^{1}$. 17 II 1399 Wojciech, sędzia i Mikołaj, podsędek ziemi sandomierskiej, potwierdzili sprzedaż wsi, dokonaną przez Pełkę na rzecz Jana Tarnowskiego, wojew. sandomierskiego, za 50 grzywien ?.

Parafia, fundacji Leliwitów, powstała w latach 1344-1350; pierwsza wzmianka z r. $1350^{3}$. W r. 1559 , za zgodą Jana Tarnowskiego, kasztelana krak., beneficjum parafialne zostało inkorporowane do prebendy kaznom dziejskiej przy kolegiacie w Tarnowie, a przy kościele w Łękawicy utworzona została „wikaria wieczysta" 4. Prawdopodobnie w 1701 r. kościół otrzymał powtórnie prawa parafialne ${ }^{5}$. Rzekomy dokument fundacyjny parafii z 1314 r., wystawiony przez Dersława Firleja, rycerza maltańskiego, jest falsyfikatem ${ }^{\circ}$.

Patronat: szlachecki (do 1559), kapituly kolegiackiej w Tarnowie (po 1559) ?

I B. Okręg parafialny w latach 1536-1748 obejmował dwie wsie: Łękawica i Trzemeśna ${ }^{8}$.

I C. Ludność parafii dla połowy XIV w. szacuje się na 570 osób 9 . W r. 1664 przystąpilo do komunii wielkanocnej 562 osoby, zaś w 1748 około 400.

I D. Kościól parafialny, wzmiankowany w latach $1350-1358$, by w r. 1596 murowany i konsekrowany. W r. 1637 zaznaczono, że jest „zbudowany z kamienia".

Wezwanie: św. Mikołaj b. i w. ${ }^{10}$.

I F. Eękawica. Szpital, stojący przy kościele paraf., był w r. 1596 „bez uposazenia, dom szpitalny mały, lecz dobrze zbudowany”. W r. 1665 szpital byl w stanie dobrym, w r. 1748 ,potrzebował naprawy", a w r. 1814 „był całkiem spróchniały”" W r. 1665 mieszkało w nim 8 ubogich, zaś w 1748 tylko 3.

I G. Eękawica. Bractwo Ubogich p.w. św. Łazarza erygował przy kościele paraf. kard. Zbigniew Oleśnicki, obdarzając je odpustami dnia 2 XII $1448{ }^{12}$. W r. 1516 pap. Leon X zatwierdził bractwo, które następnie wprowadził, przy okazji poświęcenia kościoła, bp sufr. krak. Paweł. Inne wzmianki: 1596, 1665, 1748.

1 CDPol. III $n r$ 95 s. 212-215.

2 ASang. II nr 76 s. 90 n. (Kupno wsi przez J. Tarnowskiego w dniu 17 II 1399). - Por. tamże, $V$ nr 40 s. 43 n. (20 X 1508 J. Tarnowski, wojew. sand., nadaje solectwo we wsi Cedrowi Kaczmirowskiemu).

3 K u m or Powstanie 1 rozwój siecis. 524

4 Wiz. 1596. - Conscriptio nr 94. - Por. Ku mor: Zanik I afiliacja s. 111. F. Herzig: Katedra s. 53 .

5 Schematismus dioec. Tarnoviensis 1863 s. 46.

$6 \mathrm{~K}$ u mor: Falsyfikaty s. 118.

7 Wiz. 1596-1748. - Conscriptio nr 94. - Por. F. Herzig, jw. s. 53.

8 Przekroje: 1536, 1581, 1596, 1665, 1748.

9 E a dogórskì: Studia s. 207.

10 Wiz. 1596-1748. - Elenchus omnıum parochiarum $1785 \mathrm{nr} 11$.

11 Specyfikacja 1814 s. 1.

12 Conscriptio nr 97 (reg.). - Wiz. 1596 i 1665 (reg.). 
I H. Szkoła parafialna w r. 1596 była w stanie dobrym. W r. 1665 wizytator nakazuje, „aby kantor z resztą służby kościelnej kształcił w szkole młodziez zdolną $i$, o ile mozna, napełniał ją naukami" 13. Innych wzmianek brak.

\section{PARAFIA P I OTR K O I CE (wieś)}

Zródła przekrojowe: LBD III s. 224; LR 1513 k. 23; LR 1527 k. 47'; Rej. pob. 1536 s. 548; LR 1539 k. 22; LR 1561 k. 34, Regestrum 1570 s. 193; LR 1577 k. 84'; Rej. pob. 1581 s. 264, Wiz. 1596 k. 21'-23; Syn. 1621 s. 28; Wiz. 1637 k. 374-374' Starowolski 1655 k. Es'; Wiz. 1664 s. 498-500, 541-542; Wiz. 1605 k. 13-14, Wiz. 1669 k. 9-10; Syn. 1711 s. 15; Wiz. 1748 k. 79-83.

Inne źród 1 a: ADT: 1. Fasc. Piotrkowice (or. i kop. XVI-XIX w.); 2. Liber documentorum ecclesiae paroch. Piotrkovicensis (1748); 3 . Conspectus fundatarurn missarum et dotationum ad ecclesiam Piotrkovicensem reperibilium 1865 . APar. w Piotrkowicach: Ksiega dokumentów (kopia fałsz. dokum. fund.). WAP Kraków: I. Castrensia Sandecensia. Relationes 133 s. 198-202 (Inwentarz dóbr ziemskich $\mathrm{z}$ 1676); 2. Castrensıa Pilsnensı. Relationes $11 \mathrm{nr} 67$ (1741); 3. Terrestria Pilsnensia. Relationes 112 s. 559-594. - Por, Katalog inwentarzy s. 33.

I A. Parafia fundacji rycerskiej, wydzielona $z$ okręgu parafialnego w Tuchowie, powstała ok. r. $1470^{1}$; w r. 1470 posiadała jeszcze charakter filialny w stosunku do parafii macierzystej w Tuchowie ${ }^{2}$. W r. 1513 miała pełne prawa parafialne. Rzekomy dokument fundacyjny parafii z 3 VI 1316, wystawiony przez Wacława Bonera, wojew. krak.(!), jest falsyfikatem ${ }^{3}$.

Patronat: szlachecki ${ }^{4}$.

I B. Okręg parafialny ${ }^{5} \mathrm{w}$ latach 1536 -1581 i 1748 obejmował wsie: Piotrkowice, Łowczów, Zabłędza i Karwodza; w r. 1596 i 1664 wymieniono nadto Ryże*. Rzekomy dokument fundacyjny parafii z ok. $1770 \mathrm{r}$. wymienia w granicach parafii: Piotrkowice, Zabłędza, Lowczów i Karwodża ${ }^{6}$.

I C. W r. 1637 parafia liczyła około 500 osób. W r. 1664 przystąpiło do komunii wielkanocnej z poszczególnych wsi: Piotrkowice - 75, Łowczów - 132, Karwodża - 131, Zabłędza - 75, Ryże - 42 osoby; łącznie 453 wiernych. W 1748 r. — 340 osób.

I D. Kościół parafialny, wzmiankowany przez Długosza, był w r. 1570 drewniany i konsekrowany. W r. 1575 wystawiono świątynię nową, prezbiterium i zakrystia murowane, reszta $z$ drzewa?. W r. 1596 była jeszcze niekonsekrowana. W r. 1637 zaznaczono, że część murowana jest z kamienia; kościól był konsekrowany.' W latach 1664-1699 był on częściowo murowany, częściowo drewniany, niekonsekrowany. W r. 1739 zanotowano: „Kościół - - na którym chór mały obalił się i mury obalone na ziemi lezą. Corpus drewniane funditus zgniło, ściany grzybami porosły i zgniły" 8 . W r. 1748 „kościół drewniany - całkowicie zrujnowany, rozpadł się".

13 Por. Kot: Szkolnictwo s. 314.

$1 \mathrm{Ku} \mathrm{mor:} \mathrm{Powstanie} \mathrm{i} \mathrm{rozwój} \mathrm{sieci} \mathrm{s.} 539$.

2 LBD III s. 224: Piotrkowice, villa habens in se ecclesiam parochialem, filiam ecclesiae paroch. in Tuchów.

3 Kum or: Falsyfikaty s. 119.

4 Regestrum 1570. - Wiz. 1596-1748.

5 Przekroje: 1536, 1581, 1596, 1664, 1748.

6 Liber documentorum s. 143-145. - Księga dokumentów (kopia).

7 Wiz. 1596 k. 21.

8 Liber documentorum s. 115 (Kopla wizytacji z 1739 r.). 
Nową świątynię w części drewnianą a w części murowaną „wybudowal na kilka lat przedtem miejscowy proboszcz".

Wezwanie: św. Michał archanioł ${ }^{9}$.

I $E_{1}$. Łowczów. Kaplica drewniana p.w. św. Jana Ewang. i św. Jana Chrzciciela, konsekrowana, istniała w r. 1596. W r. 1678 potrzebowała ona naprawy ${ }^{10}$. W r. 1731 wizytator polecil odbudować kaplice, kxtóra przed kilkoma laty została przez wichure całkowicie zniszczona" ${ }^{11}$. W r. 1739 zaznaczono, że „kościółek - - jest spadły, tylko locus ubi - - fuit" ${ }^{12}$. W r. 1748 podano, że ,kaplica była niegdyś, lecz została zniszczona przez wichury" Inne wzmianki: 1637, 1664-1669.

I F. Piotrkowice. W r. 1748 zaznaczają, że ,szpitala nie ma i nigdy nie było".

I G. Piotrkowice. Bractwo Niepokalanego Poczęcia NMP ufundował Franciszek Pisarzowski, legując na ten cel (15 XII 1736) 2000 fl. pol. ${ }^{13}$.

I H. Piotrkowice. Szkoła parafialna w 1596 r. ,była w stanie lichym, groziła upadkiem". Wizytator polecił naprawić szkołę. W r. 1665 i 1669 wizytator nakazał, by ,zdolniejsza młodziez - - chodziła do szkoły i ksztalciła się w naukach i śpiewie"; proboszczowi polecił utrzymywać w tym celu zdolnego bakałarza ${ }^{14}$. Ok. 1770 r. szkola istniała i posiadała dość bogate uposażenie ${ }^{15}$.

I $\mathrm{M}_{1}$. Piotrkowice. Prebenda fundi Piotrkowice uposażona została w r. 1487 przez Maneczkę z Wielogłów i jego żonę, miejscowych właścicieli $^{16}$. 21 IX i 1 X 1540 uposażenie prebendy zostało powiększone przez zapis $500 \mathrm{fl}$. pol. ${ }^{17}$. Inne wzmianki: 1513, 1539, 1561, 1596.

Patronat: szlachecki ${ }^{18}$.

I $\mathrm{M}_{2}$. Piotrkowice. Prebendę fundi Zabłędza uposażył w r. 1590 Stanisław Broniewski, właściciel Zabłędzy, przeznaczając na jej beneficłum 24 fl. pol. rocznych odsetek; erygował ją i obdarzył dziesięcinami bp krak. Piotr Myszkowski ( $\dagger$ 1591) ${ }^{19}$.

Patronat: szlachecki ${ }^{20}$.

I $\mathrm{M}_{3}$. Piotrkowice. Altarię p. w. Najśw. Maryi Panny w kościele paraf. ufundował 27 III 1706 Stanisław Burzyński, właściciel Piotrkowic, przeznając na ten cel $1000 \mathrm{fl}$. pol. ${ }^{21}$. Inne wzmianki: $1758{ }^{22}$.

Patronat: szlachecki ${ }^{23}$.

I N. Eowczów. Laskami słynący obraz św. Jana Ewang. znajdował się

9 Regestrum 1570. - Wiz. 1596-1748. - Elenchus omnium parochiarum $1785 \mathrm{nr} 10$.

10 Liber documentorum s. 78 (Ordinatio pro ecclesia in villa Piotrkowice 1678).

11 Tamze s. 109 (Ordinatio seu decretum reformationis pro ecclesia in Piotrkowice 1731).

12 Liber documentorum s. 116 (Wizytacja $\mathrm{z} 1739$ r.).

13 ADT: Fasc. Piotrkowice (kopla z XVIII w.).

14 Por. Kot: Szkolnictwo s. 316.

15 Informacje zawarte $w$ sfałszowanym ok. $1770 \mathrm{r}$. dokumencie fundacyjnym parafii. Zob. Liber documentorum s. 143-145 (kopia z 1859 r.).

16 Wiz. 1596 (reg.). - Liber documentorum s. 12 (reg.). - Conspectus 1865 s. 6. (reg.).

17 AOffic. vol. 71 s. 1123 i 1133.

18 Zob. przyp. $16 \quad 117$.

18 Wiz. 1596 (reg.). - Liber documentorum s. 12 (reg.). - Conspectus 1865 s. 6 (reg.).

20 Zgodnie $z$ prawami fundacji.

21 ADT. Fase. Piotrkowice (Informacje w dokum. z r. 1758 - kopia).

22 Tamze.

28 Zgodnie $z$ prawamı fundacji. 
w miejscowej kaplicy. Przy ołtarzu były liczne wota. Msze św. w kaplicy odprawiano bardzo często, ze względu na pobożność i pielgrzymki wiernych ${ }^{24}$.

V C. Zabłędza. Wiz. 1665 informuje, że „Piotr Broniowski, patron kościoła, został przeciągnięty przez żonę do sekty luterańskiej - - W dworze jego odbywają się schadzki luteran i kalwinów z ministrem Kałajem". Inna wzmianka: 1669 .

\section{PARAFIA PLEŚ N A (wieś)}

Źród la przekrojowe: MPV I i II (1327-1358); Gromnicki: Swiętopietrze s. 366 n. $(1328-1358,1373-1374,1551-1561)$, LBD II s. 275 ; Rej. pob. 1508 s. 466; LR 1513 k. 21; LR 1527 k. 43'; LR 1529 s. 70; Rej. pob. 1536 s. 546-547; LR 1539 k. 21; 1561 k. 98; Regestrum 1570 s. 194; LR 1577 k. 87; Rej. pob. 1581 s. 561 n.; Wiz. 1596 k. 20'-21'; Syn. 1621 s. 28; Wiz. 1637 k. 376'; Starowolski 1655 ks. $\mathrm{E}_{3}$; Wiz. 1664 s. 502-505; 542-544; Wiz. 1665 s. $14-15$; Wiz. 1669 k. 22-23; Syn. 1711 s. 15 ; Wiz. 1748 k. $74-78^{\prime}$.

Inne źródła: ADT: 1. Fasc. Pleśna (or. i kop. XVI-XIX w.); 2. Tabella beneficii parochiae Plesnensis a. D. 1814; 3. Relatio de statu parochiae Plesnensis de 18 I 1785. - WAP Kraków: 1. Castrensia Biecensia. Relat. 178 s. 544-547 (Inwentarz dóbr ziemskich 1635); 2. Castrensia Biecensia. Relat. 253 s. 559-594 (1741); 3. Terrestria Pilsnensia. Relat. $107 \mathrm{nr} 97$ (1772); 4. Terrestria Pilsnensia. Relat. 106 a nr 346 (1773); 5. Tamże. Relat. $107 \mathrm{nr} 130$ (1774); 6. Tamże. Relat. 113 nr 275 (1774); 7. Tamże. Relat. $111 \mathrm{nr} 91$ (1778); 8. Tamże. Relat. $112 \mathrm{nr} 195$ (1779); Tamże. Relat. $112 \mathrm{nr} 196$ (1779). - Por. Katalog inwentarzy s. 83 n. - Katalog Archiwum Aktów Dawnych Miasta Krakowa. T. 1. Kraków 1907 nr 332 s. 89 n.

I A. Parafia, fundacji rycerskiej, powstała ok. r. 1327; pierwsza wzmianka z r. $1327^{1}$. Rzekomy dokument fundacyjny z 1236 r. jest falsyfikatem ${ }^{2}$.

Patronat: szlachecki ${ }^{3}$.

I B. Okręg parafialny ${ }^{4}$ w r. 1536 obejmował wsie: Pleśna, Rychwałd, Łowczówek, (Eowczów Mniejszy), Woźniczna, Kłokowa, Rzuchowa, Lichwin i Cło. W latach 1581-1596-1665-1748 parafia obejmowała wsie wyżej wymienione bez Cla.

I C. Ludność parafii w połowie XIV w. szacuje się na 135 osób $^{5}$. W r. 1664 do komunii wielkanocnej przystąpiło łącznie 884 osoby, w tym z Pleśnej - 145, Rychwałdu - 137, Eowczówka - 130, Lichwina - 228, Rzuchowej - 125, Kłokowej 25 i Woźniczej - 94.

I D. Kośció1, parafialny, wzmiankowany w latach 1327-1358, był w r. 1570-1596-1637 drewniany i konserwowany. Ok. 1645 r. nową świątynię, również drewnianą, 'wybudowali Marcin Dobek Łowczowski i jego żona Wiktoria z Borowic ${ }^{\circ}$. W r. 1657 częściowo uległa ona pożarowi; odbudował ją ok. r. 1664 Mikołaj Dobek Lowczowski ${ }^{7}$. W latach 1669-1748 kościół był drewniany, niekonsekrowany.

24 Wiz. 1664: Altare - - s. Joannis Evang. dicunturque esse miraculosa, vota diversa plurima - - frequenterque 11 dicta capella missae peragi solent ex devotione populi ad has imagines confluentis.

\footnotetext{
$1 \mathrm{Ku} \mathrm{m}$ or: Powstanie i rozwój sieci s. 525.

2 Tabella 1114 s. 1. - Relatio 1785 s. 1 (falsyfikat S. Morawskiego).

3 Regestrum 1570. - Wiz. 1596-1748.

4 Przekrofe: 1536, 1581, 1596, 1664, 1748.

5 E a dogór k ki: Studia s. 201.

6 Wiz. 1664. - Por. Schematismus dioec. Tarnoviensis 1863 s. 26.

7 Schematismus 1863 s. 26.
} 
Wezwanie: Wszyscy Swięci ${ }^{8}$; św. Andrzej ap. (1570) ${ }^{9}$.

I E. Rzuchowa. Kaplica drewniana p.w. św. Stanisława b. i m. istniała przed r. $1635^{10}$. Po przejściu właścicieli Rzuchowej na kalwinizm kaplica została zdewastowana i pozostawiona bez kapelana. W r. 1664 ,dach na kaplicy zbutwiały, ściany zepsute, cały budynek w wypadku, gdy nie będzie naprawiony, grozi ruina.". W r. 1669 wizytator polecil proboszczowi przeprowadzić gruntowny remont kaplicy. W r. 1748 kaplica drewniana była w stanie dobrym; w pewne dni odprawiano w niej służbę Bożą.

I H. Szkoła parafialna w r. 1596 byla w stanie dobrym. Inne wzmianki: $1637,1665^{11}$.

V C. W r. 1664 wizytator zanotował, ze właściciele wsi Rzuchowej, Stanisław Kotkowski i jego żona, należą do Kościoła reformowanego (kalwinizmu).

\section{PARAFIA PORE B A A DLNA (wieś)}

Źródła przekrojowe: MPV II (1350-1358); Gromnicki: Swiętopietrze s. 366 n. $(1353-1358,1373-1374,1551-1556,1560-1562$; LBD I s. 605, 609; Re ]. pob. 1508 s. 467 ; LR 1513 k. 23; LR 1527 k. 48; LR 1529 s. 154 , Rej. pob. 1536 S. $547 \mathrm{nr} ., 551 \mathrm{n}$;; LR 1539 k. 22; LR 1561 k. 34; LR 1577 k. 85; Rej. pob. 1581 s. 262 n.; Wiz. 1596 k. $14-15^{\prime}$, Syn. 1621 s. 28 ; Wiz. 1637 k. 376-376'; Starowolski $1655 \mathrm{k} . \mathrm{E}_{3}{ }^{\prime}$, Wiz. 1664 s. 500-502, 556-558; Wiz. 1665 s. 17; Wiz. 1669 k. 10-12; Syn. 1711 s. 15 ; Wiz. 1748 k. 50-56.

Inne źródła: ADT: 1. Fasc. Poręba Radina (or. i kopia od XVI-XIX w.); 2. Tabella fundationum ecclesiae parochialis in Poręba Radlna a. D. 1864; 3. Tabella beneficii parochiae Poręba a. D. 1814;,4. Consignatio privilegiorum, documentorum et decretorum penes parochiam Porembiensem reperibilium a, D. 1840; 5. Inventarium beneficii parochiae in Poremba Radlna 22 IV 1784. - AKapT: Officialia Kazimierski $1587-1596$.

I A. Parafia, fundacji rycerskiej, powstała przed r. 1350; pierwsza wzmianka z r. $1350^{1}$. 5 VII 1776 bp krak. Ignacy Kajetan Sołtyk wcielił uposażenie parafii do drugiej kanonii kaznodziejskiej przy kolegiacie tarnowskiej i utworzył przy miejscowym kościele „wikarię wieczystą" 2. Parafii przywrócono dawne prawa parafialne około r. $1787^{3}$.

Patronat: szlachecki ${ }^{4} .9 \mathrm{~V} 1776$ Hieronim Sanguszko zrzekł się patronatu na rzecz kapituły kolegiackiej w Tarnowie ${ }^{5}$.

I B. Okręg parafialny ${ }^{6}$ w latach 1536-1748 obejmował: Porębę Radlną, Lękawkę, Swiebodzin, Nowodworze. W r. 1536 wymieniono nadto Zawadę j. Podgrodzie; w następnych latach wystepują one w granicach parafii Tarnów.

I C. Dla pierwszej połowy XIV w. Iudność parafii szacuje się na 165

8 Wiz. 1596-1748. - Elenchus omnium parocharum 1785 nr 5.

- Regestrum 1570 s. 191 (często informuje błędnie).

10 Wiz. 1664 s. 544: Capella —. - ab anmis 30 circiter vacat.

11 por. Kot: Szkolnictwo s. 317.

1 K u mor: Powstanie \& rozwóf s1ee1 s. 525.

2 AEp. Vol. 110 (Vialia. Vol. I. 1773-1777) s. 752-765. -.. Por. F. H e r z 1 g, jw. s. $93 \mathrm{n}$.

3 W latach $1783 / 87$ zostały zniesione na terenie zabora austriackiego beneficja proste.

4 Wiz. 1596-1748.

5 AEp. Vol. 110 (1773-1777) S. 756-759.

6 Przekroje: 1536, 1596, 1664, 1748, 1781. 
osób ? W r. 1664 do komunii wielkanocnej przystąpiło łącznie 682 wiernych z wyjątkiem 7, będących podówczas w karach kościelnych. Z poszczególnych wsi parafial. liczba osób była następująca: Poręba - 186, Łękawka - 182, Nowodworze - 59, Radlna - 147, Swiebodzin - 108. W r. 1748 ilość komunikujących na Wielkanoc wynosiła blisko 500 .

I D. Kościól parafialny, wzmiankowany w latach 1350-1358, by W 1596-1637-1664-1669 drewniany i konsekrowany. W r. 1748 zaznaczono, że ,jest bardzo stary i przez obecnego proboszcza gruntownie wewnątrz i zewnątrz odnowiony". W r. 1809 został wybudowany nowy kościól, również drewniany ${ }^{8}$.

Wezwanie: św. Piotr i Pawel apostołowie (1589-1785) ${ }^{\bullet}$.

I F. Poręba. Szpital, bez uposażenia, w r. 1664 „był w stanie grożące] ruiny". W r. 1667 szpitał otrzymał niewielkie uposażenie ${ }^{10}$. W r. 1748 zaznaczono, że ,budynek szpitala jest bardzo stary” W r. 1784 ,budynek szpitalny cały spróchniały" ". W r. 1813 miejscowy proboszcz wybudowal własnym nakładem nowy szpital ${ }^{12}$. W latach $1665-1748$ mieszkało w nim 4 ubogich.

I G. Poręba. Bractwo św. Anıołów Stróżów zcstało zaprowadzone w r. $1632^{13}$. 23 XI 1711 ks. Aleksander Dominik Lubomirski zapisał na rzecz bractwa rolę zwaną „Nosakowską i Kaczmarzewską" ${ }^{14}$. VIII 1721 Mikołaj Złotnicki, archidiakon sądecki, polecił wznowić bractwo, które było w upad$\mathrm{k} \mathrm{u}^{\mathrm{15}}$. Inne wzmianki: 1664, 1748.

I H. Poręba. Szkoła parafialna istniała w r. 1539 i $1587^{16}$. W r. 1596 była „szkoła w stanie lichym"; wizytator polecił ja naprawić. W r. 1665 i 1669 wizytator uskarżał się, że kierownik nie ma pilności $w$ nauczaniu młodzieży ${ }^{17}$. W r. 1721 szkoła istniała, kierownikiem szkoły by ${ }^{\ddagger}$ organista ${ }^{18}$. W r. 1748 domu dla kierownika szkoły nie było. Jeszcze W r. 1814 „szkoły normalnej" nie było ,ze względu na brak funduszów" 10.

\section{PARAFIA R ADGOSZCZ (wies)}

Źródła przekrojowe: Rej. pob. 1508 s. 487; Rej. pob. 1536 s. 497; Rej. pob. 1581 s. 260 (par. Dąbrowa Tarn.); ,Syn. 1711 s. 15; Wiz. 1748 k. $124-128$.

Inne źródła: ADT: 1. Fasc. Radgoszcz (or. i kop. XVII-XIX w.); 2. Index documentorum ecclesiae Radgoszczensis a. D. 1812.

Ważniejsze opracowania: Kumor: Zanik i afiliacja s. 117-118.

\footnotetext{
7 壬a dogór s k l. Studia s. 201.

8 Tabella $1814 \mathrm{nr} 7$. Ecclesia ante annos 5 est tota de novo constructa.

9 Officialia Kazimierski s. 46 (1589). - Wiz. 1596-1748. - Elenchus omnium parochırum 1785 nr 9.

10 Tabella 1864 s. 4.

11 Inventarium 1784 s. 19

12 Tabella 1814 nr 7.

13 Wiz. 1664.

14 ADT: Fasc. Poręba Radlna (kopia z XVIII w.).

15 Consignatio $1840 \mathrm{nr} 6$ (reg.). - ADT. Fasc. Poręba Radlna (Decretum reformation:s pro ecclesia paroch. Poręba Radina 1721 s. 1).

16 Officialia Kazimierski s. 38 (1587).

17 K o t: Szkolnictwo s. 317.

19 Decretum reformationis 1721 s. 1 . - Consignatio documentorum $1840 \mathrm{nr} 6$.

19 Tabella $1814 \mathrm{nr} 7$.
} 
I A. Wieś, wzmiankowana w r. 1508, należała do parafii w Dąbrowie Tarnowskiej. Parafię uposażył Jerzy hr. Lubomirski z Wiśnicza 11 II 1662 i tegoż dnia erygował ja bp sufr. krak. Mikołaj Oborski ,jako wikarię wieczystą i filię kościoła parafialnego w Dąbrowej"1. 27 II 1662 fundację zatwierdził król Jan Kazimierz ${ }^{2}$. W r. 1748 wizytator informuje, że „kościół w Radgoszczy, zwany filią Dąbrowy, został zamieniony na parafialny $z$ powodu duzej odległości do kościoła parafialnego i poważnej liczby wiernych" .

Patronat: szlachecki ${ }^{4}$.

I B. Okręg parafialny obejmował tylko wieś Radgoszcz ${ }^{5}$.

I C. W r. 1748 do komunii wielkanocnej przystąpiło 1747 osób.

I D. Kościół parafialny, drewniany, wybudował w r. 1661 Jerzy hr. Lubomirski; w r. 1663 konsekrował go bp sufr. krak. Mikołaj Oborski ${ }^{6}$.

Wezwanie: św. Kazimierz w. ${ }^{7}$; św. Katarzyna p. i m. (1785) ${ }^{8}$.

I F. Radgoszcz. Szpital zostal ufundowany 19 VIII $1745^{\circ}$. W r. 1748 mieszkało w nim 6 ubogich.

I H. Radgoszcz. O szkole parafialnej brak wzmianek.

\section{PARAFIA R ÝGLICE (wieś)}

Žródła przekrojowe: MPV II (1350-1358); Gromnicki: Swietopietrze s. 366 n. (1351-1358, 1373-1374, 1551-1560); LR 1513 k. 23; LR 1527 k. 47'; LR 1529 s. 96; I.R 1539 k. 22; LR 1561 k. 34; Wiz. 1565 s. 422 n.; LR 1577 k. 84'; Rej. pob. 1581 s. 112-113; Wiz. int. $1595 \mathrm{k} .153^{\prime}-155^{\prime}$; Wiz. ext. $1595 \mathrm{k} .111-112$; Wiz. 1596 k. $24^{\prime}$; Syn. 1621 s. 28 ; Rej. pob. 1629 s. 251, 258 n.; Wiz. 1637 k. 373-373'; Starowolski $1655 \mathrm{k} . \mathrm{E}_{3}^{\prime}$; Wiz. 1664 s. 491-494, 535-538; Wiz. 1665 s. 10-11; Wiz. 1669 k. 23-23'; Rej. pob. 1680 s. 283 n.; Syn. 1711 s. 15; Wiz. 1748 k. $90-95$.

In ne źródła: ADT: 1. Fasc. Ryglice (or. i kop. XVI-XIX w.); 2. Tabella ecclesiae parochialis Ryglicensis tt. S. Catharinae V. et M. a. D. 1814; 3 . Status beneficii in pago Ryglice a. D. 1784 descriptus. - WAP Kraków: Castrensia Biecensia. Relat. 232 s. $1554-1558$ (Inwentarz dóbr ziemskich z 1718 r.); Tamże. Relat. 240 s. 1115-1121 (1730); Tamże. Relat. 248 s. 1336-1344 (1738); Tamże. Relat. 253 s. 1023-1027; Tamże. Relat. 255 s. 497-498 (1744); Tamże. Relat. 263 s. $457-472$ (1752); Tamże. Relat. 278 s. $154-177$ (1778). Por. Katalog inwentarzy s. 7. Katalog Archiwum Aktów Dawnych Miasta Krakowa. T. 1. Kraków 1907 nr 332 s. $89 \mathrm{n}$.

I A. Parafia, fundacji rycerskiej Sulimów, powstała pod koniec pierwszej połowy XIV w. ${ }^{1}$; pierwsza wzmianka z r. $1350^{2}$. W XV w. parafii nie wymienia Długosz, ale wzmiankują o niej inne przekazy źródłowe ${ }^{3}$.

1 Index documentorum 1812 nr 1 (reg.). - ADT: Fasc. Radgoszcz (kopia z XVIII W.). Por. K u m o r. Zanik 1 afiliacja s. 118.

2 Index documentorum $1812 \mathrm{nr} 1$.

3 Por. Ku mor: Zanik i afiliacja s. 118. - Schematismus 1863 podaje (s. 37), że prawa paraf. nadano kościolowı w r. 1859.

4 Zob. przyp. 1. - Wiz. 1748.

5 Wiz. 1748.

6 Tamże.

7 Zob. przyp. 1, 5 .

8 Elenchus omnium parochiarum $1735 \mathrm{nr} 35$

9 Index documentorum $1812 \mathrm{nr}$ 10. - Wiz. 1748 (kopia).

1 W r. 1378 wlaścicıelem Reglic był ,Pasco de Riglicze". Zoh. CDT, I nr 103 s. 156 n. (10 II 1378).

2 I u mor: Powstanle i rozwój słeci s. 525. - Wizytacja z 1748 r. (k. 90) informuje, ze na mensie kamiennej wielkıego oltarza był wykuty następujący napis: „Wladislaus princeps Poloniac sub anno Domını 1308 wieś Burzyn i Rygielskıe Porzecze nadał wıecznymi 
Patronat: szlachecki ${ }^{4}$

I B. Okręg parafialny ${ }^{\jmath}$ w r. 1581 obejmował wsie: Ryglice Niższe, Ryglice Wyższe, Kowalowy, Gielowa, Joniny, Łyciąza (późn. Liciąż) i Unieszowa. W r. 1596 brak Łyciązy, ale wymieniono nadto Bestwieszowa (Bistuszowa) oraz tylko jedne Ryglice. W latach 1629 i 1680 występują: Ryglice Wyższe i Nizsze, Kowalowy, Gielowa, Unieszowa, Joniny i Łyciąza (brak Bistuszowej). W r. 1664 wymieniono nadto: polowa wsi Burzyn (druga polowa nalezy do par. Tuchów), Bistuszowa, Lipie, Podlasie, Gallia, Wizna (późn. Wisze ?), Kozłówek* i jedne Ryglice. W r. 1748 do parafii nalezały tylko: Ryglice, Joniny, Kowalowy, Gielowa, Uniszowa i Bistuszowa. W r. 1814 nie wymieniono Gielowej ${ }^{6}$.

I C. Dla pierwszej połowy XIV w. ludność parafii szacuje się na 225 osób ${ }^{7}$. W r. 1664 przystąpiło do komunii wielkanocnej łącznie 1449 wiernych, z czego na Ryglice przypadło 475, Unieszową - 95, Burzyn - 120, Bistuszową - 85, Joniny - 170, Kowalowy - 183, Gielową - 64, Lipie - 67, Łyciążę - 53, Podlasie - 27, Gallię - 60, Wiznę - 41 i Kozłówek - 9. W r. 1748 komunikujących na Wielkanoc było 1600. W r. 1814 liczba parafian wynosiła 2800 osób $^{8}$.

I D. Kościół parafialny, wzmiankowany w XIV i XV w., był w latach 1565-1596-1637--1665-1669 drewniany i konsekrowany. W r. 1748 podano, że „został zbudøwany w 1301. r. przez M. Burzyńskiego i W Kielanowskiego". W tymże roku ,był, z powodu starości, nadżarty przez ząb czasu, lecz po większej części przez obecnego proboszcza gruntownie przebudowany".

Wezwanie: św. Katarzyna p. i m. ${ }^{9}$.

I F. Ryglice. Szpital, bez uposażenia, w dobrym stanie, był już w r. 1595. W r. 1664 zaznaczono, że „dom szpitalny jest fundacji Łyczków”. W r. 1784 "mieszkanie na ubogich z gruntu spróchniałe, opustoszałe, koniecznie nowego potrzebuje wystawienia" ${ }^{10}$.

I G $\mathrm{G}_{1}$. Ryglice, Bractwo Różańca św. zostało zaprowadzone w r. $1613^{\mathbf{1 1}}$. 22 IV 1707 b.p chełmski i adm. diec. krak. Kazimierz Łubieński erygował specjalną kapelanię bracką ${ }^{12}$. Innt wzmianki: 1664, 1669, 1707, $1814^{13}$. (Por. I $\mathrm{M}_{2}$ ).

czasy szlachetnem dwıema osobom: Panu Mikolajowı Burzyńskiemu I P. Wawrzyńcowi Kielanowskıemu, którzy koścı́ł rygıelskı ufundowali, do którego najpıerwszego plebana introdukowali ks. Stanisława Pierzchale" - Por. Schematismus 1863 s. 27 n. - Schematismus 1875 s. 59. Dokument ten jest nieautentyczny.

3 J. Czubek: Katalog rękopısów Akademii Umıejętnoścı w Krakowie. Dodatek 1. Kraków $1912 \mathrm{nr} 32$ s. 63 (5 X 1430 - ks. Krystyn z Hyglic). - N i w ińs k 1: Archıwum s. 6 (kopia dokum. z 5 X 1430). - AOffic. Vol. 1 (1436-1453) s. 672 (24 XI 1453: Decima in Kowale ad ecclesiam in Ryglice). - Katalog Archiwum nr 332 s. 89 (reg. dokum. z 17 XII 1482).

4 AOffic. Vol. $4 \mathrm{ks}$. 103 (21 III 1474: Presentatio ad ecclesiam in Ryglice), - Vol. 24 s. 249 (15 I 1502: Johannes Kwiatkowsk1 haeres de Ryglicze collator et patronus ecclesiae parochialis in ibldem). - Wiz. 1565-1748. - Status 1784 s. 1.

5 Przekroje: 1581, 1595, 1629, 1664, 1680, 1748, 1814.

6 Tabella 1814 s. 1.

7 E a dogórsk1. Studia s. 201.

8 Tabella 1814 s. 1.

9 Wiz. 1565-1748. -- Elenchus omnium parochiarum $1785 \mathrm{nr} 14$.

10 Status 1784 s. 19.

11 Schematismus 1863 s. 30.

12 ADT. Fasc. Ryglice (dokum. pap.).

13 Tabella 1814 s. 1. 
I $G_{2}$. Ryglice. Bractwo św. Trójcy, wraz $z$ kapelania, ufundował ks. Walenty Wąsowicz, miejscowy proboszcz ${ }^{14}$; erygował je oficjał krakowski $15 \mathrm{XI} 1745^{1 \overline{5}}$. Inne wzmianki: $1814^{16}$.

I H. Ryglice. Szkoła parafialna była w r. 1527; w 15.95 ,w stanie niezbyt dobrym". W r. 1665 "szkoła niedawno postawiona"; do szkoły uczęszcza 15 chłopców ${ }^{17}$. Inna wzmianka: 1748 (scholares pauci).

I $\mathrm{M}_{1}$. Ryglice. Prebenda, nieznanego bliżej tytułu, ufundowana przez miejscowych właścicieli, istniała w r. 1637 Innych wzmianek brak.

Patronat: szlachecki ${ }^{18}$.

I $\mathrm{M}_{2}$. Ryglice. Prebendę dla kapelana bractwa Różańca św. uposażyli: Jan Podowski z Łowczowa, zapisując 26 VI 1708 na ten cel 1000 fl. pol., Adam Podowski, legując 24 IV 1708 na jej rzecz 750 fl. pol., oraz Urszula Potocka z Zimnejwodki, Kasper Wojakowski i Marianna Potocka z Ryglic, zapisując 31 X 1707 na ten cel 1000 fl. pol. a także rolę "Czamborówka" ${ }^{19}$; erygował ją 22 IV 1707 bp chełmski i adm. diec. krak. Kazimierz Łubieński ${ }^{20}$. (Por. I G G $_{1}$.

Patronat: szlachecki ${ }^{21}$.

I $\mathrm{M}_{3}$. Ryglice. Prebendę dla promotora bractwa Trójcy św. ufundował $19 \times 1745 \mathrm{ks}$. Walenty Wąsowicz, proboszcz w Ryglicach, który legował na ten cel 1801 fl. pol. ${ }^{22}$; erygował ją oficjał krakowski 15 XI $1745^{23}$.

Patronat: szlachecki ${ }^{24}$.

I N. Ryglice. W kościele paraf. znajdował się w r. 1664 ,łaskami słynący obraz NMP z Dzieciątkiem na ręku, pochodzenia greckiego, podobny do obrazu w Sokalu". Do obrazu pielgrzymują parafianie i obcy ${ }^{25}$.

\section{PARAFIA SKRZYSZÓW (wieś)}

Zródla przekrojowe: MPV II (1350-1358); Gromnicki: Świętopietrze s. 366 n. $(1352-1358,1373-1374,1551-1556)$; LBD I s. $605,609,611$; II s. 309 ; Rej. polb. 1508 s. 466 ; LR 1513 k. 22'; IR 1527 k. 46'; IR 1529 s. 181 ; Rej. pob. 1536 s. 545,550 ; LR 1539 k. 22; LR 1561 k. 33'; LR 1577 k. 84; Rej. pob. 1581 s. 264; Wiz. 1596 k. $7^{\prime}-9$; Syn. 1621 s. 28; Wiz. 1637 k. $375-375^{\prime}$; Starowolski $1655 \mathrm{k} . \mathrm{E}_{3}^{\prime}$; Wiz. 1664 s. 481-483, 527-529; Wiz. 1665 s. 6-7; Wiz. 1669 k. 21-21'; Syn. 1711 s. 15 ; Wiz. 1748 k. $28-33$.

In ne źródła: ADT: 1. Fasc. Skrzyszów (or. i kop. XVI-XIX w.); 2. Fasc. „Akta 1791"; 3. Tabella ecclesiae parochialis Skrzyszoviensis tit. S. Stanislai 1785; 4. Tabella beneficii parochialis Skrzyszoviensis 1812; 5 . Liber visitationum generalium ecclesiae parochialis Skrzyszoviensis ab an. 1748 (Wiz. 1748, 1763); 6. Fasc. Pogórska Wola (or. i kop. XVIII-XIX w.). - AKapT: Officialia Branicki 15991602. - APar. W Skrzyszowie: 1. Inventarium beneficii parochiae in Skrzyszów tit. S. Stanislai Ep. et M. de an. 1791; 2. Inscriptio susceptorum ad Confraternitatem S. Joseph ab an. 1750; 3. Album Ssmae Confraternitatis Patrocinii S. Joseph Sponsi BMV ab an. 1750 (współopr.); 4. Prothocollum omnium expeditionum tam

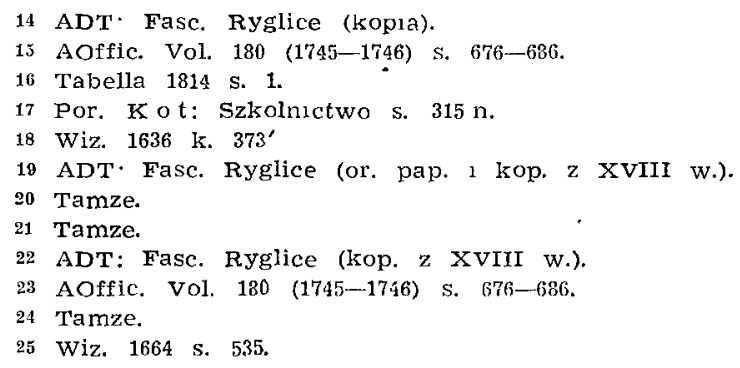


spiritualium, quam civilium - - ab 6 XI 1811 - parochiae Skrzyszoviensis pro usu ecclesiae suae confectum.

Wazniejsze opracowania: F. Herzig: Katedra s. 29 n. - Kumor: Zanik i afiliacja s. 110-111. - W. Demetryki ewi cz: [Sprawozdanie $z$ wycieczkı odbytej w swoim okręgu]. W: Teka grona konserwatorów Galicji Zachodnies. T. 1, Kraków 1900 s. 365.

I A. 17 VII 1331 ,haereditas Scrisew" przeszła drogą zamiany w posiadanie Spycimira, kasztelana krakowskiego ${ }^{1}$. Wieś lokował "na surowym korzeniu", na prawie niemieckim 4 V 1333 Spycimir, wojew. krak. 2. 11 V 1344 Kazimierz Wielki, na prośbę Spycimira, potwierdził nadanie prawa niemieckiego dla wsi ${ }^{3}$.

Parafię uposażył „jednym łanem ziemi” oraz innymi dochodami, 4 V 1333 wspomniany uprzednio Spycimir ${ }^{4}$. 12 V 1542 prymas Piotr Gamrat, jako bp krak., na prośbę Jana Amora Tarnowskiego, wcielił uposażenie parafii do kolegium wikariuszy kolegiaty tarnowskiej; w miejsce parafii utworzył on "wikarię wieczystą" . 19 V 1546 bp krak. Samuel Maciejowski potwierdził rozporządzenie poprzednika ". 16 IV 1791 miejscowość otrzymała z powrotem pełne prawa parafialne ${ }^{7}$. Rzekomy dokument fundacyjny parafii, wystawiony 28 IX 1313 przez Jacentego Działyńskiego, wojew. bracławskiego, jest falsyfikatem ${ }^{8}$.

Patronat: szlachecki (do 1542); 12 V 1542 abp P. Gamrat zatwierdził zrzezzenie się praw prezenty i patronatu przez Jana Amora Tarnowskiego na rzecz kolegium wikariuszy kolegiaty tarnowskiej ${ }^{\circ}$. 16 IV 1791 prawa patronackie przywrócono ks. Sanguszce ${ }^{10}$.

I B. Okręg parafialny za czasów Długosza obejmował $\mathrm{m}$. in. Skrzyszów i Podgórską Wolę. W r. 1536 wymieniono: Skrzyszów, Pogórza, Pogórska Wola. W r. 1581 - Skrzyszów, Wola Pogórska i Wołowice. W latach 1596-1664 w skład parafii wchodziły - Skrzyszów, Pogórza, Wola Pogórska i Wola Rzędzińska. W r. 1763 wymieniono: Skrzyszów, Wola Rzędzińska, Poszkole (późn. Pośkle), Wałki, Jodłówka czyli Granice, Wielkie Pole, Wola Pogórska, Pogórza, Bartynia * i Kobylarnia ${ }^{11}$.

I C. Dla połowy XIV w. ludność parafii szacuje się na 450 osób ${ }^{12}$. W r. 1664 do komunii wielkanocnej przystąpiło z całej parafii 1250 wiernych, w tym ze Skrzyszowa - 526, Pogórza - 51, Woli Pogórskiej - 224 i Woli Rzędzińskiej - 449. W 1763 r. - 2211 osób ${ }^{13}$. W r. 1812 tylko na terenie wsi Wola Pogórska, Wałki i Jodłówka mieszkało prawie 2000 ludzi ${ }^{14}$.

1 A.Sang. II nr 13 s. $16-17$.

2 ASang. II nr 14 s. $17-18$. KDMP, III $\mathrm{nr} 633$ s. 3.

3 CDPol. III nr 95 s. $212-215$.

4 Zob. przyp. 2. - Por. Ku mor: Powstanie I rozwój sieci s. 526.

5 ASang. $V$ nr 314 s. 338-343. - Por, F. Herzig: Katedra s. 29 n. - K u mor: Zanik I afiliacja s. 111.

6 A.Sang. $\mathrm{V} n \mathrm{nr} 341$ s. 375. - Por. F. Herzlg, Jw, s. 30.

7 ADT Fasc. „Akta 1791" (clok. pap.).

$8 \mathrm{Kumor}$ : Falsyfikaty s. 120.

B zob. przyp. 5-6. - Wiz. 1595-1748.

10 Zob. przyp. 7 .

11 Liber visitationum. - wiz. 1763 s. 38.

12 ta dogórski: Studia s. 201.

13 Wiz. 1763 s. 38.

14 Tabellạ 1812 s. 2. 
I D. Kościół parafialny pierwotny istniał już w r. $1333^{15}$. Nową świątynie, drewnianą wybudowano w r. $1514^{13}$. W latach 1596-1664 kościół był drewniany i konsekrowany. W r. 1747 został na nowo pokryty i naprawiony; fundamenty zbudowano $z$ drzewa dębowego i podciągnięto murem ${ }^{17}$.

Wezwanie: św. Stanisław b. i m. ${ }^{18}$.

I E. Wola Pogórska. Kaplica dworska przy majątku M. Siedleckiego, podstolego przemyskiego, istniała juz w r. $1763^{19}$. W r. 1778 Mikołaj i Józefa Siedleccy wybudowali drewniany kościół p. w. św. Józefa, który w ramach józefińskiej regulacji otrzymał prawa kapelanii lokalnej (po r. 1812) ${ }^{20}$.

I F. Skrzyszów. Szpital w r. 1596 stał blisko kościoła, był w stanie dość dobrym, bez uposażenia. Około 1651 r. uposażył go ks. Władysław Dominik Ostrogski ( $\dagger$ 1656) ${ }^{21}$. W r. 1664 był w stanie dobrym. W r. 1748 i 1763 zaznaczono, że „nie ma żadnej fundacji”. W r. 1664 mieszkało w nim 5 ubogich.

I G. Skrzyszów. Bractwo Opieki św. Józefa erygował, na skutek starań miejscowego proboszcza, ks. Bartłomieja Barańskiego, 13 XI 1749 pap. Benedykt XIV bullą Cum sicut accepimus. 5 III 1570 udzielif bractwu dalszych przywilejów i potwierdził jego erekcję bp sufr. krak. Michał Kunicki ${ }^{22}$.

I H. Skrzyszów. Szkoła parafialna w r. 1596 ,była w stanie niezbyt dobrym". Szkoła istniała w latach 1602, 1664, $1748^{28}$. W r. 1763 zaznaczono, j.e „dom szkolny jest podzielıny na dwie czéści: mieszkanie organisty i szko1ę" ${ }^{24}$. Powstały ok. 1770 r., sfalszowany dokument fundacyjny parafii wymienia bogate uposażenie szkoły ${ }^{25}$.

VI C. Skrzyszów. W r. 1763 na terenie parafii mieszlało, łącznie z dziećmi, 15 żydów ${ }^{26}$.

\section{PARAFIA SZYN W A $€ D$ (wieś)}

Źródła przekrojowe: MPV II (1350-1358); Gromnicki: Swiętopietrze s. 368 n. $(1352-1358,1373-1374,1551-1553)$; LBD I s. 605,609 ; Rej. pob. 1508 s. 466; LR 1513 k. 22'; LR 1527 k. $46^{\prime}$; LR 1529 s. 189; Rej. pob. 1536 s. 550 n.; LR 1539 k. 22; IR 1561 k. 33'; LR 1577 k. 84; Rej. pob. 1581 s. 264; Wiz. 1593 k. $9-10^{\prime}$; Syn. 1621 s. 28 ; Wiz. 1637 k. 375 ; Starowolski 1655 k. E $\mathbf{E}_{3}^{\prime}$; Wiz. 1664 s. $486-489,531-553$; Wiz. 1665 s. $8-9$; Wiz. 1669 k. $19^{\prime}-21$; Syn. 1711 s. 15 ; Wiz. 1748 k. $34-39$.

Inne źródła: ADT: 1. Fasc. Szynwałd (or. i kop. XVII-XIX w.); 2. In-

15 KOMP, II $\mathrm{nr} 633$ s. 3: „Damus eciam ecclesı ibidem - - unum laneum circa ecclesiam situm" (4 V 1333).

10 Wiz. 1748 podaje napıs umieszczony nad drzwıamı kościoła: „Haec ecclesia constructa est a. D. 1514 in laudem Deo et S. Stanislar Mart. - Joannes Czechow". - Por. Liber visitationum. - Wiz. 1763 s. 35. - Tabella 1785 s. 1. - Inventarium 1791 s. 1.

17 Wiz. 1748 .

18 Wiz. 1596-1748. - Wiz. 1763. - Tabella 1785 s. 1. - Elenchus omnium parochrarum

$1785 \mathrm{nr} 13$.

10 Wiz. 1763 s. 38.

20 ADT: Fasc. Pogórska Wola (Conspectus ecclesiae fil. in Pogórska Wola 1906 s. 2). Tabella 1812 s. 1.

21 AOffic. Vol. 134 (pod 8 III 1651: Ingrossatio documenti pro hospitale pauperum Skrzyszoviensi. Rpsu brak w AKMK. Regest podano wedlug Indeksu). - Wiz. 1664, 1748.

22 Inscriptio 1750 s. 9-10 (dok. papleski), s. 11 (dok. bpa Kunickiego). - Inventarium 1791 s. 13.

23 Officialia Branıcki s. 100-103 (1602). - Por. K ot: Szkolnictwo s. 314.

24 Wiz. 1763 s. 39.

25 ADT- Fasc. Skrzyszów (dok. perg. $41 \times 26,5 \mathrm{~cm}$, bez pieczęc1 i sznura)

20 Wiz. 1763 S. 38. 
ventarium ecclesiae Szynwaldensis et beneficii a. D. 1783 descriptum; 3. Summarium iurıum et documentorum ecclesiae parochialis Szynvaldensis a. D. 1783 descriptum (współopr.); 4. Conspectus fundatarum missarum ac devotionum penes ecclesiam parochialem in Szynwałd a. D. 1864; 5. Fasc. Tarnów (Conscriptio z końca XVIII w.). - APar. w Szynwałdzıe: 1. Kronika parafialna (Liber memorabilium od r. 1832), 2. Liber documentorum ad ecclesiam Szynwald 1839 comparatus; 3. Descrıptio - - reddituum ecclesıae in Szynwald dioecesis Cracoviensis in decanatu Tarnoviensı (1782?).

Ważnie jsze opracowania: Ks. F. Kokoszka: Szynwałd, pow. Tarnów. Odpisy i notatkı. Zebrał... Wroclaw 1954. (APar. W Szynwałdzie).

I A. Wieś została lokowana na prawie niemieckim przez Spycimira, wojew. krak., najpóźniej $11 \mathrm{~V} 1344^{1}$. Parafia, fundacji Leliwitów - Tarnowskich, powstała w latach 1344-1350; pierwsza wzmianka w r. $1350^{2}$. Rzekomy dokument fundacyjny parafii, wystawiony w $1323 \mathrm{r}$. przez Janusza Ocieskiego, wojew. braclawskiego, jest falsyfikatem ${ }^{3}$.

Patronat: szlachecki ${ }^{4}$.

I B. Okręg parafialny $w$ latach 1536-1783 obejmował jedną wieś Szynwałd ${ }^{5}$.

I C. Ludność parafii w połowie XIV w. szacuje się na 450 osób ${ }^{6}$. w r. 1536 mieszkało $w$ parafii 54 rodzin kmiecych i 3 zagrodników, zaś w r. 1596 60 kmieci. W r. 1664 do komunii wielkanocnej przystąpiło 713 osób starszych i 132 dzieci. W r. 1783 ludność parafii wynosiła łącznie 1100 osób ?

I D. Kościól parafialny wzmiankowany w latach 1350 - 1358, był 15961669 drewniany i konsekrowany. W r. 1748 zaznaczono, że „obecny pleban wsparł kościół murem". W r. 1776 częściowej reparacji kościoła dokonał ks. Józef Niedźwiecki, kan. tarnowski i proboszcz w Szynwałdzies.

Wezwanie: Wszyscy Swięci ${ }^{9}$.

I F. Szpital istniał już w r. 1659; w tym roku J. i K. Zamoyscy legowali na rzecz ubogich $\mathrm{w}$ szpitalu 25 fl. pol. ${ }^{10}$. W r. 1748 szpital ,stal na gruncie kościelnym, bez uposażenia"; mieszkało w nim 5 ubogich.

I G. Szynwałd. Bractwo Szkaplerza sw., wraz z kapelanią, erygował 13 VIII 1659 bp krak. Andrzej Trzebicki ${ }^{11}$. Inne wzmianki: 1665, 1669, 1748, $1783^{12}$. (Por. I M).

I H. Szynwałd. Szkola parafialna w r. 1596 ,była w stanie dobrym". 13 VIII 1659 bp krak. A. Trzebicki zatwierdził legat Jana i Katarzyny Zamoyskich, w sumie $60 \mathrm{fl}$. pol., ,dla kierownika szkoły, aby uczył młodzież”; fundatorzy zobowiązali każdorazowego promotora bractwa szkaplerznego, by „ubogim scholarom dawał obiady" ${ }^{13}$. W r. 1665 ,szkoła potrzebowała naprawy". Inne wrmianki: $1637,1669^{14}$.

$1 \mathrm{CDP}$, III nr 95 s. 212-215.

2 K u mor: Powstanie i rozwój stecı s. 526.

$3 \mathrm{Ku} \mathrm{m}$ or: Falsyfikaty s. 120.

4 Wíz. 1596-1748. - Inventarıum 1783 s. 1.

5 Przekroje: 1536, 1581, 1596, 1664, 1748, 1783.

6 Ea dogór s ki: Studia s. 201.

7 Inventarium 1783 s. 4.

8 Descriptio 1782 s. 2.

9 Wiz. 1596-1748. - Inventarıum 1783 s. 1. - Elenchus omnium parochiarum $1785 \mathrm{nr} 15$.

10 ADT: Fasc. Szynwałd (dokum. $z$ 13 VIII 1659 - 1kopia).

11 AEp. Vol. 59 (1658-1659) s. 279-292.

12 Inventarium 1783 s. 4. - Summarium 1783 s. 7.

13 ADT: Fasc. Szynwałd (kop.).

14 Por. Kot: Szkolnictwo s. 315. 
I M. Szynwald. Prebendę dla promotora bractwa szkaplerznego ufundował ks. A. Sławik, kanonik tarnowski i proboszcz w Szynwałdzie, zapisując na ten cel 14000 fl. pol.; 6 VII 1659 bp krak. A. Trzebicki wyznaczyl pelnomocnika do przeprowadzenia spraw związanych $\mathrm{z}$ fundacja ${ }^{15}$. 13 VIII 1659 tenże biskup erygował prebendę przy oltarzu M. B. Szkaplerznej ${ }^{16}$. 28 V 1760 bp krak. Ignacy Kajetan Sołtyk zatwierdził legat Franciszka Szwarcenberga Czernego, kasztelana wojnickiego, w sumie 26000 fl. pol., uczyniony na rzecz prebendy ${ }^{17}$. Inne wrmianki. 1664, 1665, 1669, 1748.

Patronat: szlachecki ${ }^{18}$

TARNÓW (miasto)

PARAFIA SW. M A R C I N A

Źródła przekrojowe: zob. par. Narodzenia NIMP; nadto: IMPV II s. 428 MPV I (1325-1342); II (1345-1353); Gromnicki: Swiętopietrze s. 366 n. (Tarnowiec - 1327-1358, 1551-1562) ${ }^{1}$; LBD I s. 604; Wiz. 1668 s. 558-560.

Inne źródła: zob. Tarnów - parafia Narodzenia NMP.

Ważniejsze opracowania: zob. Tarnów - parafia NMP.

I A. Pierwsze wiadomości o osadzie "Tarnów Wielki" podaje dokument kard. Idziego z 1123/25, wymieniajacy $\mathrm{m}$. in. Tarnów w granicach posiadłości opactwa tynieckiego ${ }^{2}$. Następne wzmianki występują w podejrzanej bulli pap. Grzegorza IX z $26 \mathrm{~V} 1229^{3}$ i transumpcie Bolesława Wstydliwego z r. $1275^{4} .21 \mathrm{~V} 1327$, tytułem zamiany za wieś Dębno i za dopłatą 40 grzywien, Leliwita Spicimir nabył od Łabędziów część Tarnowa Wielkiego, będąc uprzednio w posiadaniu części drugiej ${ }^{5}$. 24 IV 1328 Władysław Łokietek nadał Spycimirowi na własność "Tarnów Mały” i zezwolił na lokację obydwu wsi (,Tarnów Wielki” i „Tarnów Mały") na prawie niemieckim ${ }^{6}$. 7 III 1330 tenże monarcha na prośbę Spycimira, podniósł ,Tarnów Wielki" do godności miasta i obdarzył go prawem niemieckim na wzór Krakowa?

Parafia fundacji benedyktynów tynieckich powstała najpóźniej w XII w. i została ulokowana przy kościele św. Marcina b. i w. na terenie wsi Zawada ${ }^{8}$; pierwsza wzmianka $w$ r. 1325. 17 IV 1400 bp krak. Piotr Wysz, na prośbę Jana Tarnowskiego, wojew. sandomierskiego, zniósł parafię św. Marcina i. przyłączył ją do kolegiackiej w Tarnowie, a z jej beneficjum erygował

15 AEp. Vol. 59 (1658-1659) s. 270-272.

16 AEp. Vol. 59 s. 279-292. - ADT. Fasc. Szynwald (kopia) z 1798 r.). - Summarium Lurium 1783 s. 7 (kopia). - Descriptio 1782 s. 2 (reg.). - Conspectus 1864 s. 16-20.

$17 \mathrm{ADT} \cdot$ Fase. Szynwald (kopia z 1784 r.).

18 zob. przyp. 16.

1 Prawdopodobnie przekaz błędny.

$2 \mathrm{CDT}$, I nr 1 s. 1-8. - MPH, I s. 516-520. - CDP, III nr 1-3 s. 1-3. - Por. Z. K o z$10 \mathrm{w} \mathrm{k}$ a-B udk owa: Repertorium polskich dokumentów doby plastowskıej. Z. 1. Kraków $1937 \mathrm{nr} 26$ s. $29-33$.

$3 \mathrm{CDT}$, I nr 11 s. 21-23 (podrob.). - Por. Hirszberg: Stosunki osadnicze s. 33.

4 MPH, I s. 516-520 (podejrzany).

5 ASang. II nr 9 s. $11-12$.

6) ASang. II $\mathrm{nr} 11$ s. $13-15$.

7 ASang. II $\mathrm{nr} 12$ s. $15-16 .-\mathrm{AGZ}, \mathrm{V}$ nr 1 s. $1-2$.

8 Kumor: Powstanie i rozwój siec1 s. 519; M. A d a m c z y k: Początki Tarnowa s. 42. 
prałaturę kantorię przy tejże kolegiacie ${ }^{9}$. W miejsce zniesionej parafii erygował bp Wysz "wikarię wieczysta", a duszpasterstwo przy niej zlecił kapłanowi z kolegium wikariuszy kolegiackich ${ }^{10}$. Zgodnie z zarządzeniem bpa krak. Tomasza Strzępińskiego (1458) służba Boża w parafii została ograniczona do „mszy św. i kazania w niedziele i święta" i zlecona całemu kolegium wika- riuszy kolegiackich ${ }^{11}$. Prawdopodobnie od czasów kasaty kolegiaty i jej dawnego ustroju (1786) zaprzestano odprawiania tu nabozeństw ${ }^{12}$.

Patronat: klasztorny, następnie rycerski ${ }^{13}$.

I B. Okręg parafialny pierwotny stanowiły zapewne wszystkie wioski późniejszej parafii kolegiackiej ${ }^{14}$. Wizytacja $1664 \mathrm{r}$. informuje, że ,do tego kościoła, jak mówi tradycja, $\mathrm{z}$ dawna należały liczne wsie, odległe na kilka mil, lecz z biegiem czasu otrzymały one szereg wlasnych kościołów parafialnych".

I C. Dane demograficzne: zob. Tarnów - parafia Narodzenia NMP.

I D. Kościół parafialny, wzmiankowany od r. 1325, nazwany jest przez Długosza „kaplicą" "r. Przypuszcza się, że pierwotny kościół został zniszczony $\mathrm{w}$ czasie napadu Tatarów w r. $1287^{16}$. Być może z początkiem XV w. - uległ zniszczeniu pierwotny kościół drewniany na szczycie góry św. Marcina. $\mathrm{Na}$ jego miejscu postawiono obecny o konstrukcji zrębowej" ${ }^{17}$. W r. 1597 zaznaczono, że kościół „znajduje się obok zamku we wsi Zawada, że jest drewniany i konsekrowany". Wr. 1664 wizytator zapisał, że ,był to dawny kościól parafialny, zbudowany od niepamiętnych czasów z drzewa modrzewiowego - - i poświęcony, jak glosi tradycja, przez św. Stanisława bpa krak." Te same informacje powtórzył bp krak. Konstanty Felicjan Szaniawski w r. 1725.

Wezwanie: św. Marcin b. i w. ${ }^{18}$.

\section{TAR NÓW (miasto)}

\section{PARAFIA W NIEBOWZIECIA NMP}

Źródła przekrojowe: zob. par. Narodzenia NMP; nadto: MPV II s. 428, 436 (1353-1355); III s. 418 (1363); LBD I s. 604; Wiz. 1664 s. 563 n.

In ne źródła: zob. Tarnów - parafia Narodzenia NMP.

Ważniejsze opracowania: M. Król: Kościolek Najśw. Maryi Panny na Burku. Tarnów 1854; inne opracowania: zob. Tarnów - parafia Narodzenia NMP.

I A. Długosz, w informacjach o początkach kolegiaty tarnowskiej, pisze, że „Piotr Wysz —- erygowal w 1400 r. w mieście Tarnowie kolegiatę

- ASang. II nr 80 s. 94-97. - LBD, I s. 604 n. - Por. F. Herzig: Katedra s. 10 n. S. K l jak: Piotr Wysz bıskup krakowski. Kraków 1933 s. 76 . - K u mor: Zanik i afiliacja s. 16. - Tenze: Najstarsze parafie s. 272.

10 Tamze.

11 LBD, I s. 606. - Wiz. 1665. - Por. K u m o r Zaník I afiliacja s. $106 \mathrm{n}$.

$12 \mathrm{~K}$ u m or: Zanik i afiliacja s. 107 .

13 Klasztorny - zgodne z prawamı fundacji i własnośc1; rycerski - moze od lat 1327/30, kıedy Tarnów stał sıę własnością Leliwitów. - Por. ASang. II nr 80 s. 94-97.

14 Por. Ks. B. IK u m o r: Najstarsze parafie s. 272.

15 LBD, I s. 606.

16 J. E. D u t kie wı c z: Tarnów s. 28.

17 Tamze s. $35 \mathrm{n}$.

18 ASang. II nr 80 s. 94-97 (1400). - LBD, I s, 606, - Wiz. 1597-1725, 
z trzech kościołów parafialnych" '. Dokument erekcyjny kolegiaty z 17 IV 1400 wymienia trzy kościoły: Narodzenia NMP, wyniesiony do godności kolegiaty, św. Marcina „sub castro Tarnoviensi” i „capellam sanctae Mariae castri Tarnovensis" 2. Trzecia zatem parafia tarnowska była związana z kaplica grodowa ${ }^{3}$.

Kaplice tę, wraz z zamkiem, wybudował ok. 1330 r. wojew. krak. Spyci$\operatorname{mir}^{4}$. $13 \mathrm{~V} 1331$ bp krak. Jan Grot kaplicę tę poświęcił, udotował i erygowal ${ }^{5}$. Od początku posiadała ona charakter parafialny; każdorazowy kapelan winien posiadać święcenia kapłańskie, rezydować na miejscu, „tamquam si ad parochialis ecclesiae regimen fuisset assumptus". Prawa parafialne kaplicy jasno określił bp krak. Bodzanta w dokumencie z 16 VI 1362; obejmowały one mieszkańców zamku (rodzina Leliwitów i czeladź) ${ }^{6}$. 25 IX 1363 pap. Urban V obdarzył kaplicę zamkowa odpustami ${ }^{7}$; podobne odpusty przydzielił w 1385 r. kard. Demetrius, abp ostrzyhomski i prymas Węgier ${ }^{8}$. 17 IV 1400 bp krak. Piotr Wysz, na prośbę Jana Tarnowskiego, patrona kościoła zniósł parafię „na zamku", a z jej uposażenia utworzył beneficjum kanonii prebendarskiej tyt. „NMP na zamku tarnowskim” przy kolegiacie tarnowskiej ${ }^{\text {. }}$.

Patronat: szlachecki ${ }^{10}$.

I B. Okręg parafialny obejmowal mieszkańców zamku tarnowskiego ${ }^{11}$.

I C. Dane demograficzne: zob. Tarnów - parafia Narodzenia NMP.

I D. Kaplice murowaną wybudował ok. 1330 r. Spycimir, wojew. krak.; poświęcenia jej dokonał $13 \mathrm{~V} 1331 \mathrm{bp}$ krak. Jan Grot ${ }^{12}$. Kaplica istniała w latach 1354, 1355, 1362, 1385, 1400, 1470, 1513, 1529, 1539, 1561, $1577^{13}$. Wiz. 1597-1725 kaplicy "na zamku" nie wymieniają.

Wezwanie: Najśw. Maria Panna ${ }^{\mathbf{1 4}}$.

I M. Tarnów - ,na zamku”. Altarię p. w. św. Krzyża i Najśw. Maryi Panny ufundował w r. 1362 Rafał Tarnowski; 16 VI 1362 bp krak. Bodzanta udotował altarię dziesięcinami i erygował ${ }^{15}$. 17 IV 1400 została ona wcielona, wraz z kaplicą, „do uposażenia kanonii prebendarskiej na zamku tarnowskim" przy kolegiacie tarnowskiej ${ }^{16}$.

Patronat: szlachecki ${ }^{17}$.

1 LBD, I s. 604.

2 ASang. II $\mathrm{nr} 80$ s. $94-97$.

3 Ks. B. $\mathrm{K}$ u m or Najstarsze parafie s. 274.

4 J. E. D utk 1 e w $1 \mathrm{cz}$, Jw. s. 24.

5 zbiór dokumentów katedry i diecezji krakowskiej. Cz. 1: 1063-1415. Wyd. S. In u r a ś. Lublin 1965 ar 38 s. 52-53. (Maternaty do dzzejów Koścıoła w Polsce. T. 1).

6 CDMP, III nr 751 s. 153-154: Volumus autem et statuimus de cetero observandum, ut is, cui praedicti altaris regimen seu cura animarum antecessorum ipsius domini Raphaelis supradicti, culus et successorum Iuerit commissum - - ad sacerdotii gradum statutis temporibus infra spacium unius anni se faclet promoveri, tamquam si ad parochialis ecclesiae fuisset assumptus".

7 MPV, III $\mathrm{nr} 442 \mathrm{~s}, 418$.

8 CDMP, III nr $940 \mathrm{~s}$. 366.

- ASang. II nr 80 s. $94-97$. - Por. F. H e r z 1 g, jw. s. 22. - Ks. B. Ku m or Najstarsze parafie s. 274.

10 Por. przyp. 5-9.

11 Zob. przyp. 6.

12 Zob. przyp. 5.

13 Za lata: 1362, 1385, 1400 - zob. przyp. 6-9.

14 zob. przyp. 1-9.

15 CDMP, III nr 751 s. $153-154$.

16 Zob. przyp. 2.

17 Zob. przyp. 15. 
T A R N Ó W (miasto)

\section{PARAFIA NARODZENIA NMP}

zródła przekrojowe: MPV II (,Nova civitas”-1350-1358), III s. $312 \mathrm{n}$. (1346); Gromnicki: Swiętopietrze s. 366 n. (Nova civitas" - 1328-1358, 1373-1374, 1551-1562 ${ }^{1}$; LBD I s. $3,259,604-616$; II s. $6,7,305$; III s. 479 n.; LR 1513 k. $21^{\prime}-22^{\prime}$; IR 1527 k. 45 ; LR 11529 s. $73,111,118,123,136,152,153,180,310$; Rej. pob. 1536 s. 549-550; LR 1539 k. 21'-22; LR 1561 k. 33', LR 1577 k. 83-83'; Rej. pab. 1581 s. 258, 269; Wiz. 1597 s. 273-314; Syn. 1621 s. 24, 26, 28; Wiz. 1664 s. 558-564, Starowolski $1655 \mathrm{k} . \mathrm{B}^{\prime} ; \mathrm{B}_{4} ; \mathrm{C}_{2}$; $\mathrm{E}_{3}{ }^{\prime}$; Syn. 1711 s. $15 ; 1725$ s. 61-74, k. 237-246; Wiz. 1725 druk. s. 9-22.

Inne źródla: ADT: 1. Fasc. Tarnów (or. i kop. XV-XIX w.); 2. Conscriptio erectionum, privilegiorum ac munimentorum Ecclesiae Collegiatae Tarnoviensis ( $z$ końca XVIII w.); 3. Opisanie osiadłości miasta Tarnowa oraz innych wsi $i$ ich danin i powinności pro anno 1742; 4. Acta actorum officialatus perpetui Tarnoviensis vol. I $(1655-1695)$; 5 . Acta actorum officialatus perpetui Tarnoviensis vol. II (1763-1764); 6. Status Psalteriae Ecclesiae Collegiatae Tarnoviensis in dioecesi Cisvistulana Cracoviensi existentis (1780); 7. Status canonicatus tit. Transfigurationis Domini et S. Joseph in Ecclesia Collegiata Tarnoviensi existentis, concionaturae 2-ae (1780?); 8. Conspectus supressarum fundationum ac devotionum ad ecclesiam olim collegiatam Tarnoviensem ex an. 1848 confectus per Antonium Antałkiewicz; 9. Conspectus suppressarum fundationum - - 1879; 10. Specificatio realitatum et servitutum Coloniae Academicae Tarnoviensis et Canonicatus S. Joannis Cantii 1784; 11. Testis - omnia privilegia, erectiones, inscriptiones, fundationes, proventus, obligationes ac alia documenta Communitatis Vicariorum perpetuorum Ecclesiae Collegiatae Infulatae Tarnoviensis concernentia, demonstrans, per - - Blasium Josephum Barczykiewicz - - a. D. 1763 descriptus; 12. Index proventuum universorumque ad Communitatem R.R. Vicariorum perpetuorum Tarnoviensium a. D. 1752; 13. Regestrum expensarum pro necessitatibus communibus Communitatis Vicariorum Tarnoviensium - a. D. 1763 inchoatus. - AKapT: 1. Acta R. D. Christophori Kaz.1mierski praepositi perpetuique officialis Tarnoviensis - $-a b$ an. 1585-1599; 2. Acta R. D. Gasparis Branicki praepositi perpetuique officialis Tarnoviensis - - a. 1599-1602; 3. Acta perpetui Officialatus Tarnoviensis a. D. 1602 sub - - praesidentia Adm. R. D. Alberti Ziemięczki, praepositi ac perpetui officialis Tarnoviensis. - Państwowe Muzeum Ziemi Tarnowskiej w Tarnowie: Pergaminy (maszynopis znajdujący się w ADT). - AKapSand.: Acta Officialatus Sandomiriensis, $\mathrm{nr} 116$ (1642-1647). - Archiwum Prowincji OO. Bernardynów w Krakowie (Archiwum Klasztoru OO. Bernardynów w Tarnowie, depozyt): 1. Sygn. XIV-a-1: Archivium Conventus Tarnoviensis PP Bernardinorum collectum, et scriptum a. D. 1656 per P. Danielem Zielinski - - sub M. V.P. Antonio Szumlański guardiano; 2. Sygn. XIV-a-2: Archivium Conventus Tarnoviensis Patrum Obesrvantium regulae S. P. Francisci ab an. 1656 ex antiquo collectum ac in meliorem formam cum evidentioribus documentis deductum, cui addita sunt etiam vetustissima, quae inveniri poterant, et in a. D. 1770 per A.R.P. Joannem Capistranum Szydlowski - - conscriptum; 3. Sygn. XIV-e-2: Liber continens in se susceptos in Confraternitatem confratres et consorores BMV Immaculatae Conceptionis ex fundatione gen. d. F. Stępkowski fundatoris huius confraternitatis sub praesidentia P.A.V. Theophili Ciszkowski a. D. 1718; 4. Sygn. I: Regestr wpisowania person duchownych do Bractwa S. Franciszka, który się poczyna od roku 1603 - - ; II: Regestr wpisowania braciey i sióstr do Bractwa Anny Świętej Samotrzeciej; 5. Sygn. XIV-e-7: Księga Bractwa św. Franciszka w kościele Bernardynów w Tarnowie (1688-1719); 6. Sygn. XIV-f-1: Inventarium

1 Prawdopodobne przekaz błędny. 
sacrorum vasorum, praetiosorum et apparamentorum ecclesiae monasterii sub tit. M. V. Mariae ad Nives in civitate Tarnów religiosorum Barnardinorum (17851825); 7. Sygn. XIV-h-1: Akta różne klasztoru Bernardynów w Tarnowie (14991938), - Por. O. H. E. W y czaw ski OFM: Katalog Archiwum Prowincji OO. Bernardynów w Krakowie. Arch. Bibliot. kośc. T. 5: 1962 s. 101-115. Biblioteka Zakładu Narodowego im. Ossolińskich we Wrocławiu: 1. Sygn. 9633/III: Erectio Coloniae Academicae Tarnoviensis et Canonicatus Beati Ioannis Cantii in iudicio curiae episcopalis Cracoviensis (17 III 1760); 2. Sygn. 9711/III: Acta Coloniae Academicae Tarnoviensis XVIII saeculi.

Inwentarze miasta Tarnowa z XVI wieku. Wyd. J. Leniek. Tarnów 1908. (Odb. ze Spraw. Dyr. CK. Gimn. I w Tarnowe). - Kronika OO. Bernardynów w Tarnowie. Wyd. J. Leniek. Tarnów 1894. (Odb. ze Spraw. Gimn. Tarnowskiego). - Materiały źródlowe do dziejów miasta Tarnowa. Wyd. J. Leniek. Tarnów 1897. (Odib. ze Spraw. Gimn. Tarnowskiego). - Ks. Chrościńskiego Kronika $\mathrm{z}$ lat $1784-1794 \mathrm{z}$ przydaniem aktów fundacyjnych kolonii akademickiej w Tarnowie z lat 1559 i 1578 , jako też raportu o jej stanie z r. 1766 . Wyd. J. L en i e k. W: Archiwum do dziejów literatury $\imath$ ośwzaty $w$ Polsce. T. 9. Kraków 1897 s. 295-401. - Reformatio Ecclesiae Collegiatae Tarnoviensis - - a. D. 1597. Wyd. ks. F. M a ch a y: Dzialalność duszpasterska kard. Radziwiłła biskupa krakowskiego (1591-1600). Kraków 1936 s. 98-104.

Ważniejsze opracowania: M. A d a mczyk: Początki Tarnowa. Lublin 1955 (Maszynopis. Archiwum KUL). - Tenże: Początki Tarnowa. Spraw. KUL. Nr 13": 1963 s. 101-104. - W. B a 1i ck i: Miasto Tarnów pod względem historycznym i topograficznym. Tarnów 1831. - M. B a lińs ki: Spytko z Melsztyna i jego ród. Bibliot. warsz. T. 3: 1886. - Z. C zapska, W. Dolarowski: Rynek w Tarnowie. Warszawa 1954. - Katalog Zabytków sztuki w Polsce. T. 1: Województwo krakowskie. Z. 13: J. D u $t \mathrm{k}$ i e w i c z: Powiat tarnowski. Warszawa 1953. S. Dutkiewicz: Dawne cechy tarnowskie. Tarnów 1896. - F. Herzig: Katedra, niegdyś kolegiata $w$ Tarnowie. Tarnów 1900. - K u mor: Dzieje. Ks. B. Ku u or: Najstarsze parafie Tarnowa. Currenda. R. 108: 1958 s. 270-275. J. Le n i ek: Historia kolegiaty tarnowskiej. Tarnów 1902. (Odb. ze Spraw. Gimn. Tarnow.). - J. Leniek, F. Herzig, ks. F. Leśniak: Dzieje miasta Tarnowa. Tarnów 1911. - A. P is z o w a: W 600-lecie Tarnowa. Tarnów 1930. - F. Her zi g: Miasto Tarnów. Tarnów 1911. - Ks. J. R z e pa: Konsystorz generalny w Tarnowie (1781-1785). Nasza Przeszlość. [T.] 7: 1958 s. 139-179. - Z. Sim.c he: Tarnów i jego okolica. Tarnów 1930. - Słown. geogr. T. 12 s. 197-204. M. A. T u rkowski: Spicimir, herbu Leliwa, kasztelan krakowski, założyciel Tarnowa i Melsztyna. Lwów 1876. - L. Z arewicz: Leliwita Spicimir, kasztelan krakowsiki praojciec Melsztyńskich i Tarnowskich (1312-1352) oraz monografia Melsztyna. Kraków 1890. - Teka Grona Konserwatorów Galicji Zachodniej. T. 1. Kraków 1900 (indeks). - J. Dutki e wi cz: Katedra w Tarnowie. Currenda. R. 108: 1958 s. 258-263. - F. K ę d zie rski: Pięciowiekowy jubileusz Zakonu OO. Bernardynów w Tarnowie. Currenda R. 110: 1960 s. 221-226. - J. E. Dutki ewicz: Tarnów. Warszawa 1954.

I A. 7 III 1330 Władysław Eokietek, na prośbę Spycimira, wojew. krak., podnićsł "Tarnów Wielki" do rzędu miast i nadał mu prawo niemieckie 2. Po lokacji miasta w Tarnowie osada w latach 1330-1346 otrzymała druga i trzecią parafię, fundacji wspomnianego Spycimira, wojew. krak."; pierwsza wzmianka w r. $1346^{4}$.

17 IV 1400 bp krak. Piotr Wysz, na prośbę Jana Tarnowskiego, wojew. sandomierskiego, zniósł tytuł plebanalny i wyniósł kościół parafialny p. w.

\footnotetext{
2 ASang. II nr 12 s. 15-16. - AGZ, V nr 1 s. $1-2$.

$3 \mathrm{~K} \mathrm{u} \mathrm{mor}$ Powstan1e I rozwój sieci s. 526. - M. A da m c z y k, jw. s. 40.

4 MPV, III s. 313.
} 
Narodzenia NMP do godności kolegiaty ${ }^{5}$. Erekcję kolegiaty potwierdził w r. 1418 pap. Marcin V". Pap. Pius VI, bullą In suprema beatı Petr Cathedra z 13 III 1786, zniósł kolegiatę a świątynię wyniósł do godności kościoła katedralnego dla diecezji tarnowskiej $i .24$ IX 1805 pap. Pius VII, bulla Operosa atque indefessa, w związku ze zniesieniem diecezji tarnowskiej, odebrał świątyni range kościoła katedralnego, pozostawiając jej tylko tytuł parafii ${ }^{8}$. Wobec starań ks. Sanguszki († 1813) Gubernium Lwowskie, dekretem z 16 IX 1808, zadecydowało, że kolegiata nie będzie przywrócona ${ }^{9}$. Tytuł katedry przywrócił kościołowi pap. Leon XII, bullą Sedium episcopalium translationes (23 IV 1826), po wznowieniu diecezji tarnowskiej ${ }^{10}$.

Patronat: szlachecki ${ }^{11}$.

I B. Okręg parafialny ${ }^{12}$ za czasów Długosza obejmował miasto Tarnów z przedmieściami oraz wsie: Grabówka (Grabarka), Rzędzin, Gumniska, Krzyż, Klikowa i Tarnowiec. W r. 1536 nie wymieniono Grabówki i Krzyża. W r. 1581 do parafii nalezały: miasto Tarnów z przedmieściem, Wola Rzędzińska, Tarnowiec, Klikowa, Zabłocie, Gumniska, Grabówka, Krzyż, Pogwizdów, Rzędzin, Wola Tarnowska, Zawada, Podgrodzie, Konary i Nieczajna. W r. 1725 wyliczono: miasto Tarnów, Jerzyn*, Rzędzin, Gumniska, Zawada i Tarnowiec.

I C. Ludność parafii w połowie XIV w. szacuje się na 1515 osób ${ }^{13}$. W r. 1662 samo miasto Tarnów liczyło mieszkańców $768^{14}$. W r. 1820 ludność miasta wynosiła 2136 osób, Przedmieścia - 2274, Zabłocia - 536, Pogwizdowa - 438, Strusiny - 1325, Grabówki - 796 i Terlikówki - $135^{15}$.

I D. Kościół parafialny, murowany, późniejsza kolegiata i obecna katedra, wedlug Długosza zostal zbudowany przez Spycimira jeszcze za panowania Władysława Eokietka $(\dagger 1333)^{16}$. Według innych początki świątyni sieggają ostatnich lat XIV stulecia ${ }^{17}$. W XV i XVI w. świątynia została rozbudowana; „bazylikowy kościół, z jedną, wysoką wieżą na osi, przedstawiał

5 ASang. Ir nr 80 s. 94-97. - LBD, I s. 604-615. - J. D I u g o s z: Historia Poloniae. Ed. A. Przeźdzle ckl. T. 3. Cracoviae 1876 s. 542. - Rozbiór krytyczny Annalium Poloniae Jana Długosza z lat 1385-1444. T. 1. Oprac. S. G a w ę d a [i in.]. Wroclaw 1961 s. $60 .-$ S. K1 Jak: Piotr Wysz biskup krakowskı. Kraków 1933 s. 76. - F. H erzig: Katedra s. $10 \mathrm{nn}$.

a Akapsand. nr 116 Acta officialatus Sandomirensis (1642-1647) k. 30'-36' (kopia insertowana do dokumentu z 1416 r.). ADT. Conscruptio nr 1 (reg.). - Testis nr 1 s. 3 (reg.).

$7 \mathrm{Kum}$ or Dzieje nr 5 s. 111-127.

8 Tamze, nr 14 s. $141-146$.

- ADT. Fasc. "Acta 1808" (dokum. oryg.).

$10 \mathrm{Ku}$ m o r: Dzleje nr 21 s. 159-162.

11 zob. przyp. 4-5, 9. - Wiz. 1597-1725.

12 Przekroje LBD, 1536, 1581, 1725.

13 Eadogórski: Studia s. 201.

14 A. Pa wi ń ski: Polska XVI wieku pod względem geograficzno-statystycznym. T. 3: Małopolska. Warszawa 1886 s. 52. - Por. J. L en 1 ek, F. H e r z lg, ks. F. L eśni a k: Dzıeje s. 38.

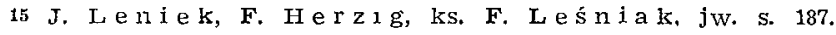

16 LBD, I s. 604. - Por. ks. B. K u m or: Najstarsze parafie s. 272.

17 J. D u tki e w 1 c z: Katedra w Tarnowie s. 258. - J. Dutkiewicz (Tarnów s. 37) pisze: ,,budowa koścloła trwała przez cały wiek XV i została ukończona doplero w pierwszej ćwiercı XVI w.". - KS. F. L eśn i a k: Artystyczne I historyczne zabytki miasta Tarnowa. W: J. Lentek, F. Herzıg, ks. F. Lesinak: Dzieje mıasta Tarnowa s. 280: „z końca XIV, lub początku XV wieku", - F. Herzig: Katedra s. 9. 
typ raczej rzadki na terenie Małopolski" ${ }^{18}$. W r. 1597 był on „murowany i konsekrowany"; wizytator polecił kapitule troszczyć się o „należyte utrzymanie i pokrycie kościoła" oraz reparację okien. W r. 1725 była ,świątynia konsekrowana, a jej budynek murowany, roboty starodawnej". Wizytator nakazał, by ze względu na starożytność i dostateczną wielkość budynku kolegiaty - - pokryé cały jej dach dachówka ceglaną, a nie gontami drewnianyni". Większą przebudowę budynku kościoła przedsięwzięto na początku i przy końcu XIX stulecia ${ }^{19}$.

Wezwanie: Narodzenie Najśw. Maryi Panny ${ }^{\mathbf{2 0}}$.

$\mathrm{E}_{1}$. Tarnów. Kościół i konwent franciszkanów p. w. Trójcy Przenajśw. zamierzał wybudować Rafał Leliwita Tarnowski ok. 1360 r.; 2 XII 1359 uzyskał on od pap. Innocentego VI zezwolenie na wybudowanie kościoła i klasztoru dla 12 zakonników ${ }^{21}$. Fundacja ta jednakże, z nieznanych powodów, nie doszła do skutku. W r. 1459 Jan Amor Tarnowski, wraz z bratem, sprowadzili bernardynów do Tarnowa i wystawili dla nich drewniany klasztor $z$ kościołem za murami miasta ${ }^{22}$. W 1468 r. Jan Amor Tarnowski, kaszt. krak., w miejsce drewnianego wybudowal murowany kościół i klasztor, które jednocześnie zostały otoczone murem obronnym ${ }^{23}$. 23 XI 1499 fundator klasztoru i kościoła wydał dokument, zatwierdzający uposażenie dla konwentu ${ }^{24}$. Wlatach 1664-1702-1725 „kościół był murowany z cegły i konsekrowany" ${ }^{25}$. W r. 1786 ces. Józef II skonfiskował kościół i klasztor, które $w$ dalszej kolei losu zostały zamienione na sąd; zakonnicy przeniesieni do klasztoru bernardynek ${ }^{26}$. W r. 1725 przebywało w klasztorze około 15 zakonników.

Wezwanie: Najśw. Maryja Panna Śnieżna ${ }^{27}$.

I $E_{2}$. Tarnów. Konwent bernardynek (siostry pokutujące lub koletki) drewniany, został zbudowany ,blisko murów cmentarza" prawdopodobnie

18 J. Dutkiewlez: Kateđra s. 258. - J. E. Dutkiewiez: Tarnów s. 37. Ks. F. L és n i a $k$, jw. s. $280 \mathrm{n}$.

19 F. H e r z $1 \mathrm{~g}$ : Katedra s. $150 \mathrm{nn}$.

20 MPV, III s. 418 (1363). - ASang. II nr 80 s. 94-97 (1400). - LBD (1470). - Wiz. 15971725. - Elenchus omnium parochiarum $1785 \mathrm{nr}$ 1. - Tytuł koścıola występuje prawle we wszystkıch cytowanych niżej przekazach źródłowych.

21 VMPL (Vetera Monumenta Poloniae et Lithuaniae. Ed. A. Theiner. T. 1. Romae 1860), I nr 792 s. 590.

22 LBD, III s. 479 n. - APBern. Sygn. XIV-a-1. Archivium Conventus Tarnoviensis - 1656 s. 19. - Sygn. XIV-a-2: Archivium Conventus Tarnoviensis - - 1656-1770 s. $1 . \quad-$ O. Cz. B og d a ls k l OFM. Bernardynı w Polsce 1453-1530. T. 1. Kraków 1933 s. 172, 202.

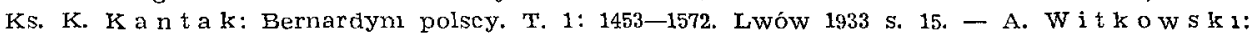
500-lecie klasztoru OO. Bernardynów w Tarnowie. Currenda. R. 110: 1960 s. 221.

23 APBern. Sygn. XIV-a-1: Archlvium Conventus Tarnoviensis - -1656 s. 257: „Circa annum 1468 nova fecit fundamenta pro ecclesia murata, quam et perfecit Joannes Amor in Tarnov castellanus Cracoviensis". - Por. przyp. 22. - J. E. Du t k 1 e w 1 c z: Tarnów s. 40.

24 APBern. Sygn. XIV-a-2: Archivium Conventus Tarnoviensis 1656-1770 s. 3-4 (kopza). Por. F. H e r zig: Katedra s. 39 n. (dokum. w jęz. pol.).

25 Wiz. 1664 S. 563 n. - APBern. Sygn, XIV-11-1: Akta rózne klasztoru Bernardynów w Tarnowie (1499-1938) s. 171: Wizytacja z 14 II 1702. - Wiz. 1725 s. 67.

26 Ks. K. K a n t a k: Bernardynı polscy. T. 2: 1573-1795-1932. Kraków 1933 s. 562. A. W 1 t k o s k i, Jw. S. 223. - F. Herzag, Jw. s. 47, 148.

27 Wiz. 1597-1725. - APBern. Sygn. XIV-a-1 s. 171 (1702). - Sygn. XIV a-2 s. $3 \mathrm{nn}$ 11499). F. Pohol c ck 1. Catalogus diplomatum Bibliotlicea Instituti Ossolinianı nec non Bibliotlecae Pawlikovianae (1227-1505). Lwów $1937 \mathrm{nr} 288$ (dok. z $10 \mathrm{~V}$ 1506). - AKapT: Officialia Kazimıersk1 s. 56 (1591), $77^{\prime}$ (1597). 
przez Tarnowskich w r. $1550^{28}$. Dopiero od r. 1634, po dokonaniu reformy koletek i zaprowadzeniu klauzury, pomyślano o wystawieniu osobnego kościoła dla zakonnic. Wybudowano go w r. $1647^{29}$. W latach 1664 i 1725 ,,kościół był częściowo murowany, częściowo drewniany, konsekrowany”. W r. 1747 ks. P. K. Sanguszko zezwolił na budowę murowanego klasztoru i kościoła $z$ materiałów rozebranego zamku tarnowskiego ${ }^{30}$. W latach $1752-1776$ budowy dokonała ks. Barbara Sanguszkowa ${ }^{31}$. 25 VII 1783 ces. Józef II, po przeniesieniu zakonnic do Nowego Sącza, oddał klasztor i kościół bernardynom ${ }^{3 *}$. W r. 1656 były w klasztorze 24 zakonnice ${ }^{33}$, w r. $1725-10$. Wezwanie: św. Michał Archaniol ${ }^{34}$; św. Barbara p. i m. (od r. 1776) ${ }^{35}$.

I $\mathrm{E}_{3}$. Tarnów. Kościół św. Marcina b. i w., drewniany i konsekrowany, dawny parafialny: zob. Tarnów - parafia św. Marcina.

I $\mathrm{E}_{4}$. Tarnów. Kaplica p. w. Najśw. Maryi Panny „na zamku tarnowskim, murowana i konsekrowana, dawna ,parafia zamkowa": zob. Tarnów - parafia Najśw. Maryi Panny.

I E. Tarnów. Kościól p. w. Wniebowzięcia NMP, drewniany, został zbudowany ,przez sześciu wieśnıaków z Przedmieścia Większego" przed r. $1458^{36}$. W r. 1597 byl on "drewniany i konsekrowany". 15 XII 1621 bp krak. Marcin Szyszkowski erygował kanonię p. w. Wniebowzięcia NIMP „na Burku” przy kolegiacie tarnowskiej, zlecając jej kanonikowi opieke nad kościołem 1 odprawianie w niej służby Bożej ${ }^{37}$. Według ks. Leśniaka „,pierwotny budynek kościoła miał spłonąć w XVII w." Odbudował go ks. Andrzej Tarło 38 . W latach 1664-1725 kościól był drewniany i konsekrowany.

I E $E_{6}$. Tarnów. Kościół p. w. Trójcy Przenajśw. „na Terlikówce”, drewniany wystawił w r. 1527 mieszczanin Adam Eberhard ${ }^{30}$. Nowy, również drewniany, zbudował w r. 1589 ks. Eukasz Godzinka, wikariusz kolegiaty tarnowskiej; konsekrował go w 1597 r. kard. Jerzy Radziwiłł ${ }^{40}$. W r. 1597 zanotowano, że ,kaplica została niedawno zbudowana, na miejscu dawnej, i. konsekrowana przez kard. Radziwiłła". W r. 1664 podano, że „została inkorporowana do kolegium wikariuszy kolegiaty tarnowskiej; służbę Bożą

28 APBern. Sygn. XIV-a-1. Archivium Conventus Tarnoviensis 1656 s. $4 . \quad$ Por. F Herzig, jw. S. 46. - Informacje J. E. Dutkıewicza (Tarnów s. 64) jakoby klasztor został wybudowany ok. 1680 r., wobec weześniejszych relacji, sa nie do przyjęcıa.

29 Ks. K. K a n ta k: Bernardyn1. T. 2 S. 359, 367. - Archiwum miasta Tarnowa (Maszynopis w ADT. Cz. 2 s. 21 - dokum. z 22 VII 1647) kaze się domyślać 1stnienia kościoła.

30 F. Herzlg, jw. S. 46. - J. E. D u t k 1 e w 1 e z: Tarnów s. 70

31 Ks. F. Leśn 1 a k, Jw. s. 295. - F Herzig: Katedra s. 47. - J. E. Dutkiew I c z: Tarnów s. 64 .

32 zob. przyp. 26. - J. L en 1 e k: Tarnów za czasów Leliwitów. W: J. Lenıek, F. Herzıg, Fs. F. Leśnıak: Dzreje miasta Tarnowa s. 52.

33 APBern. Sygn. XIV-a-1: Archivium - - 1656 s. 4. - wiz. 1597-1725. - Archiwum miasta Tarnowa. Cz. 1 s. 21 (dolsum. z 22 VII 1647).

34 Wiz. 1597-1725. - APBern. Sygn. XIV-a-1. Archivium Conventus Tarnoviensis 1656 s. 4.

35 F. H e r z 1 g: Katedra s. 47.

30 F H erzlg, jw. 38 n. - J. E. Dutkle w l c z: Tarnów s. 40. - Ks. F. L eśni a k, JW. s. 54 .

37 Conscruptio nr 99 (reg.). - Por. F. H e r z l g, jw. s. $51 \mathrm{nn}$.

38 Ks. F. L eśn n a k, jw. s. 293 n. - J. E. Dutkiewicz (Tarnów s. 40) uwaza, że kościór ,zachował sıę $w$ niewiele zmienıonym stanıe do naszych czasów".

30 J. L e n i e k: Tarnów za czasów Leliwitów s. 55. - J. E. Dutkıewicz (Tarnów s. 77) odnosi te dane do kościola św. Anny.

40 J. L en lek (Tarnów s. 55) podaje date budowy na r. 1562. - F. He rzig, Jw. S. 49. - J. E. D u k k e w $1 \mathrm{cz}, j w$. s. 77. 
odprawia się w niej raz w tygodniu". W r. 1725 kościółek był drewnianýy i konsekrowany.

I E $E_{7}$ Tarnów. Kościól p. w. św. Anny, drewniany, mieszczący ok. 40 osób, wybudował w r. 1527 Adam Eberhard, mieszczanin tarnowski, jako wotum za uratowanie życia; $29 \times 1529$ został on poświęcony ${ }^{41}$. W r. 1597 ,kaplica była drewniana, konsekrowana, nieuposażona". W r. 1654 wójt tarnowski, Kilian Batkowicz, przy pomocy kolegium wikariuszy kolegiaty, wybudował nową świątynię murowaną ${ }^{42}$. Służbę Bozą spełniali w kościółku wikariusze kolegiaty. Wiz. 1664 i 1725 nie wymieniaja kościoła. 9 I 1789 Cyrkul tarnowski zwrócił się do miejscowego konsystorza o przekazanie kościoła na użytek świecki. 13 I 1789 konsystorz odwołał się w tej sprawie do Gubernium Lwowskiego ${ }^{43}$. W r. 1821 kościół został rozebrany ${ }^{44}$.

I E $E_{8}$. Tarnów. Kościól szpitalny p.w. Ducha Sw. (Zob. I F).

I E. Tarnów. Kaplica p. w. "Ciemnicy Pana naszego Jezusa Chrystusa", murowana, koło klasztoru bernardynów, została wybudowana w r. 1654, "nakładem różnych dobroczyńców”, przez ks. Antoniego Szumlawskiego, miejscowego gwardiana. Nabożeństwa odprawiano tu w każdą środę i piątek ${ }^{45}$. Innych wzmianek brak.

I F. Tarnów. Kościół szpitalny, drewniany, p. w. Ducha Swiętego, św. Krzyża, św. Jana Chrzciciela, św. Dziesięciu Tysięcy Męczenników Żołnierzy, św. Leonarda Wyznawcy, św. Zofii z Córkami, św. Apolonii i Otylii, wybudowali w r. 1448 Jan Czapnik burmistrz, Jan Hensel kuśnierz, Grzegorz Szewc, Marcin Rubens i Jan Karlicza, rajcy Tarnowa. 27 II 1448 fundatorzy kościoła legowali na rzecz probostwa szpitalnego 8 grzywien rocznych odsetek i ,dom z ogrodem przy rzeczonej kaplicy" ${ }^{46}$. 8 V 1448 kard. Zbigniew Oleśnicki, bp krak., zatwierdził fundacje i erygował przy kościele prepozyturę szpitalną ${ }^{47}$. W r. 1597 ,kościół był drewniany i konsekrowany". Przed r. 1664 wybudowano świątynię nowa, ,murowaną z cegły" 48. Inne wzmianki: 1513, 1527, 1529, 1539, 1561, 1577, 1585, 1725 ${ }^{49}$. 9 I 1789 Cyrkuł tarnowski zwrócil się do konsystorza biskupiego w Tarnowie o przekazanie kościoła na cele świeckie ${ }^{50}$. W czasie wojny tureckiej (1787-1788) kościół zamieniono na magazyn wojskowy, po wojnie zaś przeznaczono na ,sale teatralną". 19 XII 1791 ostatecznie zadecydowano o jego przeznaczeniu na użytek świecki ${ }^{51}$. W latach $1810-1821$ kościół został rozebrany ${ }^{52}$. (Zob. I $F_{8}$ ).

41 F. H e rzig, jw. s. 47 n. (dokum. w jęz, pol.). - J. L c n i e k, Jw. s. 55. - J. E. Du tk i e w i c z, jw. s. 77 .

42 F. Herzig, Jw. 48 . - J. E. D t kiew $1 \mathrm{ez}, \mathrm{jw}$. s. 77.

43 ADT: Fase. "Acta 1789" (dokum. pap.).

44 J. E. D u tkie wi c z, Jw. S. 77.

45 APBern. Sygn. XIV-a-2: Archivium Conventus Tarnoviensis 1656-1700 s. 266.

46 Muzeum Miejskre poz, 165 (dokum. perg. o wym. $19 \times 26,5 \mathrm{~cm}$ ). - Por. F. H e rzig, Jw. S. $25 \mathrm{n}$. (dokum. w jęz. polskım). - Pozostałe źródła podają wezwanıe koścıoła. Duch Swıęty.

47 F. Pohorecki: Catalogus diplomatum nr 150 s. 49. - AGZ, IV nr 88 s. 157-159.

48 Wiz. 1664 s. 560. - J. Lenıek (Tarnów s. 53) oraz J. E. Dutkiewicz (Tarnów s. 77) podaja błędnie, że stało się to w XVIII w.

4B Officialia Kazımerski k. 23' (1585: Institutio hon. Sebastianı Marek, vicarii Tarnoviensis ad ecclesiam hospitalem S. Spiritus extra muros Tarnovienses). - Akta wizytacji 1725 S. 16.

50 ADT. Fasc, "Acta 1789" (dokum. pap.).

51 AD'T: Fasc. "Acta 1791" (dokum. pap.),

52 J. E. D u t kiew d c $z$, jw. s. 77 . 
Patronat: rada miasta Tarnowa ${ }^{53}$; dokument z 17 i 18 I 1515 przyznal patronat nad kościołem „Łukaszowi, wikariuszowi tarnowskiemu” ".

Szpital, przypuszczalnie fundacji mieszczańskiej, istniał przed r. $1448^{5 \check{5}}$. W r. 1458 bp krak. Tomasz Strzępiński zatwierdził na rzecz szpitala zapis, zabezpieczony na jatkach rzeźniczych w mieście ${ }^{50}$. W r. 1521 otrzymał on szereg przywilejów gospodarczych ${ }^{57}$. W r. 1664 „,szpital był w stanie dobrym”, na uposażenie posiadał 4 łany ziemi. W r. 1725 wizytator nakazał prepozytowi rewindykację należnych szpitalowi czynszów. W r. 1664 mieszkało w szpitalu ,19 debilów, ubogich kobiet, tylko 3 mężczyzn”. Inne wzmianki: jak ,kościól szpitalny”.

I $\mathrm{G}_{1}$. Tarnów. Bractwo Literackie NMP przy kolegiacie istniało w XVI i pierwszej połowie XVII stulecia ${ }^{58}$. Można przypuszczać, ze zaprowadził je ks. Marcin de Lubsycz, który od 1406 r. był kapelanem, altarii takiegoż bractwa w Pilźnie, a w r. 1415 został prepozytem kapituły tarnowskiej ${ }^{\text {59. }}$. Innych wzmianek brak.

$I G_{2}$. Tarnów. Bractwo Bozego Ciała przy kolegiacie istniało już zapewne w XV w. ${ }^{60} \mathrm{~W}$ latach 1517 i 1540 papieże Leon X i Pawel III obdarzyli bractwo odpustami ${ }^{61}$. 30 VIII 1651 bp krak. P. Gembicki erygował kapelanię bracką jako altarię secundi mnnsterii przy ołtarzu Bożego Ciała ${ }^{62}$. Inne wzmianki: 1685, $1725^{63}$. (Por. I $\mathrm{M}_{9}$ ).

$\mathrm{I} \mathfrak{G}_{3}$. Tarnów. Bractwo św. Anny przy kolegiacie zostało zaprowadzone najpóźniej w r. 1514; w tym bowiem roku otrzymało własnego kapelana ${ }^{64}$. 29 X 1654 bp krak. Piotr Gembicki erygowal „dla wygody bractwa” kapelanię secundi ministerii p. w. św. Agnieszki p. i m. przy ołtarzu i w kaplicy brackiej p. w. św Anny ${ }^{65}$. (Por. I $\mathrm{M}_{10}$ ).

$I_{4}$. Tarnów. Bractwo Szkaplerza św. przy kolegiacie erygowal, wraz z kapelanią, $29 \mathrm{~V} 1654$ bp krak. Piotr Gembicki ${ }^{66}$. Inne wzmianki: 1657, 1660, $1741^{67}$. (Por. I M 11 ).

$\mathrm{I}_{5}$. Tarnów. Bractwo św. Anny przy klasztornym kościele NMP Śnieżnej zostało zaprowadzone w r. 1598, za zezwoleniem kard. Jerzego Radziwiłła ${ }^{68}$. 17 X 1639 Paweł Rożewski, mieszczanin tarnowski, legował na rzecz bractwa $800 \mathrm{f1}$. pol. ${ }^{69}$. Inne wzmianki: $1603-1688,1680,1702^{70}$.

53 Zob. przyp. 46-49. - Wiz. 1597-1725.

54 AOffic. Vol. 35 (1514-1516) S. 271.

55 Zob. przyp. 46.

56 Wiz. 1664 s. 561 (reg.).

57 Muzeum Miejskie poz. 174 (dokum. perg., $20 \times 45 \mathrm{~cm}$ ).

58 F. H e r z $1 \mathrm{~g}$, Jw. S. $44 \mathrm{n}$, 66.

58 ASang. II nr $87-88$ s. 106--107 (1406), nr 104 s. 123 n. (1415). - Por. ks. J. A I b e r s k i: Sredniowleczne bractwo Literackıe NMP w Piĺnie na tle bractw literackıch w Polsce. Tarnów 1961 (maszynopıs) s. 37.

60 Por. F. H e r z 1 g: Katedra s. 44.

61 Conscriptio nr 17 (1517 - reg.), 37 (1540 - reg.).

62 AEp. Vol. $56(1650-1651)$ s. 738. - Por. F. H e r z 1 g, Jw. s. 45.

63 Por. F. He rzig, jw. s. 45 (1685).

64 Tamze S. 46.

65 AEp. Vo1. 58 (1653-1655) s. 484-489. - Por. F. Herzig, jw. S. 46.

66 AEp. Vol. 58 (1653-1655) S. 479-484. - F. He rzlg: Katedra s. $58 \mathrm{n}$.

67 AAdm. Vol. 15 (1657-1658) S. 429-432 (dokum. z 1657). - Acta Officialatus Tarnoviensis 1655-1695 s. 17 (dokum. z 15 XI 1657). - AEp. Vol. 61 (1660-1661) s. 463. - F. H e r zi g, jw. s. 59 (1741).

68 ApBern. Sygn. XIV-a-2: Archivium Conventus Tarnoviensis 1656-1770 s. 65-69. - 
I $G_{6}$. Tarnów. Bractwo św. Franciszka przy klasztornym kościele NMP Śnieżnej zostało założone w r. 1598, za zgodą kard. Jerzego Radziwiłła". Spisy członków bractwa zachowały się $z$ lat $1603-1688$ i $1688-1719^{72}$. $17 \mathrm{X} \cdot 1639$ i 26 VI 1641 bractwo otrzymało pewne legaty ${ }^{73}$. Inne wzmianki: $1680,1742^{74}$.

$\mathrm{I} \mathrm{G}_{7}$. Tarnów. Bractwo św. Antoniego Padewskiego przy kościele klaszŁornym NMP Śnieżnej zaprowadzono I IX $1695^{75}$. Inne wzmianki: $1702^{76}$.

$I_{\text {I }}$. Tarnów. Bractwo Niepokalanego Poczęcia NMP przy klasztornym kościele NMP Śnieżnej erygowano, za zgodą sufr. krak. Michała Szembeka 5 II $1718^{77}$. Bractwo otrzymało bogate zapisy w latach 1718 (3000 fl. pol.), 1729 (3000 fl. pol.), 1738 (2000 fl. pol.), 1739 (1000 fl. pol.), 1740 (1100 fl. pol.) i 1741 (300 fl. pol. $)^{78}$. Spisy czlonków bractwa zachowały się z lat 1718$1898^{29}$.

I $\mathrm{G}_{9}$. Tarnów. Bractwo Rycerskie w celu ,walki z Niemcami i w obronie Węgier" założył 8 IV 1528 Jan Zapolya, król wegierski ${ }^{80}$. Innych wzmianek brak.

I $G_{10}$. Tarnów. Bractwo Strzeleckie istniało przynajmniej od r. $1555^{81}$.

I $\mathrm{G}_{11}$. Tarnów. Trzeci zakon św. Franciszka istniał w latach 1541-1761; przeciętnie przyjmowano do tercjarzy 1-2 osób rocznie ${ }^{32}$.

I $\mathrm{G}_{12}$. Tarnów. Cech krawców otrzymał pierwsze przywileje w r. $1445{ }^{83}$. Inne wzmianki: $1647,1742,1764^{84}$.

$\mathrm{I} \mathrm{G}_{13}$. Tarnów. Cech sukienniczy otrzymał statuty w latach $1444-1479{ }^{85}$.

Officialía Kazımierski informują (pod r. 1591) o ,Fraternitas S. Annae ad ecclesiam Bernardinorum".

69 APBern. Sygn. XIV-a-2: Archivium s. $65 \mathrm{nn}$.

70 Tamze. Sygn. XIV-a-6: Regest wpısowania braciey I sióstr do Bractwa Anny Swiętej Samotrzeciey (1603-1688), - AAdm. Vol. 16 s. 28-29 (1680). - A.PBern. Sygn. XIV-h-1. Akta rózne (1499-1938) k. 171 (Wiz. 1702).

71 APBern. Sygn. XIV-a-2: Archivium s. 65-69.

72 Tamze. Sygn. XIV-e-6. Regest wpisowania (1603-1688). - Sygn. XIV-c-7. Ksiega bractwa św. Franciszka (1688-1719). - Por. O. H. E. W y c za w s 1 OFM. Katalog. T. 5: 1962 s. 109.

73 Tamze. Sygn. XIV-a-1. Archivium 1656 s. $65-69$.

74 AAdm. Vol. 16 (1680) s. $28 \mathrm{n}$. - Oplsanie posiadtoścl s. 36 (1742).

75 APBern. Sygn. XIV-a-1: Archivium s. 31.

76 Tamze. Sygnn. XIV-h-1: Akta rózne (1499-1938) k. 171 (Wiz. 1702).

77 Tamze. Sygn. XIV-a-1. Archivium s. 73. - Sygn. XIV-e-2: Liber continens in se susceptos in confraternitatem s. 15 (dokum. bpa Szembeka).

78 Tamze. Sygn. XIV-a-1. Archivium 1656 k. 6' (1718), s. $73-81$ (1729), 81-83 (1733), 83-84 (1739), 85-86 (1740), 86-87 (1741). Sygn. XIV-e-2: Liber continens in se susceptos s. $73-81$ (1729).

79 Tamże. Sygn. XIV-e-2: Liber 1718-1898. - Por. O. H. E. W y c zaw s k : Katalog. T. 5. 1962 S. 108.

80 w. P oc i e ch a, Królowa Bona (1494-1557). T. 4. Poznań 1958 s. 26 n.; Dodatki, nr 2 S. 293-294 (dokument).

81 J. Lenie k, jw. S. 34 .

82 APBern. Sygn. XIV-a-1: Archivium Conventus Tarnoviensis s. 293 nn. - Sygn. XIV-a-2: Archivium 1656-1770 s. 407-428.

83 Muzeum miasta Tarnowa: Inwentarz nr 249 - sygn. 88-L-213 (or. perg. $26 \times 54 \mathrm{~cm}$ ); nr $248-$ sygn. $87-\mathrm{L}-212-\mathrm{Nr}$ VI (or. perg. $65 \times 65 \mathrm{~cm}$ ).

84 Opisanie osiadłości 1742 s. 8. - Acta Officialatus Tarnoviensis 1763-1764 (pod data 16 I 1764). - Muzeum, nr 530 - sygn. 12-81 (Kr.-L.221-L.19 (1647).

85 Muzeum miasta Tarnowa: Inwentarz or 256 - sygn. 95 (or. perg., $60 \times 39 \mathrm{~cm}$ ). 
W r. $1633 \mathrm{ks}$. Dominik Ostrogski nadał cechowi nowe prawa ${ }^{\mathrm{s}}$. Inne wzmianki: $1487,1634^{87}$.

$\mathrm{I} \mathrm{G}_{14}$. Tarnów. Cech szewski otrzymał statuty $\mathrm{z}$ rąk rady miasta Tarnowa w r. $1457^{88}$. W r. 1493 Jan Amor Tarnowski nadal cechowi nowy statut $^{89}$. 29 IX 1499 kard. Fryderyk Jagiellończyk, bp krak., obdarował bractwo odpustami ${ }^{90}$. Dalszych przywilejów udzielił cechowi Jan Amor Tarnowski w $r$. $1522^{91}$. Inne wzmianki: $1742,1764^{92}$.

I $\mathrm{G}_{15}$. Tarnów. Cech „Wielki”, obejmujący kołodziejów, powrożników, kuśnierzy, kapeluszników i innych rzemieślników otrzymał w r. 1452 pierwsze prawa ${ }^{93}$. W latach $1456,1479,1523,1604,1726$ cech otrzymal zatwierdzenie statutów i nowe przywileje ${ }^{94}$. Inne wzmianki: $1764^{95}$.

I $G_{16}$. Cech rzeźniczy otrzymał statuty $z$ rąk Jana Amora Tarnowskiego w r. $1494^{96}$. Dalsze przywileje pozyskał on w r. 1527 i $1555^{97}$. Inne wzmianki: $1742,1764^{88}$.

I G $G_{17}$. Tarnów. Cech bednarzy istniał już w r. $1527^{99}$. W latach 1541 i. 1557 cech otrzymał dalsze przywileje ${ }^{100}$.

I $\mathrm{G}_{18}$. Tarnów. Cech stelmachów otrzymał przywileje w r. 1557; prawdopodobnie był połączony $\mathrm{z}$ cechem bednarzy ${ }^{101}$. W r. 1646 rada miasta zezwoliła na utworzenie odrębnego cechu stelmachów, kołodziei i stolarzy ${ }^{102}$. W r. 1649 ks. Władysław Dominik Ostrogski nadał cechowi przywileje ${ }^{103}$. Inne wzmianki: $1742^{104}$.

I $\mathrm{G}_{19}$. Tarnów. Cech kuśnierzy istniał $\mathrm{w}$ r. $1647^{105}$. Inne wzmianki: $1742,1764^{106}$.

86 Państwowe Muzeum Ziemı Tarnowskıej w Tarnowie: Inwentarz nr 195 -- syg!l. 34-L.37 (or. perg. $8 \mathrm{k}, 27 \times 21 \mathrm{~cm}$ ).

87 Testis 1763 S. 5 , ,H" (reg. dokum. z 14 III 1634). - K. Szczeklik: Pilzno i pilznianie. Kraków 1911 s. 194 (dokum. z 28 II 1487). - Por. J. L e n i e k, Jw. s. 34.

88 Państwowe Muzeum Ziemı Tarnowskiej: Inwentarz nr 163 - sygn. 2-L.2 (or. perg., $50 \times 31 \mathrm{~cm})$

88 Tamze: Inwentarz nr 168 - sygn. 8-L.8 (or. perg., $34 \times 64 \mathrm{~cm}$ ).

80 Tamze: Inwentarz nr 171 - sygn. 10-L.10 (or, perg.). - Por. F. H e r z 1 g: Katedra s. $4 \overline{5}$.

91 Tamze: Inwentarz nr 175 - sygn, 14-L.14 (or. perg., $43 \times 51 \mathrm{~cm}$ ).

92 Opısanie osıadłoścı 1742 s. 8. - Acta Officıalatus Tarnoviensis 1763-1764 (pod datą 16 I 1764).

93 Muzeum miasta Tarnowa: Inwentarz nr 221 - sygn. 59-L.1-L.XI-Nr VIII (or. perg., $43 \times 21 \mathrm{~cm})$.

94 Tamze: Inwentarz nr 221 - sygn. 60-L.2- V-Nr XIX (1456). Inwetnarz $\mathrm{nr} 222$ - sygu. 61-L.3-Nr XVI-L.VII (1479). - Inwentarz nr 223 - sygn. 62-L.4-Nr XX-XXXIII (1523). Inwentarz nr 227 - sygn. 66-L.10-L.XIV-Nr VI (1604). - Inwentarz nr 239 - sygn. 404-526-78-L.25. L.VI-Nr XVII (1726).

95 Acta Officialatus Tarnoviensis 1763-1764 (pod datą 16 I 1764). - Por. J. I en i k Tarnów s. 34 .

90 Muzeum miasta Tarnowa: Inwentarz nr 219 - sygn. 58 (or. perg., $47 \times 49 \mathrm{~cm}$ ).

97 Tamze: Inwentarz nr 515 - sygn. 7-L. 27 (1527). - Inwentarz nr 519 - sygn. 1-L.65 (1555).

98 Zob. przyp. 92.

99 Muzeum miasta Tarnowa: Inwentarz nr 510 - sygn. 2-L.6-105/CW. - Inw. 169-L.XIII.t.

100 Tamze: Inwentarz nr 225 - sygn. $64-\mathrm{L} .7-\mathrm{L} . \mathrm{XV}-\mathrm{Nr}$ XII (or, perg., $31 \times 62 \mathrm{~cm}$ ). Inwentarz nr 510 - sygn. 2-L.6-105/CW. - Inw. 169-L.XIII (1541).

101 Tamże.

102 Tamże: Inwentarz nr 199 - sygn. 38-L.41 (or. perg., $48 \times 29 \mathrm{~cm}$ ).

103 Tamże: Inwetnarz nr 533 - sygn. 15-102/CW - L.21-L.VIII (org. perg.).

104 Opisanie 1742 s. 8.

1.05 Muzeum miasta Tarnowa: Inwentarz nr 530 - sygn. 12-81/Kr. -L.221-L.19.

106 Zob. przyp. 92. 
I $\mathrm{G}_{20}$. Tarnów. Cech garncarzy otrzymał przywileje w r. 1670, statuty zaś $1680^{107}$.

$\mathrm{I}_{21}$. Tarnów. Cech piekarzy otrzymał przywileje w r. $1670^{108}$. Inne wzmianki: $1742^{109}$.

$\mathrm{I} \mathrm{G}_{22}$. Tarnów. Cech metalowy otrzymał statuty w r. $1675^{110}$. W r. 1754 król August II zatwierdził przywileje cechu ${ }^{\mathbf{1 1 1}}$.

I $G_{23}$. Tarnów. Cech piwowarski istniał w r. $1742^{112}$.

I $\mathrm{G}_{24}$. Tarnów. Cech kołodziejski istniał w $r$. $1742^{113}$.

I $\mathrm{G}_{25}$. Tarnów. Cech kowalski jstniał w r. $1742^{114}$; należeli doń: „kowale, kotlarze, ślusarze, miecznicy, złotnicy a później także zegarmistrze" ${ }^{115}$.

I $\mathrm{G}_{26}$. Tarnów. Cech tkacki istniał w r. $1742^{116}$.

I $\mathrm{G}_{28}$. Tarnów. Cech winiarzy istniał w r. $1742^{118}$.

I $\mathrm{G}_{29}$. Tarnów. Cech stolarski istniał w r. $1752^{119}$.

I $G_{30}$. Tarnów Cech czapników istniał w XVII w. (przed r. 1670) ${ }^{120}$.

I $\mathrm{H}_{1}$. Tarnów. Szkoła parafialna, według F. Herziga, powstała jeszcze przed wyniesieniem kościoła Narodzenia NMP do godności kolegiaty, a więc przed r. $1400^{121}$. Według A. Karbowiaka „miasto musiało mieć szkołę parafialną już w XIV w." ${ }^{122}$. Najdawniejsza wzmianka źródłowa o szkole datuje się na rok 1513 i $1527^{123}$ Pierwotne uposażenie szkoly miały stanowić odsetki roczne w wysokości $85 \mathrm{zł} \mathrm{pol.}{ }^{124}$. 16 IV 1555 rada miasta Tarnowa powiększyła uposażenie kierownika szkoły o 4 grzywny rocznie ${ }^{\mathbf{1 2 5}}$. Na prośbę ks. Marcina Łyczki, prepozyta tarnowskiego, hetman Jan Tarnowski, kasztelan krakowski, wystawił 18 VI 1559 dokument fundacyjny szkoły, przydzielając jej $\mathrm{m}$. in. dziesięcinę snopową $z$ folwarków w Nagoszynie i Borowcu ${ }^{128}$. W miejsce „lichego budynku" ks. M. Eyczko wybudował „murowany dom piętrowy na pomieszczenie szkoły" ${ }^{127}$. W zapisie testamentalnym ks. M. Eyczko, prepozyt tarnowski, legował (8 V 1578) 1000 zł pol. na kształcenie 3 chłopców na Uniwersytecie Krakowskim, aby po uzyskaniu stopnia bakałarza nauczali

107 Muzeum masta Tarnowa: Inwentarz nr 243 - sygn. 83-L.200-305 (or. perg., $65 \times 85 \mathrm{~cm}$

$z$ r. 1670). - Inwentarz nr 540 (z r. 1675).

108 Tamze: Inwentarz nr 244 - sygn. 83-L.200-305 (or. perg., $65 \times 85 \mathrm{~cm}$ ).

109 Zob. przyp. 104.

110 Muzeum miasta Tarnowa. Inwentarz nr 242 - sygn. 81-3-L.174-294 (or. perg., $53 \times 80 \mathrm{~cm}$ ).

111 Tamże: Inwentarz nr 242 - sygn. 79-1-L.172-313 (or. perg., $38 \times 29$ cm).

112 Opisanie 1742 s. 8.

113 Tamźe.

114 Tamze.

115 J. L en i e k: Tarnów za czasów Leliwitów s. 34.

116 Opisanie 1742 s. 8 . - Por. $J$. L e n i e k, jw. s. 34.

118 Opisanie 1742 s. 8.

110 Muzeum miasta Tarnowa: Inwentarz nr 566 - sygn. 48-98/Stol.-L.2 (odpis doklum. z 1752 sporządzony $w$ r. 1801).

120 F. Herzig: Katedra s. 37. - Tenże: Tarnów s. 121.

121 F. Herzig: Katedra s. 83. - Tenź e: Tarnów s. 144.

122 A. Kar b owiak: Dzieje wychowania i szkół w Polsce. Cz. 2: 1364-1432. Petersburg 1903 S. 42.

123 LR $1513 \mathrm{k} .22$ - rector scole; LR $1527 \mathrm{k} .45$ - cantor scole.

124 F. Herzig: Tarnów S. 145.

125 Tamże. - T e n z e: Katedra s. 84.

126 Muzeum. miasta Tarnowa: Inwentarz 183 - sygn. 22-L.23 (đok. perg., $26 \times 37 \mathrm{~cm}$ ). -

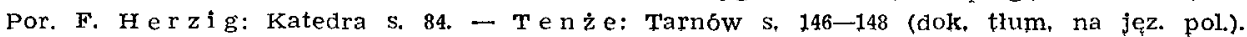
127 F. H e r z $1 \mathrm{~g}$ : Katedra s. 84. 
w miejscowej szkole. 3 III 1581 zapis potwierdził król Stefan Batory ${ }^{128}$. 14 VIII 1591 kan. tarn. Erazm Marcinkowski przekazał w testamencie szkole własną bibliotekę ${ }^{120}$. W r. 1597 budynek szkolny, stojący kolo kościoła kolegiackiego, „był murowany, posiadał 3 izby, jedną - wielką dla nauczania młodzieży, drugą - mniejszą, z komorą na mieszkanie kierownika, trzecią, również z komorą, dla kantora; nadto komory dla chłopców". Wizytator w r. 1597 informuje obszernie o uposażeniu szkoły ${ }^{130}$. Dalsze poważne legaty na rzecz szkoły tarnowskiej poczynił 6 X 1629 i 3 II 1639 ks. Andrzej ze Szczekarzewic Tarło, prepozyt tarnowski ( $\dagger 17$ VIII 1692), przeznaczając kantorowi i uczniom $30 \mathrm{zl}$ pol. oraz dla bakałarza 50 zł pol.; w zapisie drugim przeznaczył on ,kantorowi i jego pomocnikom 50 zł pol." ${ }^{131}$. 16 III 1650 bp krak. Piotr Gembicki uregulował kwestie sporne między kapitułą kolegiacką a szkoła tarnowską, zaś 23 III 1650 „jus providendi et praesentandi" bakałarza szkoły przysądził prepozytowi kolegiaty ${ }^{132}$. Do r. 1663 bezpośredni zarząd nad szkołą spoczywał w rękach prałata kantora ${ }^{133}$. 11 III 1647 bp krak. Piotr Gembicki erygował przy kolegiacie prałature scholasterię ${ }^{\mathbf{1 3 4}}$, której w r. 1663 oficjał tarnowski podporzadlowal sprawy szkolne ${ }^{135}$. 10 I 1708 ks. Piotr Stanisław Orłowski, prepozyt-infułat tarnowski, zapisał w testamencie 2000 zł pol. dla uczniów szkoły ${ }^{136}$. W r. 1725 ,szkoła murowana potrzebowała naprawy". Bp krak. Konstanty Felicjan Szaniawski polecił „scholastykowi, by z pomocą mieszczan i kapituły kolegiackiej szkołę tarnowska, mocno zdewastowana, odnowil w ciagu jednego roku"; nadto nakazal on temuz prałatowi prezentowanie ,zawsze odpowiedniego kierownika szkoły" i rewindykacje legatów, zapisanych na rzecz szkoły ${ }^{132}$.

$\mathrm{I} \mathrm{H}_{2}$. Tarnów. Kolonię akademicką przy kolegiacie tarnowskiej ufundował ks. Wojciech Kaszewicz, scholastyk tarnowski († 9 III 1753), przeznaczając $\mathrm{w}$ zapisie testamentalnym na jej utrzymanie (21 XII 1752--2 III 1753) łącznie 25000 zł pol. Z sumy tej przydzielił dla każdorazowego rektora kolonii akademickiej i profesora retoryki $600 \mathrm{zl}$ pol, dla profesora poetyki -300 , dla profesora gramatyki - 60; na fundacje prebendy kanonickiej bł. Jana Kantego dla rektora tejże kolonii - 280 zł pol. rocznego dochodu (od sumy 4000 zł pol.); wreszcie dla uczącej się młodzieży 1200 zł pol. i folwarczek w Tarnowie. Na skutek szeregu trudności dopiero 17 III 1760 bp krak. Ignacy Kajetan Sołtyk zatwierdził, z pewnymi zmianami, fundacje oraz utworzył kolonię akademicką i kanonię bł. Jana Kantego ${ }^{138}$. 19 X 1767 oficjał kra-

\footnotetext{
128 F. Herzig: Tarnów s. 149-153. - T e n z e: Katedra s. 113.

129 Officialia Kazımierskı s. 55.

130 Por. Kot: Szkolnictwo s. $175 \mathrm{n}$.

131 F H erzig: Katedra s. 113 n. - Tenze: Tarnów s. $155 \mathrm{n}$.

132 AEp. Vol. 58 (1653-1655) s. $52 \mathrm{n}, 66 \mathrm{n}$.

133 Officialia Kazimierski s. 24 (dolrum. z 23 XII 1585).
}

194 AEp. Vol. 55 (1647-1649) s. 88-92. - Conscruptio nr 102 (reg.). - Archiwum miasta Tarnowa: Inwentarz dokumentów papierowych s. 23. - Por. F. H e r z i g: Katedra s. 57 n. O. H. E. W y z a w s l 1 OFM. Biskup Piotr Gembick1 1587-1657. Kraków 1957 s. 219.

135 F. Herzig: Tarnów s. 156. - Tenze: Katedra s. 58.

136 F. H e r zig: Katedra s. $156 \mathrm{n}$.

137 Akta wizytacji kolegiaty 1725 s. 13.

138 AEp. Vol. 98 (1760) s. 241 (calość dokumentacji przy końcu woluminu). - Ks. Izydora Chróscińskiego Kronika z lat 1784-1794. - Bibliot. Ossol. Sygn. 9633/II: Erectio Coloniae Academicae Tarnoviensıs. - Gymnasıum Tarnovlense erigitur anno 1760 . Ed. J. K oz 1 c k i. Cracoviae 1898, -- Por, F. HerzIg: Iratedra s. 93 nn. - T c n z e: Tarnów s. 157 nn, - - 
kowski zatwierdził testamentalny zapis 1600 zł pol. na rzecz kolonii akademickiej ${ }^{139}$. Przedsięwzięta na kapitule kolegiackiej 9 IX 1773 i 11 IX 1780 reforma kolonii nie doszła do skutku; w r. 1784 lsolonia akademicka została przekształcona na 5 klasowe gimnazjum ${ }^{140}$. W r. 1766 kolonia liczyła 212 uczniów, a w 1784 r. $-59^{141}$. (Por. I $\mathrm{L}_{1-11}$ ).

I $\mathrm{H}_{3}$. Tarnów. W r. 1608 kapituła prowincjalna bernardynów postanowiła, ze w tarnowskim klasztorze będą zorganizowane studia ,humanıora" dla kandydatów do kapłaństwa ${ }^{142}$. Studium Teologiczne OO. Bernardynów przy klasztorze M. B. Śnieżnej istniało w r. 1655; w tymże roku obowiązki profesorów pełniło 3 ojców lektorów, a studentów było $10^{143}$. W r. 1725 istniało tu tylko studium filozoficzne

I J. Tarnów. Wiz. 1664 informuje, że z okazji uroczystości Trójcy św. ,jest duży napływ ludzi - do kościoła Trójcy św. - na Terlikówce" z odległych okolic, którzy zgodnie ze starcdawnym zwyczajem zwykli przychodzić „cum oblationibus et votzs".

I L L $_{1}$ Tarnów. Kolegiatę p. w. Narodzenia NMP a przy niej kapitułę ufundował Jan Tarnowski, wojew. sandomierski; erygował ją 17 IV 1400 bp krak. Piotr Wysz ${ }^{144}$. Erekcję kolegiaty potwierdził w r. 1418 pap. Marcin $\mathrm{V}^{\mathbf{1 4 5}}$. Kolegiatę zniósł 13 III 1786 pap. Pius VI bullą In suprema beati Petri cathedra ${ }^{146}$.

Prała tury kapituly:

1. Prepozytura została ufundowana przez Jana Tarnowskiego i uposażona na dochodach dawnego probostwa parafii Narodzenia NMP w Tarnowie; erygował ją 17 IV 1400 bp krak. Piotr Wysz ${ }^{147}$. Jurysdykcji ,ad instar archi diaconatus" prepozyta tarnowskiego podlegało od $1416 \mathrm{r}$. w dekanacie tarnowskim 7 parafii, od 1542 - 10, od 1616 - 17, od $1686-18$ i od $1711-21$ parafii. 7 XI 1689 pap. Aleksander VIII nadał prepozytom tarnowskim tytuł praepositus-infulatus i przywilej używania pontyfikaliów w obrębie tamtejszego oficjałatu ${ }^{148}$. Inne wzmianki: $1470,1513,1527,1529,1539,1561,1577$, 1597, 1725. Por. F. He r zig. Katedra s. 14 nn.

Patronat: szlachecki ${ }^{149}$.

2. Kustodia została ufundowana przez Jana Tarnowskiego i uposażona dochodami kaplicy p. w. Bożego Ciała, zwanej także altarią św. Krzyża; erygowal ją 17 IV 1400 bp krak. Piotr Wysz ${ }^{150}$.

Inne wzmianki: 1470-1725. (Por. prepozytura i zob. $\mathrm{I}_{2}$ ).

A. Przyboś: Akademia Krakowska w drugiej polowie w. Xvit. W' Dzzeje Unzwersytesu Jagiellonskiego $w$ latach 1364-1764. (Red. K. Lepszy). T. 1. Kraków 1964 s. 347.

139 AOffic. Vol. 199 (1767) k. 187-188. - Por. F. Herzig: Tarnów s. 164.

140 F. Herzıg: Katedra s. 92. - Tenze: Tarnów s. 170. - 2. Fu ta: Gimnazjum tarnowskie w latach 1784-1794. Rocz. nauk.-dydakt. WSP $w$ Krakowie. Prace historyczne. R. 2: 1965 s. $67-83$.

141 F H e r z 1 g: Tarnów s. 164, 170.

142 Ks. K. K a n t a : Bernardynı polscy, T. 2 s. 297.

143 APBern. Sygn. XIV-a-1. Archivium Conventus Tarnoviensis 1656-1770 s. 355.

144 ZOb. przyp. 5.

145 Zob. przyp. 6.

146 K u m or' Dzieje s. 114.

147 Zob. przyp. 5. - LBD, I s. 606-609. - Por. F. H e r z g: Katedra S. 14-19.

148 Conscriptio nr 51 (reg.). - Por. F. H e rzig, jw. s. 15.

149 ASang. II nr 80 s. 94-97. - LBD, I s. 605.

150 Por. przyp. 149. - LBD, I s. 609-610. - Por. F Herzig, jw. s. $19 \mathrm{n}$. 
Patronat: szlachecki ${ }^{151}$.

3. Kantoria czyli prymicerat została ufundowana przez Jana Tarnowskiego i uposażona beneficjum dawnej parafii św. Marcina „sub castro Tarnoviensi"; erygował ja 17 IV 1400 bp krak. Piotr Wysz ${ }^{152}$. Inne wzmianki: 1470-1725. (Por. prepozytura).

Patronat: szlachecki ${ }^{153}$.

4. Scholasteria została ufundowana 25 II 1647 przez Baltazara i Barbare Bujakiewiczów, mieszczan tarnowskich, którzy na ten cel zapisali $3000 \mathrm{zl}$ pol.; erygował ją 11 III 1647 bp krak. Piotr Gembicki ${ }^{154}$. Od r. 1663 scholastykowi powierzono sprawy szkoły tarnowskiej (por. I $\mathrm{H}_{1}$ ). Inne wzmianki: 1725$1.785^{155}$.

Patronat: fundatorowie, a po ich śmierci rada miasta Tarnowa i Wojnicza ${ }^{156}$.

5. Dziekania została uposażona 3 IV 1659 przez ks. Jacka Sliwskiego, dziekana i probcszcza w Jaśle, który na ten cel zapisał 3000 zl pol. 19 IX 1660 kapituła wyraziła zgodę na erekcję prałatury-dziekanii. Erygował ją 15 XI 1660 bp krak. Andrzej Trzebicki ${ }^{157}$. Dalsze poważniejsze legaty na rzecz prałatury poczynili: ks. Jacek Śliwski - $3000 \mathrm{zl}$ pol. (1683), ks. Krzysztof Rogoziński 2000 zl pol. (1705) i ks. Aleksander Nadolski - 2048 zł pol. (1731) ${ }^{168}$. Inne wzmianki: $1725-1785^{159}$.

Patronat: Kapituła kolegiacka w Tarnowie ${ }^{\mathbf{1 0 0}}$.

6. Kancelaria została ufundowana w r. 1682 przez ks. Pawła Konstantego i jego brata Piotra Kuszewskiego; zgodę na utworzenie nowej prałatury kapituła wyraziła 1 IX 1681. Erygował ją 10 VII 1682 bp krak. Jan Małachowski ${ }^{161}$. Inne wzmianki $1725-1785^{162}$.

Patronat: szlachecki; po wymarciu rodziny Kuszewskich — kapituła kolegiacka i rada miasta Tarnowa ${ }^{163}$.

7. Archidiakcnia została ufundowana 9 IX 1694 przez ks. Grzegorza Nadkańskiego, kanonika tarnowskiego, który na ten cel legował łącznie 8000 zł pol. Erekcji prałatury dokonał $16 \mathrm{~V} 1695$ bp krak. Jan Małachowski.

151 Zob. przyp. 149.

152 Zob. przyp. 149. - LBD, I s. $611-612$. - Por. F. Herzig, Jw. s. 20 n.

153 Zob. przyp. 149.

154 AEp. Vol. 55 (1647-1649) k. 88-92. - Conscriptio nr 102 (reg.). - F. H e r zi g: Katedra s. 56-58. - Tenze: Tarnów s. 112 n. - O. H. E. W y c za w s ki: Biskup Piotr Gembicki s. 219.

155 Por. F. H e r zi g, jw. s. $56 \mathrm{nn}$.

156 Zob. przyp. 154.

157 AOffic. Vol. $139(1659-1660)$ s. 1952-1964. - Conscriptio nr 15 (reg.). - Por. F. H e rzig: Katedra s. 60-62. - T e nże: Tarnów s. 116. — AEp. (Vol. 56, 1650-1651 k. 638-640) informuja, że stało się to $24 \mathrm{~V}$ 1651, za bpa P. Gembickiego.

158 F. H e r z i g: Katedra s. 61.

150 Tamże s. $61 \mathrm{n}$.

160 Zob. przyp. 157.

161 AAdm. Vol. 17 (1702-1703) s. 1494-1507. - Conscriptio nr 73 (reg.). - Por. F. He rz i g: Katedra s. 63-65. - AEp. (Vol. 61. 1661-1666 k. 351-352 i ADT (Fasc. Tarnów, kopia dolkum. z $7 \mathrm{~V}$ 1663) podają, jakoby prałaturę te udotowal Aleksander Gratus Tarnowskj, kant. kijowski, a erygowal ją $7 \mathrm{~V} 1663$ bp krak. A. Trzebicki. Dane te jeđnakże odnoszą się do kanonii fundi Ksiąznice. - Por. F. He rzig: Katedra s. 62 n. - Tenże: Tarnów s. 124.

162 Por. F. H e Izig: Katedra s. $64 \mathrm{n}$,

163 Tamże, 
Fundator zawarowal godność archidiakona dla osób posiadających stopień doktora ${ }^{164}$. Inne wzmianki: $1725-1785^{165}$.

Patronat: rada miasta $w$ Miechowie podawała trzech kandydatów, kapituła tarnowska wybrała jednego $\mathrm{z}$ nich, a burmistrz i notariusz miasta Miechowa prezentowali go biskupowi do instytucji kanonicznej ${ }^{166}$.

Kanonie kapituły:

1. Kanonia fundi S. Mariae de castro Tarnoviensi została uposażona przez Jana Tarnowskiego, wojew. sandomierskiego, dochodami prebendy kaplicy Najśw. Maryi Panny na zamku tarnowskim (por. Tarnów — parafia NMP „na zamku tarnowskim"); erygował ja 17 IV 1400 bp krak. Piotr Wysz ${ }^{107}$. Inne wzmianki $1470-1725-1785$. (Zob. prepozytura) ${ }^{168}$.

Patronat: szlachecki ${ }^{169}$.

2. Kanonia p. w. Św. Bartłomieja została ufundowana na dochodach altarii św. Bartłomieja; erygował ją 17 IV 1400 bp krak. Piotr Wysz ${ }^{170}$. Inne wzmianki: $1470-1725-1785^{171}$. (Por. I $\mathrm{M}_{1}$ ).

Patronat: szlachecki ${ }^{172}$.

3. Kanonia fundi Łukowa p. w. Rozesłania Apostołów (na pamiątkę zwycięstwa grunwaldzkiego) została ufundowana 2 IV 1415 przez Jana Tarnowskiego i Spytka Jarosławskiego w nowozbudowanej kaplicy i uposażona wsią Łukowa. Kanonię erygowal 14 IV 1417 bp krak. Wojciech Jastrzębiec ${ }^{173}$. Inne wzmianki: $1470-1725-1785$. (Por. prepozytura) ${ }^{174}$.

Patronat: szlachecki ${ }^{175}$.

4. Kanonia fundi Wierzchosławice p. w. św. Barbary została udotowana przez Jana Amora Tarnowskiego, kaszt. krak., 22 I 1494 przez połączenie beneficjum parafii św. Wojciecha w Wierzchosławicach $z$ altarią p. w. św. Barbary p. i. m. w kolegiacie tarnowskiej ${ }^{176}$. Nowy przywilej fundacyjny kanonii Wierzchosławice, podobny w treści do dokumentu z 22 I 1494, wystawił Jan Amor Tarnowski 28 IV $1498^{177}$. Erygowal ją 19 XII 1498 kard. Fryderyk Jagiellończyk, bp krak. ${ }^{178}$. Inne wzmianki: 1513-1725-1785. (Por. prepozytura; ${ }^{179}$ zob. I $\mathrm{M}_{3}$ ).

164 AEp. Vol. 72 (1694-1696) k. 137-144. - Descriptio nr 16. - Por. F Herz1g: Katedra s. 69. - Te n z e: Tarnów s. 125.

165 F, H e r zig: Katedra s. 70.

160 Zob. przyp. 164.

167 ASang. II $\mathrm{nr} 80$ s. 94-97. - LBD, I s. 612-613. - Por. F. H e r z i g: ILatedra s. 22. -

Długosz daje jej błędnie drugı tytuł: „Rozesłanie Apostołów".

108 Por. F. Herzig: Katedra s. 22.

1 B9 ZOD. przyp. 149.

170 Zob. przyp. 167. - LBD, I s. 614. - Por. F. Herzig: Katedra s. 22.

171 Por. F. Herzig: Katedra s. 22 n.

172 Zob. przyp. 170. - ASang. II $\mathrm{nr} 111$ s. 133 (21 V 1418).

173 A.Sang. II $\mathrm{nr} 103$ s. $121-123$ (1415), $\mathrm{nr} 107$ s. $128-129$ (1417). — LBD, I s. 614-615. -

Por. F. Herzig: Katedra s. 23-24.

174 Por. F. Herzig: Katedra s. $24 \mathrm{n}$.

175 Zob. przyp. 173.

170 ASang. II $\mathrm{nr} 201$ s. 250-251. - Por. F. He rzig: Katedra s. $40 \mathrm{n}$. - K u mor: Zanik I afiliacja s. 110 .

177 ASang. II nr 211 s. 268-273. - Por. Herzig: Katedra s. 41. - Ku mor: Zanik 1 afiliacja s. 110.

178 ASang. II nr 212 s. 274-277. - Por. F. IH e r zig: Katedra s. 43. - K u mor Zanik i afiliacja s. 110. - Ks. H. R y b u s: Królewicz kardynał Fryderyk Jagiellończyk jako biskup krakowski 1 arcybiskup gnieźnieńsk1. Warszawa 1935 s. 92. (Studia Historico-Ecclesiastica. [T.] 2). 
Patronat: szlachecki ${ }^{180}$.

5. Kanonia p.w. Wniebowzięcia NMP „na Burku” została ufundowana przez Prokopa Rokosza, właściciela wsi Buchcice, Annę Kołaczkowską z Kołaczlkowic i Pawła Ciombera, mieszczanina tarnowskiego, którzy 27 VIII 1621 przeznaczyli na ten cel dom, jeden lan ziemi i rolę „Ruda" w Tarnowie. Kanonię erygował 15 XII, za zgodą ks. Janusza Ostrogskiego, bp krak. Marcin Szyszkowski ${ }^{181}$. 25 VIII 1625 Tomasz i Małgorzata Schabowie z Tarnowa zapisali na rzecz prebendy kanonickiej rolę zwaną "Wąchalińska" ${ }^{182}$. Wzmianki: $1725-1785^{183}$.

Patronat: szlachecki ${ }^{\mathbf{1 8 4}}$.

6. Kanonia kaznodziejska I ministerii p. w. Mikołaja została utworzona przez kapitułę kolegiacką $30 \mathrm{~V} 1622$ i udotowana beneficjum kaznodziei kolegiackiego (legaty z r. 1458, 1530, 1535, 1546 i 1559) ${ }^{185}$. Erygował ją 17 VI 1622 bp krak. Marcin Szyszkowski, co potwierdził jeszcze raz 21 V 1644 bp krak. Piotr Gembicki ${ }^{188}$. Dalsze poważniejsze zapisy na rzecz kanonii kaznodziejskiej nastąpiły $w$ latach 1624,1625 i $1677^{187}$. Inne wzmianki: 1725-1785 ${ }^{188}$. (Por. I $\mathrm{M}_{8}$ ).

Patronat: kapituła kolegiaty tarnowskiej ${ }^{189}$.

7. Kanonię fundi Książnice p. w. św. Karola Boromeusza uposażył 15 III 1663 Aleksander Gratus Tarnowski, kantor kijowski, legując na ten cel 3000 zł pol.; erygował ją $7 \mathrm{~V} 1663$ bp krak. Andrzej Trzebicki ${ }^{190}$. 13 XII 1703 Jan Gratus Tarnowski wydal dokument wcielający beneficjum parafii Książnice do uposażenia kanonii; nie wiadomo jednakże, czy inkorporacja doszła do skutku ${ }^{191}$. Inne wzmianki: $1725-1785^{102}$.

Patronat szlachecki ${ }^{193}$.

8. Kanonia penitencjaria p. w. św. Anny została ufundowana przez ks. Macieja Kmitę, altarzystę tyt. św. Anny w kolegiacie tarnowskiej; 10 IX 1674 zrzekł się on na rzecz nowej kanonii dochodów $z$ altarii św. Anny II ministerii, a nadto legował na ten cel $2000 \mathrm{zl}$ pol. ${ }^{194}$. 27 III 1677 krewni fundatorki rzeczonej altarii wnieśli odwołanie do oficjała krakowskiego

179 Por. F. Herzig: Katedra s. $43 \mathrm{nn}$

180 Zob. przyp. 176-178.

181 Conscriptio nr 99 (reg.). - Por. F. Herzlg: Katedra s. 51. - Tenze: Tarnów S. 105 .

182 F. H e r z 1 g: Katedra s. 51.

183 Tamże s. 52.

184 Tamze.

185 AEp. Vol. 12 k. 17 (dokum. z 26 IV 1530), vol. 13 k. 516 (dolsum. z 22 X 1535), vol. 14 (1524-1536) k. 174. - Conscriptio nr 34 (1535), nr 33 (1546). — F. He r z g: Katedra s. 52 nn. $(1458,1559)$.

186 Conscriptio nr 32 (1644). - F. He r z 1 g: Katedra s. 54. - T e n z e: Tarnów s. 105.

187 F. H e r z $1 \mathrm{~g}$ : Katedra s. $54 \mathrm{n}$.

188 Tamze s. $55 \mathrm{n}$.

189 Tamze s. 55.

190 AEp. Vol. 61 (1661-1666) k. 351-352'. - ADT: Fasc. Tarnów (kopia z XVIII w.). Błędne i niejasne informacje na temat erekcji tej kanonii podaje F. Herzig (Katedra s. 62; Tarnów s. 117).

101 F. H erzig: Katedra s. 63.

182 Tamze.

193 zob. przyp. 190.

194 AOffic. Vol. 156 (1683-1685) s. 1153-1164. Por. F. H e r z $\ddagger$ g: Katedra s. 65. - T e n ż; Tarnów s. 124 . 
przeciwko wcieleniu altarii do prebendy kanonickiej ${ }^{195}$. Kanonię erygowal 19 II 1685 bp sufr. krak. M. Oborski ${ }^{196}$. Inne wzmianki: 1725-1785 ${ }^{107}$. (Por. I $\mathrm{M}_{10}$ ).

Patronat: rada miejska Tarnowa ${ }^{198}$.

9. Kảnonia fundi Górecki została ufundowana 15 II 1697 przez ks. Kazimierza Góreckiego, kan. tarnowskiego i proboszcza Padwi, który na ten cel zapisał 7000 zł pol. Jeszcze 17 IX 1696 kapituła tarnowska wyraziła zgodę na erekcję nowej prebendy kanonickiej. Erygował ją 14 III 1698 bp krak. Jan Małachowski ${ }^{199}$. Inne wzmianki: $1725-1785^{200}$.

Patronat: fundator; po jego śmierci kapituła tarnowska wspólnie z burmistrzem miasta Tarnowa ${ }^{201}$.

10. Kanonia fundi Kalembina albo Zontakiewicz, p. w. Najśw. Maryi Panny z Góry Karmel, została ufundowana 6 II 1698 przez ks. Pawła Zontakiewicza, kustosza tarn., który legował na ten cel 5000 zł pol. Kanonię erygowal w r. 1700 zapewne administrator diecezji krakowskiej ${ }^{202}$. W latach 1731-1760 ks. Marcin Matlakowski, kan. fundi Kalembina, wydatnie powiększył uposażenie prebendy przez legat 2000 zł pol. ${ }^{203}$. Inne wzmianki: $1725-1785^{204}$.

Patronat: rada miasta Kęty, przy zgodzie kapituły tarnowskiej ${ }^{205}$.

11. Kanonię p.w. bł. Jana Kantego, dla rektora kolonii akademickiej, ufundowal $\mathrm{w}$ zapisie testamentalnym z 21 XII 1752 - 2 III $1753 \mathrm{ks}$. Wojciech Kaszewicz, scholastyk tarnowski, przeznaczajac na ten cel $4000 \mathrm{z}$ pol. 27 IV 1758 kapituła kolegiacka zgodziła się na fundację nowej kanonij, którą erygował 27 III 1759 bp krak. Ignacy Kajetan Sołtyk. (Por. I $\left.\mathrm{H}_{2}\right)^{206}$. Inne wzmianki: $1760-1784^{\mathbf{2 0 7}}$.

Patronat: rektorat Uniwersytetu Krakowskiego ${ }^{208}$.

12. Kanonia kaznodziejska II ministerii p. w. Przemienienia Pańskiego została ufundowana 10 IX 1766 przez ks. Wawrzyńca Piekosińskiego, dziekana bieckiego, który udotował ją zapisem 10000 zł pol. Fundację tę atoli Piekosiński odwołał i przeznaczył ją na uposażenie scholasterii przy prepozyturze parafialnej w Bieczu ${ }^{200}$. Fundacja następna doszła do skutku dzięki legatom: ks. Jana Wosińskiego, prepozyta tarnowskiego (10000 zł pol. 17 JX 1761), ks. Jana Sokólskiego, kan. tarnowskiego (2000 zł pol. - $18 \mathrm{X}$ 1772), czéści dochodów kanonii kaznodziejskiej I ministerii (4000 zł pol.), ks. Antoniego Dmochowskiego, kan. tarn. (1000 zl pol. - 20 II 1774) oraz

195 AOffic. Vol. 154 (1677) pod data 27 XII 1677. - Por. F. Herzig: Katedra s. 65.

196 Zob. przyp. 194. - ADT: Fasc. Tarnów (kopia z XIX w.).

197 Por. F. Herzig: Katedra s. 65.

198 Z'ob. przyp. 196.

199 Conscriptio nr 42 (reg.). - F. Herzig: Katedra s. 70 n. - Tenźe: Tarnów s. 125.

200 F. Herzig: Katedra s. 71 n.

201 Zob. przyp. 199.

202 Conscriptio nr 112. - Por. F. Herzig: Katedra s. 72 n. (od r. 1700 jako kanonik fundi Kalembina występuje ks. Albert Olszowski). - Tenze: Tarnów s. 126.

203 Por. F. He r zig: Katedra s. 73.

204 Tamże.

205 Tamźe.

206 Zob. przyp. 138.

207 F. Herzig: Katedra s. 86-92. - Tenze: Tarnów s. 161 nn.

208 Zob. przyp. 138.

209 F. H e r z 1 g: Katedra s. 92 n. 
wcieleniu uposażenia parafii Poręba Radlna (5 II 1776), za zgodą jej kolatora ks. Hieronima Sanguszki. Erekcji kanonii dokonał 17 X 1773 bp krak. Ignacy Kajetan Soltyk ${ }^{210}$.

Patronat: prepozyt kapituły kolegiackiej w Tarnowie ${ }^{211}$.

Kanonie honorowe:

Biskupi krak. Jan. Małachowski, Andrzej Stanisław Załuski i Ignacy Kajetan Sołtyk mianowali w latach 1693-1781 8 kanonikow honorowych, bez prebend, którzy mieli prawo zasiadania w stallach, ale nie posiadali głosu na zebraniach kapituły ${ }^{212}$.

I L . Tarnów. Kolegium wikariuszy "manualnych" przy kolegiacie erygował 17 IV 1400 bp krak. Piotr Wysz ${ }^{213}$. Kolegium ,wikariuszy wieczystych" uposażył 16 II 1458 Mikołaj Nos, wojski lwowski, legując na ten cel 200 grzywien. Do beneficjum kolegium inkorporowano nadto: pewne dochody prepozyta $i$ kantora kolegiaty oraz beneficjum altarii św. Jana Chrzciciela (22 IV 1458), za zgodą Jakuba Thycza, ówczesnego altarzysty. 10 VII 1458 erygował kolegium bp krak. Tomasz Strzępiński ${ }^{214}$. 12 V 1542 Piotr Gamrat, bp krak., za zgodą Jana Tarnowskiego, kaszt. krak., wcielił do uposażenia kolegium beneficjum parafialne $w$ Skrzyszowie, co potwierdził $19 \mathrm{~V} 1546$ bp krak. Samuel Maciejowski. (Por. Skrzyszów) ${ }^{215}$. 20 VII 1593 Janusz ks. Ostrogski zezwolił na inkorporację beneficjum plebanalnego w Zalasowej do uposażenia kolegium, co potwierdził 9 III 1594 kard. Jerzy Radziwiłł, bp krak. (Por. par. Zalasowa) ${ }^{216}$. Inne wzmianki: $1470-1785^{217}$.

Za czasów Długosza kolegium liczyło 6 członków. W latach 1513-1577 liczyło ono 7 wikariuszy 13 XII $1660 \mathrm{bp} \mathrm{krak.} \mathrm{A.} \mathrm{Trzebicki} \mathrm{w} \mathrm{dokumencie}$ erekcyjnym prałatury-dziekanii zobowiazał posiadacza tejże do utrzymywania wikariusza wieczystego. Taki wikariusz, siódmy z kolei, był w latach 1666 i 1688. (Por. I $\left.\mathrm{L}_{1-5}\right)^{218}$. 15 III 1663 tenże biskup erygował kanonię prebendarską fundi Książnice i równocześnie jej wikarię, która była ósmą

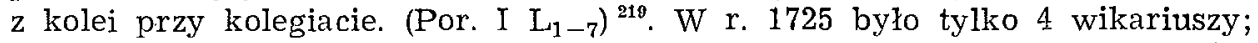
biskup ,zarezerwował sobie na lepsze czasy przywrócenia dawnej liczby kolegium".

Kolegium wikaryjskie było zorganizowane na wzór kapituły, posiadało godności paralelne do urzędów w kapitule większej i stanowiło w kolegiacie „kapitułę mniejszą".

1. Wiceprepozytura została erygowana 17 IV 1400 jako manualna, zaś 10 VII 1458 jako "wikaria wieczysta".

Patronat: prepozyt kapituły tarnowskiej ${ }^{\mathbf{2 2 0}}$.

210 AEp. Vol. 109 (1776: Acta vialia vol. I) s. 19-52. - Por. F. Herzig: Katedra S. 43. - T e n ż e: Tarnów s. 166.

211 Tamże.

212 F. $H \in \mathrm{rz}$ ig: Katedra. s. $94 \mathrm{n}$.

213 ASang. Ir ir 80 s. 94-97.

214 Conscriptio nr 2 (reg.). - F. H e r zig: Katedra s. 27 n. - LBD, I s. 615.

215 ASang. V nr 314 s. $338-343$, nr 341 s. 375 . - Por. F. H e r z i g: Katedra s, 29 n.

216 AEp. Vol. 32 (1592-1596) k. 164-165. - Por. F Herzig: Katedra s. 32. - I u m or: Zanik i afiliacja s. $111 \mathrm{n}$.

217 LBD. - Wiz. 1597-1725; MRPS V/I nr 2726 s. 160 (11 I 1563). - F. H e rzig: Katedra s. $27-38$.

218 Por. F Herz1g: Katedra s. 61.

210 ADT Fasc. Tarnów (kopia dokumentu z 7 V 1663).

220 LBD, I S. 609. 
2. Wicekustodia była erygowana 17 IV 1400 jako manualna, a 10 VII 1458 jako "wikaria wieczysta".

Patronat: kustosz kapituły tarnowskiej ${ }^{221}$.

3. Wicekantoria została utworzona 17 IV 1400 jako manualna, a 10 VII 1458 jako, ,wikaria wieczysta".

Patronat: szlachecki (Tarnowskich) ${ }^{222}$.

4. Wicedziekania została ufundowana łącznie z dziekanatem i erygowana 15 XI 1660. (Por. I L $\left.\mathrm{L}_{1-5}\right)^{223}$.

Patronat: zapewne dziekan kapituly tarnowskiej ${ }^{224}$.

5 Wikaria II prepozyta kolegiaty została utworzona 17 IV 1400 jako „manualna”, a w r. 1458 jako "wieczysta" z obowiązkiem głoszenia kazań w języku niemieckim ${ }^{225}$.

Patronat: Prepozyt tarnowski (do 1458), szlachecki (Tarnowskich) ${ }^{226}$.

6. Wikaria pierwszej prebendy kanonickiej S. Mariae „,n castro" została erygowana 17 IV 1458 jako, "wikaria wiećzysta".

Patronat: kanonik $S$. Mariae in castro ${ }^{227}$.

7. Wikaria prebendy kanonickiej p. w. św. Bartłomjeja została powołana 17 IV 1400 jako ,manualna”, a 10 VII 1458 jako ,wieczysta”.

Patronat: kanonik prebendy p.w. św. Bartłomieja ${ }^{228}$.

8. Wikaria prebendy kanonickiej fundi Łukowa została erygowana 14 IV 1417 jako „manualna” ${ }^{229}$, a 10 VII 1458 jako „wieczysta”.

Patronat: kanonik fundi 壬ukowa ${ }^{230}$.

9. Wikaria prebendy kanonickiej fundi Wierzchosławice została ustanowiona lącznie z omawianą prebendą, 19 XII 1498. Do obowiązków tego wikariusza należało duszpasterstwo $w$ dawnej parafii Wierzchosławice. (Por. $\left.I \mathrm{~L}_{1-4}\right)^{231}$.

Patronat: szlachecki ('Tarnowscy) ${ }^{232}$.

10. Wikaria prebendy kanonickiej fundi Książnice została erygowana, lącznie z prebendą, $7 \mathrm{~V}$ 1663. (Por. I L $\mathrm{L}_{1-7}$ ).

Patronat: zapewne kanonik prebendy fundi Książnice.

Kapituła mniejsza posiadała własne statuty. Najstarsze z nich pochodzą z 6 VIII $1499{ }^{233}$, następne z 3 VII $1532^{234}$. Nowe statuty, w oparciu o dawne, nadał wikariuszom w r. 1595 ks. Krzysztof Kazimierski, prepozyt tarnowski $^{235}$.

221 Tamze s. 611.

222 LBD, I s. 612.

223 Por. F. H erz 1 g: Katedra s. 60.

224 Tamze s. 61.

225 LBD, I 5, 606. - Por. F 11 e r $71 \mathrm{~g}, \mathrm{Jw} . \mathrm{s} .28$.

220 Tamze.

227 LBD, I s. 613.

228 LBD, I S. 614.

220 ASang. II $\mathrm{nr} 103$ s. 121-123.

230 LBD, I s. 615.

231 A.Sang. II $n r 212$ s. 274-277. - Por. F. Herzig, Jw. 43; $\mathrm{Ku} \mathrm{mor:} \mathrm{Zanik} \mathrm{I}$ afiliacja s. 110.

232 Tamze.

233 AKapMK. Rózne wizytacje 1725-1742 k. 243 (gdzie przytoczono caly statut z r. 1499).

234 Tamze k. 240, 243 (gdzle przytoczono statuty).

235 Tamze k. 240-243'. 
I L $\mathrm{L}_{3}$. Tarnów. Kolegium mansjonarzy (pięciu) przy kolegiacie ufundował 20 II 1609, za zgodą króla Zygmunta III Wazy (15 IV 1609), Janusz ks. Ostrogski. Erygowal je 27 VI 1611 bp krak. Piotr Tylicki ${ }^{236}$. 3 XII 1619 kolegium otrzymało własne statuty $\mathrm{z}$ rąk ks. Andrzeja Tarły, prepozyta tarnowskiego ${ }^{237}$. Inne wzmianki $1624-1725-1731-1784^{233}$. W r. 1725 kolegium liczyło tyḷo 3 członków, czwarty miał być instalowany w przeciągu dwóch miesięcy.

Patronat: prawdopodobnie szlachecki.

I L4. Tarnów. Kolegium psałterzystów (pięciu), uposażyła 11 VII 1620 Teofila ze Szczekarzewic, wdowa po Januszu ks. Ostrogskim, legując na ten cel $10000 \mathrm{zl}$ pol. ${ }^{234}$. Erekcji kolegium dokonał 20 III 1621 bp krak. Marcin Szyszkowski ${ }^{240}$. Dalsze wzmianki $1648-1725-1780^{241}$. W r. 1621 instytucja liczyła 5 członków; w r. 1725 tylko 2. Zaniedbaną fundację wznowił, w czasie wizytacji w 1725 r., bp krak. Konstanty Felicjan Szaniawski uzupełniając kolegium do 4 czlonków ${ }^{242}$.

Patronat: prawdopodobnie szlachecki.

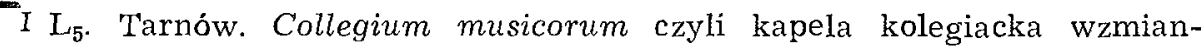
kowana jest w r. $1664^{243}$. 2 III $1689 \mathrm{ks}$. Gawel Kubaszewicz zapisal na uposazenie kapeli kolegiackiej 2000 zł pol., co potwierdził trybunał prymasowski 13 II $1693^{244}$. Dalsze poważniejsze legaty na utrzymanie kapeli poczynili: 9 IX 1690 ks. Kasper Szukocki (200 zł pol.), 9 IX 1692 ks. Stanisław Orłowski (1000 zł pol.) i ks. P. Zontakiewicz (1100 zl pol.), pozostali prałaci i kanonicy tarnowscy w latach $1692-1693$ ok. 2000 zł pol. oraz w r. 1697 kss. Górecki (1000 zł pol.). Do r. 1697 zebrano łącznie na ten cel 18000 zł pol. Dalsze wzmianki: $1695-1775^{245}$.

Patronat: kapituła kolegiacka.

I $\mathrm{M}_{1}$. Tarnów - kolegiata. Altaria p.w. św. Bartłomieja apost. została ufundowana 7 III 1399 przez mieszczanina tarnowskiego Kuńczę, który legował na ten cel 170 grzywien ${ }^{246}$ Erekcji altarii dokonał bp krak. Piotr Wysz przed 1400 r. 17 IV 1400 tenże biskup, za zgodą Jana Tarnowskiego, zniósł altarię, a jej beneficjum przeznaczono na uposażenie prebendy kanonickiej p.w. św. Bartłomieja. (Por. $\mathrm{I} \mathrm{L}_{1-2}$ ) ${ }^{247}$.

Patronat: mieszczański - fundatora, a po jego śmierci — szlachecki (Tarnowskich) ${ }^{248}$.

236 AEp. Vol. 38 (1607-1612) k. 571'-574'. - Conscriptio $\mathrm{nr} 21$ (dokum. $z$ 20 II $1609-$ reg.), $\mathrm{nr} 22$ (dokum. z 15 IV 1609 - reg.). - Wiz. 1725 (reg.). - F. Herzig (Katedra s. 48) podaje, ze erekcja nastapiła I5 IV 1609.

237 AKapMK: Rózne wizytacje 1725-1742 k. 244--246'.

238 Por. F. H e r $z 1 \mathrm{~g}$, jw. S. $48-49$.

239 Wiz. 1725 s. 65 (reg.). - AKapMK. Rózne wizytacje 1725-1742 k. 238 (reg.).

240 ADT: Fasc. Tarnów (kopia z XVIII w.). - Conscriptio nr 31 (reg.). - Por.

F. He r z g, jw. S. $49 \mathrm{n}$.

241 Wiz. 1725. - Status psalteriae 1780 s. 1. - Por. F. Herzig, jw. s. 50.

242 Akta wizytacji 1725 s. $15 \mathrm{n}$.

293 Wiz, 1664 s. 560: Missa solemnis cum cantu musicorum celebrari.

244 Conscriptio nr 110 (reg.). - Por. F. H e rzig: Katedra s. 67.

245 Conscriptio nr 76 (reg. dokum. z 5 XII 1693). - Zob. F. He r zig, jw. s. 66-69, $71,25,121$.

248 ASang. II nr 78 s. 91 n. - Por. F. Her zig, Jw. s. 9.

247 ASang. II $\mathrm{nr} 80$ s. 94-97. - LBD, I s. 614.

248 Zob. przyp. 246. 
I $\mathrm{M}_{2}$. Tarnów -- kolegiata. Altaria p. w. Bożego Ciała, lub téź św. Krzyża została ufundowana w 1. 1395-1397 przez Spytka († 1395/97), podkomorzego krak. ${ }^{29}$. 17 IV 1400 bp krak. Piotr Wysz zniósł ją, a jej uposażenie przeznaczył dla nowoerygowanej kustodii ${ }^{25 n}$. (Por. $1 \mathrm{~L}_{1-2}$ ).

Patronat: szlachecki ${ }^{251}$.

I $\mathrm{M}_{3}$. Tarnów - kolegiata. Altaria p. w. św. Barbary p. i m. została ustanowiona 13 VII 1415 przez Jana Tarnowskiego, który na jej uposażenie przeznaczył 8 grzywien rocznego dochodu ${ }^{252}$. Za zgodą Jana Amora Tarnowskiego (22 I 1494 i 28 IV 1498) kard. Fryderyk Jagiellończyk zniósł 19 XII 1498 altarię, a jej beneficjum, połączone $\mathrm{z}$ parafialnym $\mathrm{w}$ Wierzchosławicach, przeznaczył na nową prebendę kanonicką fundi Wierzchosławice p. w. św. Barbary. (Por. I $\mathrm{L}_{1-4}$ ). Inne wzmianki: 1513, 1527, 1539, 1561, 1577.

Patronat: szlachecki ${ }^{253}$.

I $\mathrm{M}_{4}$. Tarnów - kolegiata. Altaria p. w. św. Jana Chrzciciela została uposażona przez Tarnowskich przed r. 1458, którzy udotowali ja folwarkiem na Przedmieściu Tarnowskim i 4 grzywnami rocznych odsetek ${ }^{254}$. $22 \mathrm{VI}$ 1458 ks. Jakub Thycz, aktualny altarzysta, za zgoda jej patrona, Jana Amora Tarnowskiego, przystał na inkorporację swej altarii do uposażenia kolegium wikariuszy. Inkorporacji dokonał 10 VII 1458 bp krak. Tomasz Strzępiński ${ }^{255}$. (Por. I L $\mathrm{L}_{2}$ ).

Patronat: szlachecki (Tarnowskich) ${ }^{250}$.

I $\mathrm{M}_{5}$. Tarnów - kolegiata. Altaria p. w. Bozego Ciała I ministerii została ufundowana 9 III 1497 przez Jana Amora Tarnowskiego, za zgodą króla Jana Olbrachta; fundator przeznaczył na ten cel 10 grzywien rocznego dochodu ${ }^{257}$. Innych danych brak.

Patronat: szlachecki (Tarnowskich) ${ }^{258}$.

I $\mathrm{M}_{6}$. Tarnów - kolegiata. Altaria p. w. św. Anny I ministerii została uposażona $20 \mathrm{~V} 1514$ przez Jana Zalasowskiego, mieszczanina tarnowskiego, który przeznaczył na ten cel 200 zł pol. ${ }^{259}$. Inne wzmianki: 1513, 1527, 1529, $1539,1561,1577$.

Patronat: mieszczański (1525), szlachecki ${ }^{260}$.

I $M_{7}$. Tarnów - kolegiata: Altaria p. w. św. Jana Apost. i Ewang. istniała w latach 1513, 1527, 1529, 1539, 1561, 1577.

Patronat: nieznany.

I $\mathrm{M}_{8}$. Tarnów - kolegiata. Prebenda dla kaznodziei została uposażona

249 A Sang. II nr 80 s. 94-97. - Por. F. Herzig: Katedra s. 19. - W. D w orzac z e k: Genealogia. Warszawa 1959 k. 96.

250 Tamze.

251 Tamze.

252 KDKK, II $\mathrm{nr} 561$ s. $402-403$.

253 Tamze.

254 F. H erzig: Katedra s. 28.

255 LBD, I s. 606, 616. - Por. F. H e r $21 \mathrm{~g}$, Jw. S. 28.

256 Tamze.

257 ASang. II $\mathrm{nr} 209$ S. 265 n. - MRPS, If $\mathrm{nr} 658$ s. 40 (reg.). - Por. F. HIerzig, Jw. s. 41.

258 Tamze.

259 AEp. Vol. 7 k. 294. - Por. F. Herzlg, Jw. S. 45 n.

260 AOffic. Vol. 58 (pod datą $23 \mathrm{~V}$ 1525. Jurıs patronatus altaris s. Annae in ecclesia Tarnoviensis donatio). 
26 III 1530 (400 zł pol.) ${ }^{261}$. Erygował ją w 1535 r. bp krak. Piotr Tomicki ${ }^{262}$. W r. 1559 Jan Amor Tarnowski zgodził się na inkorporację beneficjum parafialnego w Łękawicy do uposażenia kaznodziei, co też wkrótce nastąpiło (por. Łękawica) ${ }^{263}$. 17 VI 1622 bp krak. Marcin Szyszkowski inkorporował beneficjum kaznodziei do uposażenia kaznodziejskiej prebendy kanonickiej I ministerii. (Por. I $\mathrm{L}_{1-6}$ ).

Patronat: kapituła tarnowska ${ }^{264}$ :

I $\mathrm{M}_{9}$. Tarnów - kolegiata. Altaria p. w. Bożego Ciała II ministerii została ufundowana w r. 1651 przez Bełerowskiego, który legował na ten cel 600 fl. pol.; erygował ją 30 VIII 1651 bp krak. Piotr Gembicki ${ }^{265}$.

Inne wzmianki: $1685^{266}$.

Patronat: prepozyt kapituły tarnowskiej ${ }^{207}$.

I $\mathrm{M}_{10}$. Tarnów - kolegiata. Altaria p. w. św. Agnieszki p. i m. przy ołtarzu św. Anny II minısterii została uposażona w r. 1653 przez Agnieszkę Paszerową, która na ten cel przeznaczyła ,połowę domu w Tarnowie i 4 pręty roli". 29 V 1654 altarię erygował bp krak. Piotr Gembicki ${ }^{268}$. 19 II 1685 zniósł altarię bp sufr. krak. Mikołaj Oborski, a beneficjum jej wcielił do prebendy kanonika penitencjarza. (Por. I $\mathrm{L}_{1-8}$ ).

Patronat: rada miasta Tarnowa ${ }^{269}$.

I $\mathrm{M}_{11}$. Tarnów - kolegiata. Prebende dla kapelana bractwa Szkaplerza św. uposażył 15 III 1652 Kilian Bałkowicz, wójt tarnowski, przeznaczając na ten cel 2000 zl pol. Erygowal ją $29 \mathrm{~V} 1654$ bp krak. Piotr Gembicki ${ }^{270}$. Inne wzmianki: $1660,1725,1741^{271}$.

Patronat: fundatora; po jego śmierci - rady miasta Tarnowa ${ }^{272}$.

I $\mathrm{M}_{12}$. Tarnów - kolegiata. Altaria p. w. Przemienienia Pańskiego i św. Józefa Obl. NMP została uposażona 9 IV 1677 przez Kazimierza Kulwińskiego, który na ten cel legował $4000 \mathrm{zł}$ pol. ${ }^{2 / 3}$. Erekcji altarii dokonal w r. 1677 bp krak. Andrzej Trzebicki ${ }^{274}$. Altarię te prezentowano kanonikowi kaznodziei I ministerii. Inne wzmianki: 1712, 1715, $1763^{275}$. (Por. I $\mathrm{L}_{1-12}$ ).

Patronat: nieznany, prawdopodobnie kapituła tarnowska ${ }^{\mathbf{2 7 6}}$.

I $\mathrm{M}_{13}$. Tarnów - kolegiata. Altaria p. w. św. Krzyża została ufundowana 14 VII 1698 przez ks. Grzegorza Nadkańskiego, archid. tarnowskiego,

201 AEp. Vol. 12 (1530) k. 17.

262 AEp. Vol. 15 (1524-1536) k. 174. - Conscriptio nr 34 (reg. dokum. z 1535). - Por.

F. Herzig: Katedra s. 52.

$263 \mathrm{Ku} \mathrm{mor:} \mathrm{Zanik} \mathrm{i} \mathrm{afiliacja} \mathrm{s.} \mathrm{111.} \mathrm{-} \mathrm{F.} \mathrm{Herzig,} \mathrm{Jw.} \mathrm{s.} 53$.

264 Zob. przyp. 261-263.

265 AEp. Vol. 56 (1650-1651) k. 737'-741. Conscriptio nr 60 (reg.).

266 F. H e rzlg, jw. s. 47.

267 Zob. przyp. 265.

268 AEp. Vol. 58 (1653-1655) k. 484-489. - Conscriptio nr 17 (reg.) - Por. F. H e I z 1 g,

jw. s. 46 .

269 Tamze.

270 AEP. Vol. 58 (1653-1655) k. 479-484. - Conscriptio nr 55 (reg.).

271 AEp. Vol. 60 (1660-1661) k. 463 (dokum. z 13 X 1660). - Wiz. 1725. - F. He $\mathrm{z}$ ig:

Katedra s. 59 n. (gdzie przytacza inwentarz kapelanii bracklej z r. 1741).

272 Tamże.

273 APBern. Sygn. XIV-a-1: Archivium Conventus 1657 s. 25-27. - F. H e r z i g, fw. S. $55,93$.

274 Conscriptio nr 48 (reg.).

275 F. H e r zig, jw. s. 55.

276 Tamze. 
który na ten cel zapisał $2000 \mathrm{zł}$ pol. ${ }^{277}$. Erekcja altarii nastąpiła w r. $1701^{278}$. Altarię mial otrzymać jeden z wikariuszy kolegiaty.

Patronat: prepozyt tarnowski na wniosek kapituły mniejszej, po wysłuchaniu zdania kapituły większej ${ }^{279}$.

I $\mathrm{M}_{14}$. Tarnów - kolegiata. Altaria p. w. bł. Jana Kantego została uposażona w latach 1749-1752 przez ks. Jana Kantego Wosińskiego, prepozyta tarnowskiego, który na ten cel przeznaczył $2000 \mathrm{zl}$ pol. ${ }^{28 ?}$.

Patronat: prepozyt tarnowski ${ }^{281}$.

I N. Tarnów. Przy klasztorze bernardyńskim p. w. NMP Śnieżnej, w kaplicy p.t. Chrystusa w Ciemnicy, znajdował się w 1702 r. słynący łaskami obraz Chrystusa Miłosiernego ${ }^{282}$.

VI C. Żydzi mieszkali w mieście już w pierwszej polowie XVI w. $(1545)^{283}$. W r. 1631 posiadali oni własny cmentarz ${ }^{284}$.

VI D. Synagogę wybudowali Żydzi w r. $1661^{285}$. Około r. 1665 została ona strawiona przez pożar. 8 VII 1665 bp krak. Andrzej Trzebicki zabronił odbudowy synagogi ${ }^{286}$. Przed r. 1677 synagoga była odbudowana ${ }^{287}$. Inne wzmianki: $1695,1713,1717,1738,1739{ }^{288}$.

\section{PARAFIA TUCHÓ (miasto)}

Źródła przekrojowe: MPV I i II (1325-1358); Gromnicki: Swiętopietrze s. 366 n. (1328-1358), 1373-1374, 1551-1560); LBD, II s. 272, 299; III s. 183, 198-200, 222-224; LR 1513 k. 23; LR 1527 k. 48; LR 1529 s. 101; Rej. pob. 1536 s. 548 n.; LR 1539 k. 22; LR 1561 k. 34; Regestrum 1570 s. 193; LR 1577 k. 84'; Rej. pob. 1581 s. 265 , 266; Wiz. 1596 k. 23-24'; Syn. 1621 s. 28; Wiz. 1637 k. $373^{\prime}-374$; Starowolski $1655 \mathrm{k} . \mathrm{B}_{4}, \mathbf{E}_{3}{ }^{\prime}$; Wiz. 1664 s. 494-498, 538-540; Wiz. 1665 s. 12-13; Wiz. 1669 k. 2-9; Syn. 1711 s. 15 ; Wiz. 1748 k. 84-89.

Inne źródła: ADT: 1: Fasc. Tuchów (or. i kop. XIV-XIX w.); 2. Fasc. Benedyktyni w Tuchowie (or. i kop. XVI-XVIII w.); 3 . Inwentarz dworu Siedliskiego z 1732 r.; 4. Convolutum actorum visitationis ecclesiae parochialis in Tuchów ex an. 1814; 5. Ordinationes pro praepositura Tuchoviensi ex $18 \times 1706 ; 6$. Catalogus documentorum in archivo parochiali Tuchoviensi an. 1850 reperibilium; 7. Recepisse super sequentibus documentis ecclesiae parochialis Tuchoviensis ex an. 1842; 8. Summarium documentorum ecclesiae Tuchoviensis BMV Visitationis - - in suburbio oppidi Tuchów - consignatum die 25 I 1785; 9. Suplika pospólstwa miasteczka Tuchowa do konwentu tynieckiego ( $\mathrm{z}$ XVIII w.); 10. Pergaminy (bez sygn.). - APar. w Tuchowie: 1. Summa legum S.C.R. Ap. Maj. - - singulis eccle-

277 Testis 1763 s. 25. - F. H e r z 1 g, jw. s. 69

278 Conscriptio $\mathrm{nr} 54$ (reg.).

279 F. Herzlg, jw. s. 69.

280 Tamże s. 83.

281 Tamze.

k. 171 .

282 APBern. Sygn. XIV-h-1: Akta rózne klasztoru Bernardynów w Tarnowie (Wiz. 1702)

283 AAdm. Vol. 3 (1545-1546) k. 244 (dokum. $\mathrm{z} 23 \mathrm{X}$ 1545).

284 F. H erzig: Tarnów s. $135 \mathrm{n}$.

285 Conscriptio nr 59 (reg.).

280 AEp. Vol. 61 (1661-1666) k. 692, 698.

287 APBern. Sygn. XIV-a-1: Archivium Conventus Tarnoviensis 1657 s. 25-27 (dokum z 9 IV 1677).

288 Tamze s. $27-31$ (dokum. z $25 \mathrm{X}$ 1713), 31-32 (dokum. z I IX 1645), 81-83 (1738), 83-85 (1739). - Por. F Herzig: Tarnów s. 138 (1717). 
siis parochialibus in Galicia transmissa 1781-1816; 2. Chronicus conspectus ecclesiae Tuchoviensis ab initio saeculi XIV usque ad augustum 1849 anni - - per J. C. Guszkiewicz vic. coop. Tuchov., 3. Liber memorabilium (z XIX i XX w.). Archiwum klasztoru $w$ Tuchowie: 1. V-26: Acta fundationis ecclesiae et prioratus ad thaumaturgam Tuchoviensem - conscripta a. 1767, 2. Liber privilegiorum, legum et constitutionum confraternitatis Immaculatae Conceptionis BMV in ecclesia Tuchoviensi s. t. Visitationis BMV - - A. D. 1699 conscriptus; 3. Album confraternitatis Immaculatae Conceptionis BMV - - a. 1699. - Bibl. Ossol. Sygn. 3695/II: Metrica sive copiae privilegiorum et literarum super bona monasterii Thinecensis - - $1602 \mathrm{k}, 12,13,62,56,61$ (1560-1579). - KDMP, IV (indeks). KDT, I i II (indeks).

Ważniejsze opracowania: S. Szczygielski: Tinecia seu historia monasterii Tinecensis. Cracoviae 1668. - O. W. Szołdrski CSSR: Historia kościoła i cudownego obrazu Najśw. Panny w Tuchowie. Cieszyn 1920. - B. M i etus: Historia kościoła parafialnego w Tuchowie (rkps). - A. Hirs chberg: Stosunki osadnicze. - O. M. W it a lis: Kościół N. M. Panny w Tuchowie. Architektura i wyposażenie. Miejsce w przemianach sztuki polskiej. Kraków 1960 (maszynopis). - F. Krogulski: Monografia Tuchowa (maszynopis). - W. Wojciec how ski: Monografia Tuchowa (rkps).

I A. Osada wymieniona w obrębie posiadlości benedyktynów tynieckich w latach 1123/25, 1229 i $1288^{1}$. Zawdzięcza ona swój rozwój pokładom soli, które w średniowieczu były eksploatowane ${ }^{2}$. 2 XI 1340 osada, za zgodą Kazimierza Wielkiego, otrzymala miejskie prawo niemieckie ${ }^{3}$.

Parafia, fundacji benedyktynów tynieckich, powstała w w. XII ${ }^{4}$; pierwsza wzmianka z r. $1321^{5}$. 14 VI 1456 bp krak. Tomasz Strzępiński, na prośbę opata tynieckiego Macieja, inkorporował parafię, wraz $z$ uposażeniem, do opactwa benedyktynów w Tyńcu, duszpasterstwo zaś w parafii oddal benedyktynom $^{6}$. 2 X 1456 pap. Kalikst II, bullą Disposıtione divina gregi, zgodził się na inkorporację parafii do opactwa benedyktynów tynieckich i utworzenie $w$ Tuchowie prepozytury zakonnej; wykonanie postanowienia zlecił Michałowi z Lipia, opatowi świętokrzyskiemu '. Po śmierci ks. Daniela, ostatniego kapłana diecezjalnego, spór o wykonanie dekretu biskupa i bulli papieskiej rozpoczął się na nowo. 3 IX 1458 pap. Pius II, bullą Rationi congruit, polecił Janowi Pniewskiemu, archidiak. krak. oraz Pawłowi, archidiakonowi włocł. i pomor., aby wprowadzili na probostwo w Tuchowie ks. Mikołaja z Lublina, kapłana diec. krak. ${ }^{8}$. Atoli już 28 IX 1458 tenże papież, listem apostol. Dispositione divina, polecil Mikolajowi z Lipia, opatowi świętokrzyskiemu wcielić probostwo tuchowskie do opactwa tynieckiego i erygować tam prepozyturę zakonną ${ }^{9}$. 27 XI 1458 archidiakon Paweł, z polecenia pap.

1 CDT nr 1 s. 1 mn. (1105). - MPH, I s. 516-520 (1105). - Por. Z. K o z low s a Budkow a: Repertorıum polskich dokumentów doby piastowskiej. Z. 1. Kraków 1937 nr 26 s. 29-33 (gdzie podano bibliografię). - CDT nr 116 s. 21 nn. (1229 - podejrzany); nr 36 s. 70-75 (1288 - podejrzany). - MPH, I s. 516-520. - Por. A. H 1 r s c h b e r g: Stosunki osadnicze s. 34 .

2 CDT nr 58 (1340). - LBD, III s. 200. - sz c z y g 1 e $1 \mathrm{sk}$ k: Tinecia s. 239.

3 CDT nr 58 s. $97-99$.

$4 \mathrm{Ku} \mathrm{mor:}$ : Powstanie i rozwój siecı s. 519.

5 KDKK, II $n$ r 243 s. 2-3 (dokum. z $29 \mathrm{~V} 1321$ - Saulo de Tuchow plebano).

6 CDT nr 217 s. 400-402. - Por. O. W. S z old r ski: Historia s. 3 nn.

7 CDT hr 218 s. $402-405$.

8 Tamze nr 222 s. $414-q 17$.

9 CDT nr 223 s. $417-421$. 
Piusa II, znowu nakazał oddanie parafii w Tuchowie ks. Mikołajowi z Lublina ${ }^{10}$. W wyniku apelacji opata tynieckiego do Rzymu, pap. Pius II powołal komisję w sprawie zatargu ${ }^{11}$. 29 XI 1458 Bernard de Bostho, kan. wardeński $i$ audytor kurii rzymskiej, rozstrzygną spór o parafię $w$ Tuchowie między opactwem tynieckim a ks. Mikołajem z Lublina na korzyść tego ostatniego ${ }^{12}$. Jednakże 6 X 1459 Michał z Lipia, opat świętokrzyski, jako delegat papieski, przysądził ponownie parafię tuchowską opactwu tynieckiemu i polecil przekształcić ją na prepozyturę zakonną ${ }^{13}$. 15 II $1460 \mathrm{bp} \mathrm{krak.}$ Tomasz Strzępiński powtórnie włączył parafię do opactwa tynieckiego i przekazał benedyktynom duszpasterstwo w parafii ${ }^{14}$. 25 X 1460 Sancjusz Romeo, audytor kurii rzymskiej przywołał odnowiony spór o parafię tuchowską przed trybunał Stol. Apost. ${ }^{15} 16$ II 1461 trybunał rzymski uwolnił opactwo tynieckie od ciążących na nim kar kościelnych z racji sporu ${ }^{16}$, a 26 II 1461 pap. Pius II, bullą Pastoralis officii debitum, kładąc koniec sporom, polecił opatowi koprzywnickiemu Mikołajowi przekształcić parafię „świecką" (saecularem) w Tuchowie na ,zakonną" (regularem) ${ }^{\mathbf{1}}$. Odtąd aż do r. 1810 parafią administrowali benedyktyni ${ }^{18}$.

Patronat: opactwo benedyktynów w Tyńcu ${ }^{10}$.

I B. Okręg parafialny za czasów Długosza ${ }^{20}$ obejmował miasto Tuchów oraz wsie: Lubaszowa, Siedliska ${ }^{21}$, Meszna, Dąbrówla, Golanka, Bistuszowa, Burzyn, Meszna, Buchcice, Kielanowice. W latach 1461--1470 został wydzielony $\mathrm{z}$ tejże parafii okreg paraf. Piotrkowice. (Por. Piotrkowice). W r. 1536 wymieniono tylko miasto Tuchów oraz wsie: Buchcice i Meszna, a w r. 1581 nadto: Godna, Bączałka i Tułkowice(?) W latach 1596-1664 do parafii należały miasto Tuchów oraz wsie: Meszna, Siedliska, Dąbrówka, Lubaszowa, Burzyn (1664 media Burzyn), Kielanowice, Głęboka (1596 — Głęboczka) j Garbek. Wiz. 1748 informuje, że „do parafii należą miasto i tylko 3 wioski”.

I C. W połowie XIV w. ludność parafii szacuje się na 705 osób ${ }^{22}$. W r. 1662 samo miasto Tuchów liczyło 193 mieszkańców ${ }^{23}$. W r. 1664 do komunii wielkanocnej przystąpiło łącznie z całej parafii 1250 osób, w tym z Tuchowa - 400, Mesznej - 160, Siedlisk - 200, Dąbrówki - 100, Lubaszowej - 80, Burzyna - 100, Kielanowic - 100, Buchcic i Głębokiej - 60 oraz z Garbku — 50. W r. 1748 przyjęło komunię wielkanocną „przeszło tysiąc osób". W r. 1802 we wsi Garbek zamieszlkiwało 257 osób, Dąbrówka 444. Podkościelany - 194, Siedliska - 793, Lubaszowa -- 234, Gadówka - 76 (lącznie 1998) ${ }^{24}$.

10 Tamze nr 224 s. $421-425$.

11 ADT. Dokumenty (oryg. perg., $51 \times 38 \mathrm{~cm}$, preczęc wisząca).

12 CDT nr 225 s. $425-431$.

13 Tamze nr 226 s. $431-437$.

14 CDT nr 227 s. $438-442$.

15 Tamże $\mathrm{nr} 228$ s. $442-449$.

16 CDT nr 229 s. $449-453$.

17 Tamze nr 230 s. 253-256.

18 Schematismus 1863 s. 29. - Schematismus 1875 s. 61.

19 Zob. przyp. 6-16. - LBD. - Wiz. 1596-1748.

20 Przekroje: LBD, 1536, 1581, 1596, 1664, 1748.

21 Wioski te nalezały do parafii juz w r. 1376 (ADT- Fasc. Tuchów - dokum. z 18 III

1376. - Por. M. N 1 w 1 ís k 1: Archıwum s. 207).

22 Ła d ogó r s k 1: Studia s. 201.

23 A. P a w 1 ń $\mathrm{k}$ i. Polska XVI wleku. T, 3 s. 52.

24 Summa legum s. 65-66. 
I D. Kościół parafialny do r. 1460 był poza miastem i ,za rzeką Białą"; był drewniany i p. w. Najśw. Maryi Panny ${ }^{25}$. W r. 1460 parafia została przeniesiona do kościoła św. Jakuba ap. w mieście ${ }^{26}$. Za czasów Dlugosza kościól był "drewniany i konsekrowany". Można przypuścić, że spalił się w $1494 \mathrm{r}$., w czasie pożaru miasta ${ }^{27}$. W latach $1570-1596-1637$ „kościól był drewniany i konsekrowany". W r. 1664 ,był murowany - - lecz jeszcze ściany, sklepienie i okna niewykończone; tylko niewielka część wykończona". W r. 1669 "murowany, lecz sklepienie niewykończone". Wykończono go przed r. 1683. Konsekrował go 11 XI 1683 bp sufr. krak. Mikolaj Oborski ${ }^{28}$. W r. 1748 był ,kościół murowany, dawniej budowany, w dużej części zrujnowany". W r. 1789 kościół spalił się. Nowy, również murowany, wybudował w latach $1791-1800 \mathrm{ks}$. Odo Kontentowicz, benedyktyn i miejscowy prepozyl ${ }^{20}$. Konsekrował go w 1824 r. bp tyniecki Grzegorz Tomasz Ziegler.

Wezwanie: Najśw. Maryja Panna (Nawiedzenie - do 1460) ${ }^{30}$. Sw. Jakub apostoł $^{31}$.

I $E_{1}$. Tuchów. Klasztor benedyktyński, przy 'kościele Nawiedzenia NMP, został wybudowany po r. $1780^{32}$. W r. 1748 mieszkało w nim 4 kapłanów zakonników. Rezydował tu ostatni opat tyniecki, późniejszy bp tarnowski Florian Amand Janowski (1786-1801) ${ }^{\mathbf{3 3}}$.

I E $\mathrm{E}_{\mathbf{2}}$. Tuchów. Kościół p. w. Nawiedzenia NMP, „poza miastem, za rzeką Białą", dawny parafialny (do 1460 r. - por. I D) byl w latach 1570-15961637-1664-1669 drewniany i konsekrowany. Kościól murowany został wystawiony przez Adama Gloniskiego, burgrab. krak., ,na gruncie przez benedyktynów odstąionym", w latach 1677-1682 ". Konsekrował go 8 IX 1687 bp sufr. krak. Mikołaj Oborski ${ }^{35}$. W r. 1700 kościól został rozbudowany, przez wybudowanie od strony północnej kaplicy p. w. SS. Barbary i Antoniego. W tym samym roku odbudowano kaplice od strony poludniowej p. w. Niepokalanego Poczęcia NMP ${ }^{36}$. W r. 1748 ,kościół był największym ze wszystkich w mieście, murowany, obsługiwany przez 4 kapłanów - benedyktynów". W r. 1785 sporządzono kopiarz dokumentów dotyczących kościoła i parafii ${ }^{37}$.

I $E_{3}$. Tuchów. Kościół św. Marii Magdaleny, „na cmentarzu kościelnym”

$25 \mathrm{CDT}$ nr 217-230 (1456-1461). - Wiz. 1664 r. s. 539.

26 Wiz. 1664 s. 539: ,Extra oppidum post fluvium Bikla est capella lignea, quondam parochıalis ecclesia, prout legitur in erectione translatae parochialis ad oppidum et praepositurae regularıs in anno Domıni 1460". Por. CDT nr 230 (1461 - ecclesia S. Marıae). - LBD, III s. 222 (ecclesıa b. Jacobi ap.).

27 Por. MRPS, II nr 396 s. 24 (reg. dokum. z 1 VII 1494).

28 Wiz. 1728 k. 84.

20 Schematismus 1863 s. 30.

30 Zob. przyp. 25.

31 LBD, III s. 199, 222. - Regestrum 1570. - Wiz. 1596-1748. - Elenchus omnium parochiarum $1785 \mathrm{nr} 12$.

32 O. W. S z o $1 \mathrm{dr} \mathrm{ski}$ : Historia s. 41.

33 Ks. B. K u m or Janowski Florian. Pol. slow, biogr. $X$ s. 563 . - K u mor: Dzieje S. $48 \mathrm{nn}$.

34 O. W. Szoldrski: Historia s. $26 \mathrm{nn}$. - K. Czemeryński: O dobrach koronnych bylej Rzeczypospolitej. Lwów 1270 s. 64.

35 ADT. Fase. Dokumenty benedyktynów w Tuchowle (kopla). - o. W. Szołdrski, JW. S. 193.

36 O. W. Szold s s i, jw. s. 32,35 .

37 Stummarium documentorum z 25 I 1785. 
(przy kościele NMP); kaplica drewniana, została wybudowana już w r. $1496{ }^{38}$. W r. 1596 ,oltarze w niej były konsekrowane, lecz zniszczone, bez portatylów, kaplica zaś na skutek wichury częściowo zniszczona". Prawdopodobnic ok. 1640 r. zostala ona wyrestaurowana. 20 X 1646 pap. Innocenty X udzielił kościołowi przywilejów odpustowych, na co wyraził zgodę 18 XII 1646 bp krak. Piotr Gembiski ${ }^{39}$. W r. 1596 w kościele nie odprawiano nabożeństw. W latach 1646-1664 sprawowano służbę Bożą. W r. 1669 „kościół potrzebował naprawy". W r. 1748 zaznaczono, że ,kaplica nowa została zbudowana przez poprzedniego prepozyta". Istniała ona jeszcze w r. $1814^{40}$.

I $E_{4}$. Tuchów. Kaplica p. w. św. Anny istniała już w r. $1570^{41}$. W r. 1596 była ona "drewniana i konsekrowana". W r. 1664-1669 „kaplica, niepoświęcona, - - służba Boża w niej się odprawia na mocy indultu". Wizytator w r. 1748 zaznaczyl, że ,kaplica jest drewniana, bardzo stara, całkiem rozpadła się, nie posiada żadnego uposażenia".

I $E_{5}$. Tuchów. W r. 1570 istniała kaplica św. Leonarda ${ }^{42}$. Innych wzmianek brak.

I E $E_{6}$ Tuchów. Kaplica p. w. św. Marka była w r. 1596 „drewniana i konsekrowana". Innych wzmianek brak.

I $E_{\eta}$. Siedliska. Kaplice drewniana wybudował w 1706 r. Kazimierz Szaniawski, łowczy łukowski; 23 III 1707 została ona poświęcona ${ }^{43}$. Istniała jeszcze w r. $1732^{44}$.

I F. Tuchów. Szpital wzmiankowano pierwszy raz w r. $1575^{45}$. 19 VII 1596 otrzymał on legat $200 \mathrm{zl}$ pol. z rak Andrzeja Śreniawy, ,aby za to kupiono na rzecz ubogich folwark Wojciecha Młynarza" ${ }^{46}$. W tymże roku szpital "stał obok głównego kościoła, był w stanie dobrym" (Wiz. 1596). W r. 1664 ,szpital drewniany składał się z 3 izb, dobrze pokryty". W r. 1748 ,szpital znajdował się na gruncie kościelnym; kościoła szpitalnego nigdy nie było". W r. 1664 w szpitalu mieszkało 12 ubogich, a w 1748 - tylko 9.

I $G_{1}$. Tuchów. Bractwo Różańca św. zostało zaprowadzone przed r. 1637. Przed r. 1664 otrzymało ono własnego promotora (kapelana) i kaplicę w kościele parafialnym. 16 III 1729 Stanisław Sasakowicz powięszył uposażenie kapelanii brackicj (100 fl. pol. $)^{47}$.

Inne wzmianki: $1669,1706,1748^{48}$.

$I_{G_{2}}$. Tuchów. Bractwo Niepolalanego Poczęcia NMP, przy kościele $\mathrm{Na-}$ wiedzenia NMP, zostało zaprowadzone w r. $1698^{49}$. Papieże - Innocenty XII, bulle Cum sicut accepimus i Omnium salute paterna (12 IX 1698) i Klemens XI, kullą Universis Christi fidelibus (30 IV 1707) obdarzyli bractwo

38 Convolutum actorum 1814 (reg.).

39 ADT: Dokumenty (or. perg. $41 \times 14 \mathrm{~cm}$, bez pleczęci).

40 Convolutum actorum 1814 (reg.).

41 Regestrum 1570 s. 193.

42 Tamze.

43 ADT: Fasc. Dokumenty benedyktynów $\cdot \mathrm{W}$ Tuchowie (reg.).

14 Inwentarz dworu siedliskiego z r. 1732 s. 1.

45 ADT: Fasc. Tuchów (kopıa dokum. z 3 VIIr 1575: Andrzej Brzechwa, opat tyniecki. oddaje miastu Tuchów łaźnie).

46 Tamze (kopia dokum. z XVII w.). - Dokumenty bened. w Tuchowie (kopla

7. XVIII w.). - Catalogus documentorum $1850 \mathrm{nr} 87$ (reg.).

47 Summarium documentorum $\mathrm{nr} 4$ (reg.).

48 Ordinationes pro praepositura Tuchoviensi ex 18 X 1700 s. 1 (reg.).

49 AD' Fasc. Benedyktyn w Thichowie (lsopra dokum. z 1698). 
licznymi odpustami ${ }^{50}$. $8 \mathrm{X} 1704 \mathrm{bp}$. Kazimierz Eubieński, administrator diec. krak., erygował kapelanię (promotorię) bracką ${ }^{51}$. Inne wzmianki: 1706, $1748{ }^{\mathbf{5 2}}$. (Por. I $\mathrm{M}_{1}$ ).

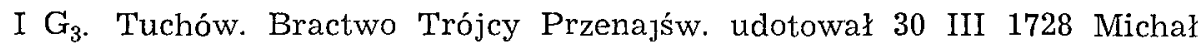
Burzyński, przeznaczając na ten cel $1000 \mathrm{fl}$. pol. ${ }^{53}$. Wzmianka: 1748.

$\mathrm{I} \mathrm{G}_{4}$. Tuchów. Cech rzeźników załozył i przepisał mu statuty 19 XII 1514 opat tyniecki Stanisław ${ }^{54}$. Inne wzmianki. 1529, w. XVIII ${ }^{55}$.

$I_{5}$. Tuchów. Inne cechy (,cechmistrze wszystkich cechów”) istniały w 1637 r. i w XVIII w. ${ }^{56}$.

I H. Tuchów. Szkoła parafialna istniała za czasów Długosza ${ }^{57}$. W r. 1596 „budynek szkolny był w złym stanie". W r. 1664 szkola "stała kolo cmentarza kościelnego", uczęszczało do niej 30 chłopców ${ }^{58}$. W r. 1748 ,budynek szkolny spalony"; ponieważ "nie było także kierownika szkoły, stąd nie było również żadnych uczniów”. Inne wzmianki: 1513, 1527, 1539.

I J. Tuchów. Pielgrzymki do łaskami słynącego obrazu NMP w kościele p. w. Nawiedzenia były juz znane w r. 1596; w tymże roku na uroczystościach odpustowych 2 lipca liczono ,prawie 15 tysięcy pielgrzymów". Wiz. 1665 informuje, że „na wielkie proczystości, a szczególnie w oktawie Nawiedzenia NMP, przybywają tu tłumnie pątnicy i kapłani zakonni i diecezjalni dla słuchania spowiedzi św."

I $\mathrm{M}_{1}$. Tuchów. Prebenda dla promotora bractwa Różańca św. została utworzona przed r. 1664. 16 III 1729 uposażenie prebendy zostało powiększone. Inne wzmianki: 1664, 1669, 1706, 1748. (Por. I G $\mathrm{G}_{1}$ ).

Patronat: nieznany.

I $\mathrm{M}_{2}$. Tuchów. Prebenda dla promotora bractwa Niepokalanego Poczęcia NMP, przy kościele Nawiedzenia NMP, została uposażona 10 III 1704 przez Jana Szaniawskiego i jego żonę Teresę, którzy na ten cel legowali 10000 fl. pol. ${ }^{59} 8 \times 1704$ erygował ja adm. diec. krak., bp Kazimierz Eubieński ${ }^{60}$. (Por. I $\mathrm{G}_{2}$ ).

Patronat: nieznany ${ }^{61}$.

I L. Tuchów Obraz NMP, słynący łaskami, wymieniają Wiz. 1596-1748 ${ }^{\text {*2. }}$. $27 \mathrm{~V} 1641 \mathrm{bp}$ krak. Jakub Zadzik powołał komisję celem zbadania łask doznanych przy obrazie ${ }^{63}$. Komisja wydała wyrok pozytywny 12 VI 1641,

50 O. W. Szold r s ki: Historla s. 195-197.

51 A Adm. Vol. 20 (1704) S. 533-534.

52 Zob. przyp. 48 (1706).

53 Catalogus documentorum $1850 \mathrm{nr} 19$ (reg.).

54 ADT: Fasc. Tuchów (kopla z końca XVI w.). - Catalogus documentorum 1850 nr 175 (reg.).

55 Suplika pospolstwa $z$ XVIII w. s. 2.

56 Tamze. - ADT' Fasc. Tuchów.

57 LBD, III s. 222 . - A. K a r b o w a k, jw. Cz. 2 s. 42.

58 Por. Kot: "Szkolnıctwo s. $176 \mathrm{n}$. (Nie zna wizyt. 1748).

59 O. W. S z ołd rski, jw. s. 198-201. - ADT: Fasc. Benedyktyni w Tuchowie (kopia z. XVIII w.).

60 A Adm. Vol. 20 (1704) s. 533-534.

61 Zob. przyp. $59-60$.

62 Por. O. W. Szołdrs ki, jw

As Tamze $s$, 17 ? 
co potwierdził 27 VI 1642 bp krak. sufr. Tomasz Oborski, uznając tym samym obraz NMP za łaskami słynacy ${ }^{64}$. Wiz. 1748 podaje obszerny inwentarz wotów, zawieszonych przy obrazie ${ }^{65}$.

\section{PARAFIA W IER Z CHOSEA W I E (wieś)}

Źródla przekrojowe: MPV, I i II (1325-1358); Gromnicki: Swiętopietrze s. 364 n. $(1328-1358,1373-1374,1551)$; LBD, I s. 422, II s. 308, III s. 197; LR 1513 k. 20: LR 1527 k. 42; LR 1529 s. 123; Rej. pob. 1536 s. 552; LR 1539 k. 20'; LR 1561 k. 97' LR 1577 k. 86; Rej. pob. 1581 s. 263; Wiz. 1596 k. $15^{\prime}-17$; Syn. 1621 s. 28; Wiz. 1637 k. $374^{\prime}-375$, Starowolski 1655 k. $\mathrm{E}_{3}{ }^{\prime}$; Wiz. 1664 s. 512-515, 550-552; Wiz. 1665 s. 19-20; Wiz. 1669 k. 24-25; Syn. 1711 s. 15; Wiz. 1748 k. 57-64.

Inne źródla: ADT: 1. Fasc. Wierzchosławice (or. i kop. XV-XIX w.); 2. Jura et erectiones praebendae in Wierzchosławice (z XVIII w.); 3. Inventarium ecclesiae parochialis in Wierzchoslawice a. D. 1813; 4. Index documentorum huic phylurae adclusorum - - 1876. - Bibl. Ossol. Sygn. 11613/IrI: Wodzicki Piotr, kasztelan sądecki - - Rachunki klucza Wierzchosławice z r. 1765.

W ażniejsze op racowania: F. Herzig: Katedra s. 40-44. - Kumor: Zanik i afiliacja s. 110 .

I A. Parafia, fundacji rycerskiej, powstała prawdopodobnie w pierwszej połowie XIII w. ${ }^{1}$; pierwsza wzmianka w r. 1325. 20 II 1481 wieś z prawem patronatu przeszła tytułem zakupu na własność Jana Amora Tarnowskiego?. 22 I 1494 Jan Amor z Tarnowa, w celu udotowania nowej prebendy kanonickiej p.w. św Barbary przy kolegiacie tarnowskiej, inkorporowal beneficjum parafialne do tejże prebendy; w miejsce zniesionej parafii utworzono "wikarię wieczysta", której zlecono curam animarum ${ }^{3}$. 28 IV 1498 tenże Tarnowski wydał podobny dokument inkorporacyjny, co potwierdził 19 XII 1498 kard. Fryderyk Jagiellończyk, bp krak., który erygował w miejsce parafii ,wikarię wieczysta" ${ }^{4}$ (Por. Tarnów - parafia Nawiedzenia NMP $L_{1-4}$ ). W $\mathrm{r}$ 1786, po zniesieniu kolegiaty tarnowskiej, kościołowi przywrócono prawa parafialne ${ }^{5}$

Patronat: szlachecki ${ }^{6}$.

I B. Okręg parafialny ${ }^{7}$ w r. $1498-1536$ obejmowal: Wierzchosławice, Ostrów, Gosławice, Komorów oraz Bogumiłowice. W r. 1581 brak dwóch ostatnich wsi, ale wymieniono nadto: Rudki i Bogumiłowice. W r. 1596 zostały wyliczone: Wierzchosławice, Bogumiłowice, Ostrów, Komorów, Gosławice i ,polowa Rudki". W r 1664 występuje jeszcze Wola Wierzchosławicka.

I C. Ludność parafii $w$ połowie XIV $w$ szacuje się na 330 osób $^{8}$. W r. 1637 do komunii wielkanocnej przystapiło 800 wiernych. W r. $1664-$

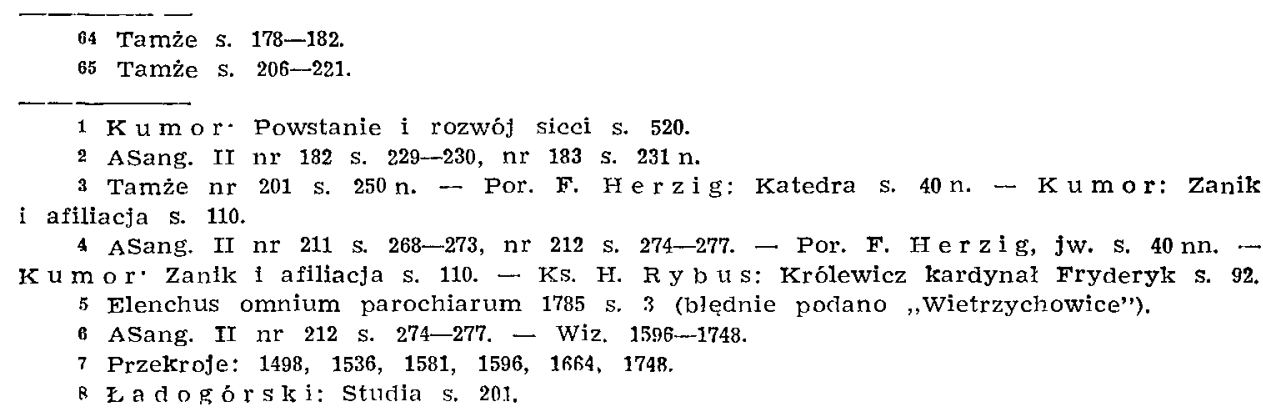


lącznie 816 osób, w tym z Wierzchosławic - 147, z Woli Wierzchosławickiej - 155, Ostrowia - 86, Bogumilowic - 168, Rudki - 80, Komorowa 94 i Gosławic - 86.

I D. Kościól parafialny, wzmiankowany w latach 1325-1358, był za czasów Długosza „drewniany i poświęcony”. W latach 1596-1637 „drewniany i konsekrowany". W czasie wojen kozackich (1648-1656) został spalony ${ }^{\circ}$. W r. 1664 nowy, również drewniany ,był w budowie”. Konsekrował go w r. 1669 bp sufr. krak. Tomasz Oborski ${ }^{10}$. Wr. 1747 ks. Franciszek Gargulowicz dobudował don kaplicę murowaną p. w. M. B. Pocieszenia ${ }^{11}$. W r. 1748 „kościół był drewniany i konsekrowany”. 30 IV 1797 „kościół _spłonął"; nowy, murowany zaczęto budować w r. $1812^{12}$.

Wezwanie: św. Wajciecha b. i $\mathrm{m}^{13}$.

I F. Wierzchosławice. Szpital parafialny istniał przed r. 1498; 19 XII 1498 kard. Fryderyk Jagiellończyk zobowiązuje parafian ,naprawić rozpadający się stary szpital i nowy zbudować" ${ }^{14}$. W r. 1596 , ,szpital stojący obok kościoła, byl w stanie dobrym, uposażenia nie posiadał żadnego". W r. 1664 "budynek szpitalny, będący w stanie dobrym, posiadał 2 komory". 9 IX 1678 szpital otrzymal legat ${ }^{15}$. W r. 1748 ,szpital po większej części potrzebował naprawy". W r. 1664 w szpitalu mieszkało 7 ubogich.

I G. Wierzchosławice. Bractwo IV. B. Pocieszenia zostało zaprowadzone w 1747 r., za zgodą gen. zakonu augustianów Leona a Juventu (12 XII 1739) i oficjała krakowskiego (16 II 1740) ${ }^{16}$. 12 XII 1753 otrzymało ono własnego kapelana ${ }^{17}$. Inne wzmianki: $1758,1791^{18}$. (Por. $\mathrm{I} \mathrm{M}_{1}$ ).

I H. Szkoła parafialna, wzmiankowana pierwszy raz w r. $1498^{10}$, była w r. 1596 ,w stanie niezbyt dobrym". Inne wzmianki: 1527, 1637, 1539, $1665^{20}$. Istniała jeszcze w r. $1813^{21}$.

I M. Wierzchosławice. Prebendę dla promotora bractwa M. B. Pocieszenia uposażył 29 X 1748 ks. Antoni Gargulowicz, ,wikariusz wieczysty" w Wierzchosławicach, zapisujac na ten cel 6000 zł pol. Erygował ją 12 XII 1753 bp krak. Andrzej Stanisław Załuski ${ }^{22}$. $25 \times 1757$ uposażenie prebendy zostało powiększone o dalszy legat w wysokości 1000 zł pol.,3; 12 VI 1758

9 Wiz. 1664 S. 550: ,ecclesia - - per cosacos est igne consumpta".

10 Wiz. 1669--1748.

11 Wiz. 1748.

12 Inventarium 1813 s. 1.

13 LBD, II $\mathrm{s}$, 308. — ASang. II $\mathrm{nr} 211-212$ s. 268-277. - Wiz. 1596-1748. - Elenchus omnium parochiarum $1785 \mathrm{nr}$ 3. - Nowy koscioł murowany został konsekrowany w 1824 r. przez bpa tyn. G. T. zieglera. - Zob. Schematismus 1863 s. 31.

14 zob. przyp. 6.

15 Wiz. 1748 s. 63 (reg.).

16 Wiz. 1748 (reg. obydwu dokumentów).

17 Jura et erectiones nr 1 (kopia). - Index documentorum $1876 \mathrm{nr} 1$ (reg.).

18 ADT. Fasc. Wierzchoslawice (kopia dokum. $z$ r. 1758). - Index documentorum nr 2 (1791).

19 Zob. przyp. 4.

20 Por. K o t: Szkolnictwo s. $318 \mathrm{n}$.

21 Inventarium 1813 s. 1.

22 AEp. Vol. 90 (1753-1754) k. 190-198. - Jura et erectiones nr 1 (kopie z XVIII w.). Index documentorum nr 1 porlate date 12 II 1748 ,

$\$ 3$ Tamze nr 2 (kopia z XVIIT w.). 
Feliks Niemojewski legował nadto 1000 zł pol. ${ }^{24}$. 9 VIII i 22 VIII 1791 bp tarn. Florian Amand Janowski zniósł prebendę, a jej uposażenie wcielił do beneficjum parafialnego w Wierzchosławicach ${ }^{25}$.

Patronat: fundatora ${ }^{\mathbf{2 6}}$.

\section{PARAFIA ZALASOWA (wieś)}

Zródła przekrojowe: LBD, I s. 605, 609: III s. 200; Rej. pob. 1508 s. 466; LR 1513 k. 22'; LR 1527 k. 47'; LR 1529 s. 106; Rej. pob. 1536 s. 551; LR 1539 k. 22; Gromnicki: Swiętopietrze s. 366 n. (1551-1562); LR 1561 k. 34; LR 1577 k. 84'; Rej. pob. 1581 s. 264 ; Wiz. 1596 k. $10^{\prime}-12$; Syn. 1621 s. 28 ; Wiz. 1637 k. 373 ; Starowolski 1655 k. $E_{3}{ }^{\prime}$; Wiz. 1664 s. 489-490, 534; Wiz. 1665 s. 9-10; Wiz. 1669 k. 1-2; Syn. 1711 s. 15 ; Wiz. 1748 k. 40-44.

Inne źró d la: ADT: 1. Fasc. Zalasowa (or. i kop. z XVIII i XIX w.); 2. Fasc. "Akta 1791". - APar. w Zalasowej: Liber memorabilium ecclesiae paroch. in Zalasowa (z pierwszej polowy XIX w.). - Bibl. Ossol. Sygn. 2272/II: Acta iudicii bannitii Zaliassoviensis $1506-1635$.

I A. 22 VI 1362 część wsi Zalasowa przeszła, tytułem zakupu, w ręce Leliwitów - Tarnowskich ${ }^{1}$.

Parafia, fundacji rycerskiej, powstala pod koniec w. XIV ${ }^{2}$; pierwsza wzmianka z r. $1416^{3}$. Rzekomy dokument fundacyjny parafii z 1342, wystawiony przez Janusza Działyńskiego, księcia na Ostrogu, jest falsyfikatem ${ }^{4} 20$ VII 1593 ks. Janusz Ostrogski wyraził zgodę na inkorporacje beneficjum parafii do uposażenia kolegium wikariuszy tarnowskich i utworzenia w miejsce parafii "wikarii wieczystej". 9 III 1594 kard. Jerzy Radziwiłl, bp krak., dokonał włączenia beneficjum i erekcji "wikarii wieczystej" 5. 16 IV 1791 parafia otrzymała swe dawne, pełne prawa ${ }^{6}$.

Patronat: szlachecki; od 1594 kolegium wikariuszy kolegiaty tarnowskiej; od 1791 ponownie szlachecki ${ }^{7}$.

I B. Okręg parafialny ${ }^{8}$ w latach 1536-1581-1596-1664 obejmował tylko wieś Zalasowe. W r. 1748 wymieniono nadto: Wymys? (późn. Wymyśle), Wytaruch i Wólka Zalasowska.

I C. W r. 1536 mieszkało w parafii $36 \mathrm{kmieci}$, a w 1581 - 70 kolonów, 9 zagrodników, 36 inquilini, 20 ubogich, 2 rzemieślników i 9 innych ludzi. W r. 1596 w parafii było $70 \mathrm{kmieci}$. W r. 1664 do komunii wielkanocnej przystąpiło 712 osób.

I D. Kościół parafialny, wzmiankowany w 1. $1416^{\circ}$, był w Jatach 1596 -

24 ADT: Fasc. Wierzchosławice (kopia z 1784 r.).

25 Tamze (oryg. dokum. pap.). - Index documentorum nr 2 (reg.).

26 Zob. przyp. 22.

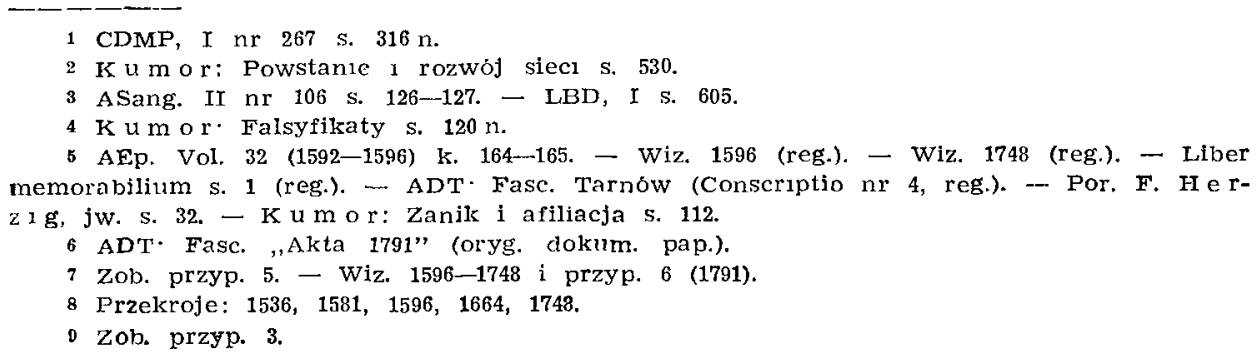


1637-1664, „drewniany i konsekrowany”. W r. 1748 dodano, że ,został zbudowany na fundamentach dębowych".

Wezwanie: św. Jan Apost. i Ewang. ${ }^{10}$.

I H. Szkoła parafialna w r. 1596 ,była w stanie lichym, nowy budynek w budowie". W r. 1664 wizytator zalecił proboszczowi większą ,pilność około wprawiania młodzieży w naukach i śpiewie"; w r 1669 polecil „napomnieć parafian, by swoich synów posyłali doıszkoły na kształcenie w naukach i śpiewie" $"$.

\section{PARAFIA ZASSÓW (wieś)}

Źródła przekrojowe: MPV, II (1346-1358); Gromnicki: Swiętopietrze s. 372 n. $(1346-1358,1373-1374,1551-1558)$, LBD, I s. 15 ; II s. $259,260,437,438$; Rej. pob. 1508 s. 466 , LR 1513 k. 65'; LR 1527 k. 151; LR 1529 s. 92, 99; Rej. pob. 1536 s. 552-554; LR 1539 k. 55, LR 1561 k. 57-57'; LR 1577 k. 106'; Rej. pob. 1581 s. 247; Wiz. 1596 k. 4'-7; Syn. 1621 s. 28; 1637 k. $372^{\prime}-373$; Starowolski 1655

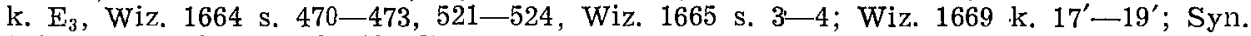
1711 s. 15 ; Wiz. 1748 k. $18-27$.

Inne źródła: ADT: 1. Fasc. Zassów (or. i kop. XVI-XIX w.); 2. Liber documentorum ecclesiae in Zassów (sprzed $1770 \mathrm{r}$.); 3 . Conspectus fundatarum missarum et aliarum devotionum ecclesiae paroch. in Zassów a. D. 1868.

I A. W r. 1291 Władysław Łokietek nadał wieś ,Zassow" Klemensowi, synowi Wawrzyńca !

Parafia, fundacji rycerskiej, powstała przed r. $1344^{2}$; pierwsza wzmianka z r. $1344^{3}$.

Patronat: szlachecki ${ }^{4}$.

I B. Okręg parafialny ${ }^{5}$ za czasów Długosza obejmował wsie: Zassów, Wiewiórka, Borowa, Róża i Jaźwiny. W r. 1536 wymieniono nadto: Mokre, Korzeniów, Wolica i Nagoszyn. W r. 1581 do parafii należały: Zassów, Dulcza Wielka, Zdziarzec, Zdżar, Mokre, Wiewiórka, Borowa, Róża, Czarna, Jaźwiny, Dąbie, Dulcza Mała, Dąbrówka, Przeryty Bór i Jastrząbka. 31 III 1599 kard. Jerzy Radziwiłł wyłączył z niniejszego okręgu parafię Jastrzabka. (Zob. Jastrząbka). W r. 1581 Stefan Batory zezwolił Mikołajowi Firlejowi na zalożenie miasta Radomyśla Wielkiego na gruntach wsi Ruda i Dulcza, a 7 VII 1599 kard. Jerzy Radziwiłł erygowal tu niezależna parafię ". W r. 1596 i 1664 w granicach parafii znajdowały się wsie: Zassów, Mokre, Wiewiórka, Borowa, Róża, Jaźwiny, Czarna, Przeryty Bór, Dąbie i Dąbrówka. W r. 1748 wymieniono jeszcze Jawornik.

I C. W połowie XIV w. ludność parafii szacuje się na 150 osób?. W r. 1596 zaznaczono, że ,wszystkie wioski parafialne są bardzo ludne". W r. 1664 do komunii wielkanocnej przystapiło łącznie z całej parafii 2122

10 Wiz. 1596-1748. - Elenchus omnium parochiarum 1785 nr 16.

11 Por. K o t: Szkolnictwo s. $\mathbf{3 1 5 .}$

\footnotetext{
1 CDPol. I nr 78 s. 142 n. - Por. K. Potk á́s k i: Kraków przed piastami s. 193.

2 K u m or: Powstanie I rozwój sieci s. 526.

3 MPV, II s. 198 (J. Ptaśnik ldentyfikuje ja z Rzeszowem).

4 AOffic. Vol. 1 (1436-1453) pod datą: 16, 25 V; 5 i 17 IX, 2 X 1453 (spór o prawa patronack1e). - LBD. - Wiz. 1596-1748.

5 Przekroje; 1470, 1536, 1581, 1596, 1664, 1748.

$6 \mathrm{~K}$ u m or: Archidiakonat. T. 9 s. 156.

$?$ Ła d o gór ss i: Studia s. 208.
} 
osoby, z czego z Zassowa - 225, Mokrego - 124, Wiewiórki - 334, Róży 387, Borowej - 278, Przerytego Boru - 70, Dąbia - 237, Dąbrówki - 197, Czarnej - 88 i Jaźwin - 152. W r. 1721 w całej parafii mieszkało 3000 wiernych ${ }^{8}$. W r. 1748 do komunii wielkanocnej przystąpiły 2433 osoby.

I D. Kościół parafialny, wzmiankowany już w 1344 r., był za czasów Długosza "drewniany i konsekrowany". Przed r. 1596, „ze względu na wielką ilość wiernych", do świątyni została dobudowana drewniana kaplica p. w. św. Stanisława b. i m.; obydwie części były "drewniane i konsekrowane". W r. 1637 był tu „kościól drewniany, bardzo okazały”. W latach 1664-1669 był „drewniany i konsekrowany". W r. 1721 wizytator polecił "dać nowy dach na cały kościół" 9. W r. 1748 był „kościół drewniany, na fundamentach murowanych, dawnej budowy".

Wezwanie: św. Klemens p. i m. $(1470,1596,1785){ }^{10}$; św. Wojciech b. i m. (1637); św. Klemens p. 1 m. oraz św. Stanisław b. i m. (1596, 1664, 1669, $1748)$.

I E. Wiewiórka. Kaplica drewniana p. w. św. Katarzyny p. i m. została wybudowana przed r. 1547; 28 X 1547 została konsekrowana ${ }^{11}$. W roku 1664 była w stanie dobrym. W r. 1748 „w większej części w stanie zniszczonym, zwłaszcza odnośnie okien i dachu".

I F. Zassów. Szpital istnial tu. przed r. 1575. Nowy szpital zbudowali i 8 IV 1575 uposażyli ,karczmą nowozbudowaną na zagrodzie - - 2 grzywnami" i innymi naturaliami Jan Kostka ze Stangeburga, wojew. malborski i podskarbi ziemi pruskiej, oraz Zofia ze Sprowy Kostczyna, dziedziczka dóbr Wiewiórka ${ }^{12}$. W latach 1596-1664-1669-1748 budynek szpitalny był w stanie dobrym. W r. 1664 mieszlkalo w nim 11 ubogich.

I G. Zassów. Bractwo Różańca św. zostało zaprowadzone w r. $1662^{13}$. 7 XI 1712 bp krak. Kazimierz Eubieński erygował dwie kapelanie brackie. (Por. $\mathrm{M}_{3}$ i $\mathrm{M}_{4}$ ). Inne wzmianki: $1664,1669,1721,1748^{14}$

I H. Zassów. Szkoła parafialna w r. 1596 ,była połączona ze szpitalem pod jednym dachem”. W r. 1665 ,kierownik szkoły utrzymuje kantora dla kształcenia młodzieży $w$ nauce; ten jednak nie wielu ma chłopców, chodzących do szkoły, bo zaledwie 4, ale spodziewa się, że więcej ich będzie w zimie". W r. 1721 wizytator polecil proboszczowi, by ,budynek szkolny pokrył i naprawił oraz utrzymywał zdolnego bakałarza, który by nauczał chłopców literatury i śpiewru kościelnego" ${ }^{15}$. W r. 1748 szkoła jeszcze istniała. Inne wzmianki: $1637^{16}$.

I $\mathrm{M}_{1}$. Zassów. Prebenda fundi Zassów, uposażona ,jednym łanem”, zapewne przez Tenczyńskich, przed r. 1470. Inne wzmianki: 1470, 1513, 1527,

8 Liber documentorum 1770 s. 73 (Decretum reformationis pro ecclesia paroch. in Zassów 9 VIII 172I).

9 Liber documentorum 1770 s. 73.

10 Elenchus omnitum parochiarum $1785 \mathrm{nr} 44$.

11 wiz. 1664 s. 522 (reg.).

12 Liber documentorum 1770 s. 1-2 (kopia). - ADT: Fasc. Zassów (kopia z XVIII w.). Conspectus $1868 \mathrm{nr} 26$ (reg.). - Wiz. 1748 (reg.).

13 Wiz. 1664 s. 523 .

14 Liber documentorum 1770 s. 73.

15 Tamże.

16 Por. Kot: Szkolnıctwo s. 313. 
$1529,1539,1561,1577,1596,1637$. W latach $1637-1664$ została ona inkorporowana do prebendy fundi Jaźwiny ${ }^{17}$.

Patronat: szlachecki ${ }^{18}$.

I $\mathrm{M}_{2}$. Prebenda fundi Jaźwiny p. w. św. Klemensa p. i m., została uposażona w $1497 \mathrm{r}$. przez Barbarę z Rożnowa ${ }^{19}$. (Zob. I $\mathrm{M}_{1}$ ). Inne wzmianki: $1664,1669,1721,1748^{20}$.

Patronat: szlachecki ${ }^{21}$.

I $\mathrm{M}_{3}$. Prebendę I dla kapelana bractwa Różańca św. uposażył 2 XI 1665 ks. Grzegorz Chruszczyna, kanon. tarn. i proboszcz zassowski, przeznaczając na ten cel (lącznie z prebendą II) 7000 zI pol. 22 XI 1711 fundacja została wykończona pod względem prawnym (ks. Ostrogski) ${ }^{22}, 7$ XI 1712 bp krak. Kazimierz Łubieński zatwierdził fundację i erygował prebende ${ }^{23}$. 6 IX 1728 ks. Jan Natkański, archidiakon tarn. i proboszcz zassowski legował na rzecz prebendy I i II $2000 \mathrm{zI}$ pol. ${ }^{24}$ Inne wzmianki: 1748. (Por. I G).

Patronat: szlachecki ${ }^{25}$.

I $\mathrm{M}_{4}$. Zassów. Prebendę II dla drugiego kapelana bractwa Różańca św. uposażył 2 XI 1665 ks. Grzegorz Chruszczyna, legując na ten cel (łącznie $z$ prebendą I) 7000 zł pol. 22 XI 1711 fundacja została doprowadzona do końca pod względem prawnym (ks. Ostrogski). 7 XI 1712 bp krak. Kazimierz Łubieński zatwierdził fundację i erygował prebendę. 6 IX $1728 \mathrm{ks}$. Jan Natlkański zapisał na rzecz prebendy I i II 2000 zł pol. Inna wzmianka: 1748. (Por. I $\mathrm{M}_{3}$ ).

Patronat: szlachecki.

I N. Zassów. Easkami słynący obraz M. B. Rózáńcowej był tu przed 1677. 23 IX 1677 uczyniono legat na fundacje ,lamp przed łaskami słynącym obrazem" ${ }^{26}$. Inna wzmianka: $1698^{27}$.

\section{PARAFIA ZD ZI A R Z E C (wieś)}

Źródła przekrojowe: MPV, I i II (1325-1328, 1350-1355); Gromnicki: Swiętopietrze s. 372 n. $(1328,1373-1374,1551-1560,1563)$; LBD, I s. 15, II s. 293; LR 1513 k. 63'; LR 1527 k. 147'; LR 1529 (brak); Rej. pob. 1536 s. 503; LR 1539 k. 54; LR 1561 (brak); Rej. pob. 1581 s. 247, 254; Wiz. 1596 k. 3'-4'; Syn. 1621 s. 28; Wiz. 1637 k. $372-373$; Starowolski 1655 k. $E_{3}^{\prime}$; Wiz. 1664 s. 473-475, 524-525; Wiz. 1665 s. $4-5$; Wiz. 1669 k. 16'-17'; Syn. 1711; Wiz. 1748 k. $12-17$.

Inne źródla: ADT: 1. Fasc. Zdziarzec (or. i kop. XVI-XIX w.); 2. Inventarium ecclesiae parochialis in Zdziarzec 1799. W: Collectio inventariorum decanatus Radomyslensis 1799-1814; 3. Kircheninventar der Pfarrkirche $\mathrm{zu}$ Zdziarzec 1813 (Fasc. Beneficia 1813); 4. Status personalis ecclesiae paroch. in Zdziarzec tempore visitationis descriptus a. D. 1814. W: Collectio, jw.

17 Wiz. 1637 wymienıa 2 prebendy; Wiz. 1664 tylko jedna. Wiz. 1721 s. 72 : „Prebendarius fundi Zassów et Jaźwiny"'. Inne przekazy wskazują, ze stało się to w r. 1697. - Zob. Liber documentorum 1770 , s. 20.

18 Por. Wiz. 1596.

10 Liber documentorum 1770 s. 29 (dokum. z 1697). - Wiz. 1748 k. 21' (reg.).

20 Liber documentorum 1770 S. 72 (1721)

21 Por. Wiz. 1596.

22 Liber documentorum 1770 s. 73 (reg.), 112--117, 117-123, 123-133.

28 AEp. Vol. 75 (1710-1713) k. 52C-527. - Wiz. 1748 k. 21' (reg.).

24 AOffic. Vol. $169(1727-1728)$ s. $719-724$.

25 Zob. przyp. 22-23.

26 Liber documentorum 1770 s. 30 .

2. Tamże. 
I A. Parafia, fundacji rycerskiej, powstała przed r. 1328; pierwsza wzmianka $z$ r. $1328^{\prime}$. Rzekomy dokument fundacyjny parafii z 28 IX 1320 , wystawiony przez Petrazjusza Ligęzę, jest falsyfikatem ${ }^{2}$. Długosz $w$ jednym przekazie informuje o istnieniu w Z. samodzielnej parafii ${ }^{3}$, w drugim zaś zalicza tę wieś do parafii Rzochów ${ }^{4}$. W latach 1513-1539 parafia jest znów samodzielna ${ }^{5}$. W r. 1581 zaliczona do parafii Zassów. (Zob. Zassów I B). W latach 1596-1785 parafia znowu była samodzielną. 4 X 1785 Gubernium Lwowskie postanowiło inkorporować parafię do Radomyśla W., ale na przedłożenie proboszcza z 27 IX 1785 została ona zamieniona na kapelanię lokalną ${ }^{6}$.

Patronat: szlachecki ${ }^{7}$.

I B. Okręg parafialny ${ }^{8}$ w r. 1596 obejmował wsie: Zdziarzec, Zdziar, Mała Dulcza i Wielka Dulcza ${ }^{\circ}$. W latach 1664-1748-1814 do parafii należały: Zdziarzec, Zdziarówka i DuIcza Wielka.

I C. Dla połowy XIV w. ludność parafii szacuje się na 285 osób ${ }^{10}$. W r. 1664 do komunii wielkanocnej przystąpiło łącznie 806 wiernych, w tym z. miejscowości Zdziarzec - 223, Zdziarówka - 302 i Dulcza Wielka - 281. W 1748 r. - 1200 osób, a w 1814 r. — 2783 osoby ${ }^{11}$.

I D. Kościół parafialny, wzmiankowany w 1350 r., był w latach 15961637-1664, „drewniany i konsekrowany". W r. 1748 zaznaczono, że ,zbudowany na fundamentach dębowych został konsekrowany w 1673".

Wezwanie: św. Marcin b. i w. ${ }^{12}$.

I F. Zdziarzec. Szpital, „zbudowany na gruncie plebańskim, zamieszkiwało w 1748 r. 6 ubogich". W r. 1814 ,dom szpitalny miał w sobie dwie izby" ${ }^{13}$. Inne wzmianki: $1799^{14}$.

I H. Zdziarzec. Szkoła parafialna posiadała w 1596 r. „dom świeżo postawiony"; ,poprzedni kierownik szkoly - - utrzymywał się z jałmużny”. Inne wzmianki: $1637,1665,1669^{15}$.

I Kumor: Powstane I rozwoj sieci s. 526. - MPV, I s. 157 (plebanus ecclesiae de Zarecz),

2 K u m or. Falsyfikaty s. 121.

3 LBD, II s. 293 .

4 LBD, I s. 15 ,

5 AOffic. Vol. 33 (1512-1517) s. 727-728. - Por. K u mor: Archidiakonat. T. S, 159.

- ADT. Fasc. Zdziarzec (oryg. dokum. pap.).

7 Wiz. 1596-1748. - Inventarium 1799 s. 1.

8 Przekroje: 1596, 1664, 1748, 1814 (Status 1814).

9 Gromnickl (Swiętopletrze s. 373) podaje, ze do parafii przed r. 1563 należała wleś Zgórsko.

10 É a d ogór ski: Studia s. 208.

11 Status 1814 s. 1.

12 Wiz. 1596-1748. - Elenchus ommum parochırum $1785 \mathrm{nr} 36$.

13 zob. przyp. 11.

14 Inventarium 1799 s. 1.

13 Por. Kot: Szkolnictwo s. $313 \mathrm{n}$. 
DE PRAEPOSITURA TARNOVIENSI. COMMENTATIO RERUM A MONUMENTIS PETITARUM AD ATLANTEM HISTORICUM ECCLESIAE IN POLONIA LUCUBRANDUM

S u m m a rium

Istud studium, habita ratione propositorum in dissertatione, cui index Archidiaconatus Sandeciensis, delineatam praebet descriptionem quorumvis institutorum socialium atque ecclesiasticorum, quae intra fines Praepositurae Tannoviensis erant in ambitu latinarum paroeciarum eisdem ipsis annexis. Quae hoc studio tenentur, ascendunt ad XII saeculum descenduntque ad annos $1772 / 1786$, quo tempore Austria, captam a se partem dioecesis Cracoviensis, dioecesim Tarnoviensem, Tarnoviae sedem habentem, fecerat. Res, quae hoc studio proponuntur, spectant in primis ad instituta cclesiae Latinae, deinde Ecclesiae Protestantium necnon religıonis Mosarcae, sed tantum in finibus paroeciarum latinarum; in ambitu enim Praepositurae Tarnoviensis nulla erant instituta Ecclesiae Orientalis, tam catholicae quam schismaticae.

Si documenta spectes Praepositurae, sunt quası elus fundamenta monumenta historica ecclesiastica (Archivum Curıe et Capituli Metropolitani Cracoviensis, Archivum Dioecesanum Tarnoviense singulaque archiva paroecialia), tum fontes civitatıs publici (Publicum Civitatis Archivum Palatınatus Cracoviensis, Museum Urbis Tarnoviae, Publicum Institutum Ossolineum Vratıslaviense). Praestantiores lam adhibiti fontes typisque publicati praeter alios sunt: indices oboli s. Petrı atque Sanctae Sedis decimae, beneficiorum libr dioecesis Cracoviensis, documentorum notitiae ex diplomaticıs aliisque codicibus depromptae, typis expressi elenchi in militiam delectorum, synodales catalogi paroeciarum aliique. Schema in describendis paroeciis applicatum 14 varia elementa affert, idemque est ac quod in dissertatione Archidiaconatus Sandeciensis adhibitum erat.

Integrum hoc studium duabus partibus constat. Quarum pars prima, quae est prooemium, disserit de temperatione maioris ordinis, quae facta est in finibus Praepositurae (praepositura, officialatus, decanatus); altera vero, quae praebet medullam succumque rei, confert ordine ad litteram digesto adumbratam descriptionem paroeciarum eodemque etiam cursu religıosa et socialia instituta ibi vigentia.

Praeposituram Tarnoviensem, utpote iurisdictionis regionem ad instar archidiaconatus, Adalbertus Jastrzębiec episcopus Cracovıensis 9 mensis maii anno 1416 erexit, atque 6 paroecias ad decanatum Tarnoviensem attinentes de archidiaconatu Cracoviensi exemit (Skrzyszów, Szynwald, Zalasowa, Poręba Radlna, Lisia Góra et Eękawica) et dicioni praepositı collegialis templi Tarnoviensis subegit. Praepositurae fines augentur, nam 12 maii 1542 a. Petrus Gamrat episcopus 3 paroecias (Wierzchosławice, Zassów, Zdziarzec), anno 1616 Petrus Tylicki episcopus 7 alias paroecias (Jurków, Góra Zbylitowska, Jodłówka, Pleśna, Piotrkowice, Tuchów, Ryglice), die 11 decembris 1686 a. Ioannes Małachowski episcopus paroeciann Luszowice, a. 1711 Casimirus Eubieński episcopus paroecias Dąbrowa Tarnowska et Radgoszcz eiusdem dicioni adiunxerunt.

Praeterea Tarnovia non solum sedes erat templi collegialis et praepositurae sed etiam viri officialis districtus in dioecesi Cracoviensi. Cuius officialatus initium inter annos 1416-1500 ponendum est. Officialatus vero fines apposite finibus Praepositurae congruebant. Qui officialatus limites post annum 1772 magis protrahuntur, ab anno autem 1781 Tarnovia fit sedes officialatus generalis "Gallicianae" parti dioecesis Cracoviensis.

Ad originem decanatus Tarnoviensis quod attinet duae diversae dantur opiniones, quarum altera ab auctore huius studii orta tenet, eius primordia saeculo XII quaerenda esse, altera dicit saeculo XIII exstitisse tantum decanatum Voiniciensem, non autem Tarnoviensem, viderique eundem intra annos 1470-1513 ortum esse. 
Pars altera describit 23 paroecias, quae in finibus Praepositurae ab saeculo XII ad XVIII exsistebant; quarum paroeciarum 2 prorsus disparuerunt (Tarmovia: S. Martínus et $\mathbf{S}$. Maria in Castro), 5 ceterae mutatae sunt in vicarias perpetuas (Wierzchosławice, Skrzyszów, Eękawica, Zalasowa, Poręba Radina), 1 anno 1400 collegiatae dignitate aucta est (Tarnovia: Nativitas B.M.V.).

Inter 19 templa paroeciarum, quae erant in Praepositura anno 1596, duo templa fuerunt latericıa, cetera lignea; anno autem 1748 - quattuor (Tarnów, Eękawica, Lisia Góra, Tuchów). Paene apud omnes paroecias hae pie fraternitates erant: Corporis Christi, Sanctıssimae Trinitatis, S. Rosarii, S. Scapularis, Litteratorum B.M.V., Consolationis B.M.V., Immaculatae Conceptionis B.M.V., S. Annae, S. Ioseph, S. Franciscı, S. Antonii de Padua, S. Ioannis Nepomuceni, Lazari Pauperumque. Saeculo XVI et XVII scholae paroeciales omnibus paroeciis erant, saeculo autem XVIII tantummodo 10 earum habuerunt. Praeterea Tarnoviae initio schola collegialis erat, a saeculo XVIII Colonia Academica Universitatis Cracoviensis manebat, et XVII saeculo ad coenobium PP. Bernardinorum studium philosophicum vigebat.

In 4 paroeciis imagines gratiis ditatae inveniebartur. Praebendae atque altariae fraquentissima erant instituta. Praeterea in territorio Praepositurae erant 2 protestantium fana (Góra Zbylitowska, Jodłówka), 2 Iudaeorum synagogae (Dąbrowa Tarnowska, Tarnów) atque 1 protestantium schola (Szczepanowice).

\section{SPIS RZECZY}

Przedmowa

Bibliografia załącznilkowa i skróty

Wstęp: Prepozytura, oficjalat i dekanat tarnowski.

1. Powstanie, obszar 1 granice prepozytury tarnowskiej . . . [10]

2. Powstanie, rozwój i zniesienie okręgowego oficjałatu tarnowskiego

3. Dekanat tarnowski

Parafia Dąbrowa Tarnowska (miasto) . . . . . . . . [19]

" Góra Zbylitowska . . . . . . . . . . . . . [21]

" Jastrząbka . . . . . . . . . . . . . . [24]

" Jodłówka (Szczepanowice) . . . . . . . . . . . . [25]

" Jurków (Łęg Tarnowski) . . . . . . . . . . . $[27]$

" Lisia Góra

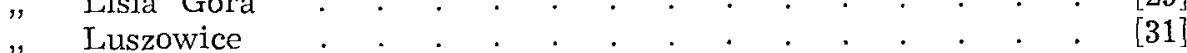

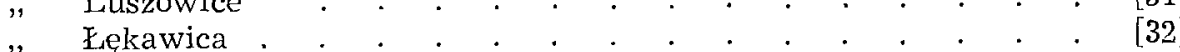

Piotrkowice

Pleśna

Poręba Radlna

Radgoszcz

Ryglice

Skrzyszów

Szynwałd 
Tarnów (miasto) - parafia św. Marcina . . . . . . . . . [ [45]

Tarnów (miasto) - parafia Wniebowzięcia NMP . . . . [46]

Tarnów (miasto) - parafia Narodzenia NMP . . . . . [48]

Parafia Tuchów (miasto) . . . . . . . . . . . . . . . [69]

$"$ Wierzchosławice . . . . . . . . . [75]

" Zalasowa . . . . . . . . . . . . [77]

" Zassów $\quad . \quad . \quad . \quad . \quad . \quad$. . . . . . . . . . .

"Zdziarzec . . . . . . . . . . . . . . . . 480$\}$

Summarium . . . . . . . . . . . . . . . . . [82]

(C. d. n.) 